Historic, Archive Document

Do not assume content reflects current scientific knowledge, policies, or practices. 
<smiles>C1CCCCC1</smiles> 


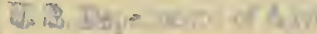

The Bay State Nurseries

WINDSOR H. WYMAN, Proprietor

North Abington, Massachusetts

\section{PRICE LIST SPRING 1921}

The prices in this list cancel those in all previous lists.

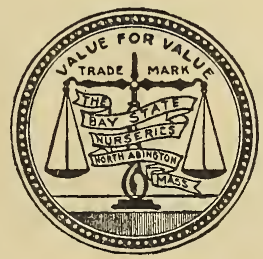

INDEX

\begin{tabular}{|c|c|c|c|}
\hline Terms and Condition & & & \\
\hline Deciduous Trees & . & $\cdot$ & • \\
\hline Deciduous Shrubs & - & - & - \\
\hline Evergreen Trees & . & . & . \\
\hline Evergreen Shrubs & . & - & • \\
\hline Fruit Trees & . & . & - \\
\hline Fruits, Small & - & - & - \\
\hline Perennials & . & - & - \\
\hline Rhododendrons & - & - & - \\
\hline Roses . . & . & & • \\
\hline Vines and Climbers & & & \\
\hline
\end{tabular}

Long Distance Telephone, Rockland 26.

Telegraphic Address, North Abington, Mass. 


\section{THE PLANTING SEASON}

Transplanting can be done successfully as soon as the frost is out of the ground in the spring until early in June. Evergreens and herbaceous perennials can be successfully transplanted until the middle of June. We usually begin to dig about the 20th of March.

\section{Directions for Shipping}

Desties ordering are requested to state explicitly the mode of conveyance by which they desire their stock forwarded.

When no route is designated, we exercise our judgment; but in no case do we assume any responsibility after packages are shipped, unless for our own mistakes. When losses occur by detention, claims should at once be made on the TRANSPORTATION COMPANY by the consignee.

\section{INSPECTOR'S CERTIFICATE ACCOMPANIES EVERY SHIPMENT.}

\section{CONDITIONS OF SALE}

First-The articles herein listed will be furnished at prices designated as per following schedule:

1 to 5 plants of one kind will be charged for at the single rate, whatever the aggregate of a list made up in numbers of less than 5 . plants of a specific sort may be.

5 to 40 plants of one kind will be furnished at the ten rate.

40 to 250 plants of one kind will be furnished at the hundred rate when hundred rates are given except in the case of perennials when 25 of one kind will be given the hundred rate.

250 plants and above of one kind are entitled to the thousand rate when a thousand rate is given.

FROM THIS SCHEDULE WE WILL NOT VARY because of the fact that it takes considerable time to assemble a list of plants that are scattered over the nursery.

Second-We give no warranty, expressed or implied, as to quality, description, productiveness, or any other matter of any nursery stock that we sell. No complaints will be considered that are not made within ten days after receipt of stock.

Third-The prices annexed do not include the boxes or bales. A charge for the actual cost of the boxes or the material used in baling is made. No charge for conveyance to freight station.

Our terms are cash, unless by special agreement. We can ship by express, C. O. D., when desired, with charges for collection added to the bill-provided 20 per cent of the amount of the order accompanies the same as a guarantee. Said guarantee will be required only from parties with whom we have no business acquaintance. All bills remaining unpaid December 1 st in Fall, and June 1st in Spring, will be subject to sight draft without further notice.

BAY STATE NURSERIES, 


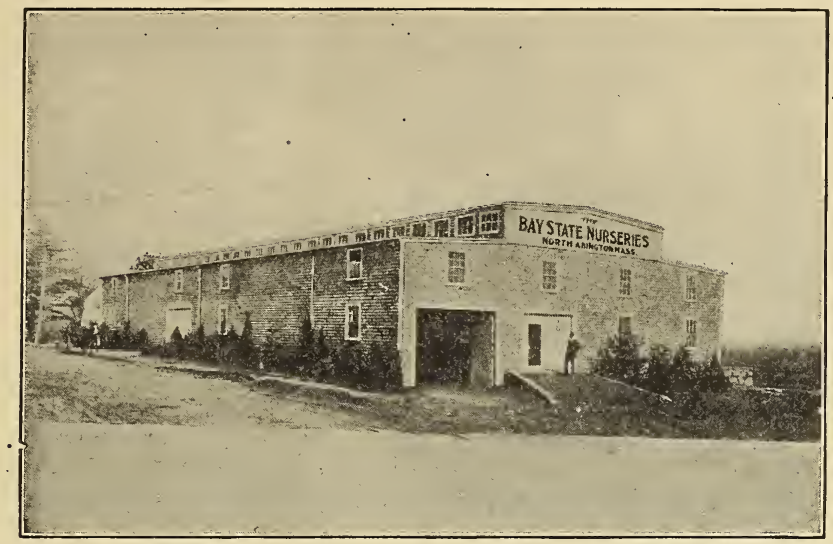

Packing House Adjoining Railroad Siding

\section{Ornamental Department}

NOTE - In compiling this list, we have endeavored to include only such varieties of stock as we have now in our nurseries, in sizes and quantities offered. In filling orders we shall grade stock according to these specifications. Should orders be received for sizes not found in this list, or should any specified grade be exhausted, we will send the nearest size we have in stock at the time the order is received and charge accordingly; UNLESS OTHERWISE ADVISED.

\section{DECIDUOUS TREES}

ACER campestre

Each Per 10

Per 100

ACER campestre English Cork-bark Maple

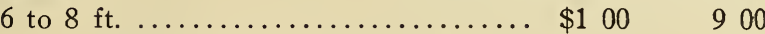

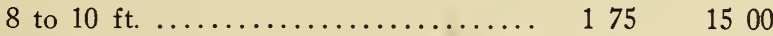
12000

10 to 12 ft. ..................... $250 \quad 2200$

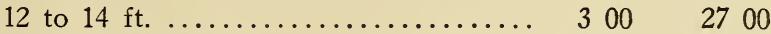

\section{dasycarpum (saccharinum) Silver Maple}

12 to $14 \mathrm{ft}$., $13 / 4$ to $2 \mathrm{in.} \mathrm{............} 200 \quad 1800$

12 to $14 \mathrm{ft} ., 2$ to $2 \frac{1}{2}$ in. ............. $250 \quad 2200$

15 to $20 \mathrm{ft}$., $2 \frac{1}{2}$ to $4 \mathrm{in}$. specimens $\$ 500$ to 1500 var. wieri

Wier's Cut-leaved Maple

8 to $10 \mathrm{ft}$

$175 \quad 1600$

10 to 12

$225 \quad 2000$

12 to $14 \mathrm{ft}$

$260 \quad 2500$

22500

14 to $16 \mathrm{ft}$

300

2700

negundo

Ash-leaved Maple

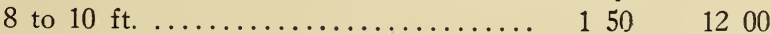

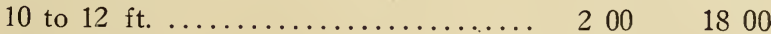

15000

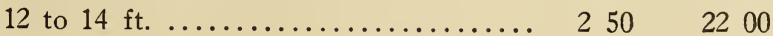


ACER - continued

Each Per 10 Per 100

platanoides

Norway Maple

8 to $10 \mathrm{ft} ., 1$ to $1 \mathrm{r} / 4$ in. ............. 150

$1400 \quad 12000$

10 to $12 \mathrm{ft}, 1 \mathrm{r} / 4$ to $1 \mathrm{I} / 2 \mathrm{in} . \ldots \ldots \ldots \ldots$. 200

$1800 \quad 16000$

12 to $14 \mathrm{ft} ., 11 / 2$ to $13 / 4$ in............ 250

$2200 \quad 20000$

12 to $16 \mathrm{ft} ., 13 / 4$ to 2 in. ............ 300

$2800 \quad 25000$

12 to $16 \mathrm{ft} ., 2$ to $2 \mathrm{r} / 2$ in. ............. 400

3600

30000

$2 \mathrm{r} / 2$ to $3 \mathrm{in}$.

500

3 to 4 in. specimens..........\$10 00 to 2000

$4500 \quad 40000$

Large sizes in car lots at special prices.

p. var. reitenbachi

Reitenbach's Purple Maple

6 to $8 \mathrm{ft} . \ldots \ldots \ldots \ldots \ldots \ldots \ldots . \ldots . \ldots 200 \quad 1800$

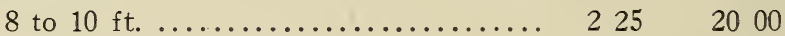

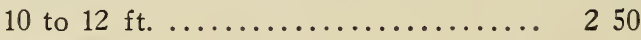

p. var. schwedleri

Schwedler's Purple Maple

6 to $8 \mathrm{ft}$.

$180 \quad 1600$

8 to $10 \mathrm{ft}$

$220 \quad 2000$

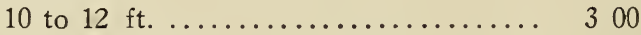

12 to $14 \mathrm{ft} .2$ to $3 \mathrm{in} . \ldots \ldots \ldots \ldots \ldots .400$

palmatum

Japanese Maple

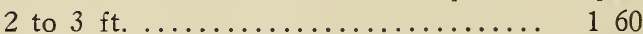

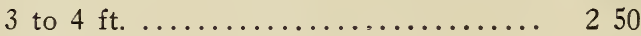

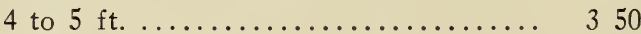

5 to $6 \mathrm{ft}$. specimens .............. 500

p. var. atropurpureum

Blood-leaved Jap. Maple

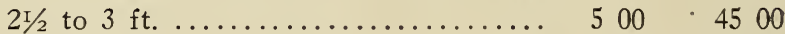

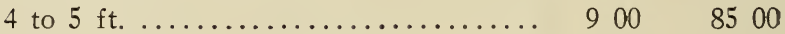

5 to $6 \mathrm{ft}$. bushy specimens .......... 1200

$6 \mathrm{ft}$. bushy specimens ............. 2500

p. var. dissectum

Cut-leaved Jap. Maple

$2 \mathrm{ft}$. spread ................... 350

$2 \mathrm{I} / 2$ to $3 \mathrm{ft}$. spread $\ldots \ldots \ldots \ldots \ldots \ldots \ldots$ 4 450

3 to $4 \mathrm{ft}$. spread ............... 600

pseudoplatanus

Sycamore Maple

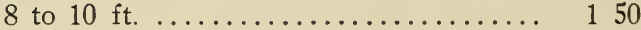

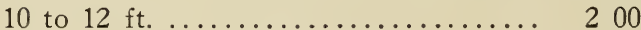

$1400 \quad 12500$

12 to $14 \mathrm{ft} . \ldots \ldots \ldots \ldots \ldots \ldots \ldots \ldots \ldots, 300 \quad 2500 \quad 20000$

p. p. var. purpurascens

Purple-leaved Sicamore Maple

8 to $10 \mathrm{ft}$

$200 \quad 1800$

10 to $12 \mathrm{ft}$.

250

rubrum

Red or Scarlet Maple

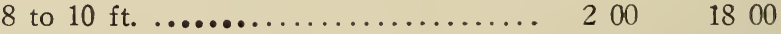

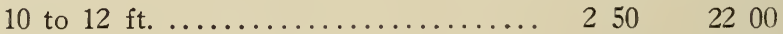

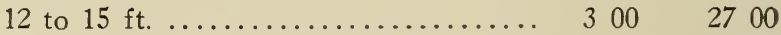


ACER - continued

saccharum
Each Per 10 Per 100

Sugar or Rock Maple

8 to $10 \mathrm{ft} ., 1$ to $1 \mathrm{x} / 4$ in................ $150 \quad 1400 \quad 12000$

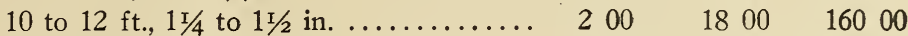

12 to $14 \mathrm{ft} ., 1 \mathrm{r} / 2$ to $13 / 4$ in. ............ $250 \quad 2200 \quad 20000$

14 to $16 \mathrm{ft}, 13 / 4$ to 2 in. ................ $300 \quad 2800 \quad 25000$

14 to $16 \mathrm{ft}$., 2 to $2 \mathrm{r} / 2$ in. ........... $400 \quad 3800 \quad 32000$

15 to $18 \mathrm{ft}$., $2 \frac{1}{2}$ to $3 \mathrm{in}$., $\$ 500$ to $\$ 700$ according to size and quality. 3 to $3 \mathrm{r} / 2$ in. ........ $\$ 1000$ to $\$ 1500$

Larger specimens....... from $\$ 1500$ to 3000

spicatum

Mountain Maple

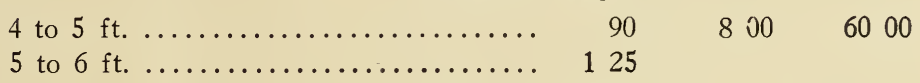

tataricum

Tatarian Maple

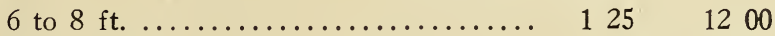

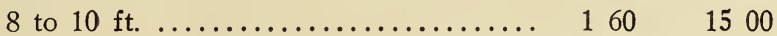

var. ginnala

Siberian Maple

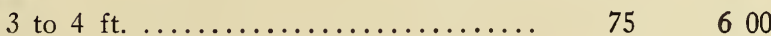

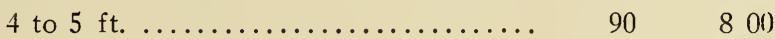

7500

5 to $6 \mathrm{ft} . \ldots \ldots \ldots \ldots \ldots \ldots \ldots \ldots \ldots \ldots, 120 \quad 1100$

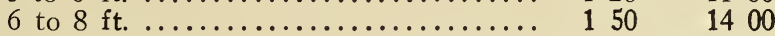

9000

AESCULUS hippocastanum

European Horse Chestnut

6 to $8 \mathrm{ft}$

$225 \quad 2000$

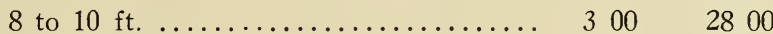

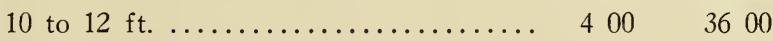

$2 \mathrm{I} / 2$ to 3 in. specimens $\ldots \ldots \ldots \ldots \ldots \ldots, 500$

3 to 4 in. specimens ............... 1000

h. var. alba flora plena

Dble. White Horse Chestnut

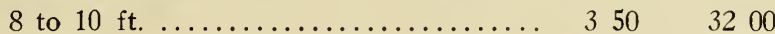

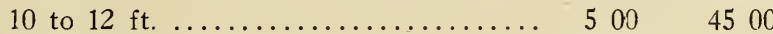

12 to $14 \mathrm{ft} . \ldots \ldots \ldots \ldots \ldots \ldots \ldots \ldots \ldots, 600$

parviflora

Dwarf Horse Chestnut

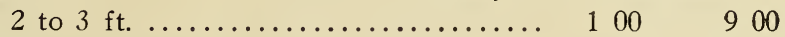

AILANTHUS glandulosa Tree of Heaven

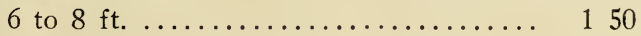

\section{ALNUS glutinosa Black Alder}

8 to $10 \mathrm{ft}$.

120

$1000 \quad 8000$

incana

Speckled Alder

10 to 12 ft. ................... $150 \quad 1400$

ARALIA spinosa

Hercules Club

\begin{tabular}{|c|c|}
\hline to $6 \mathrm{ft} . \ldots \ldots \ldots \ldots \ldots$ & 120 \\
\hline ft. ... & 150 \\
\hline $10 \mathrm{ft} . \ldots \ldots \ldots \ldots \ldots \ldots \ldots \ldots \ldots \ldots \ldots$ & 200 \\
\hline
\end{tabular}




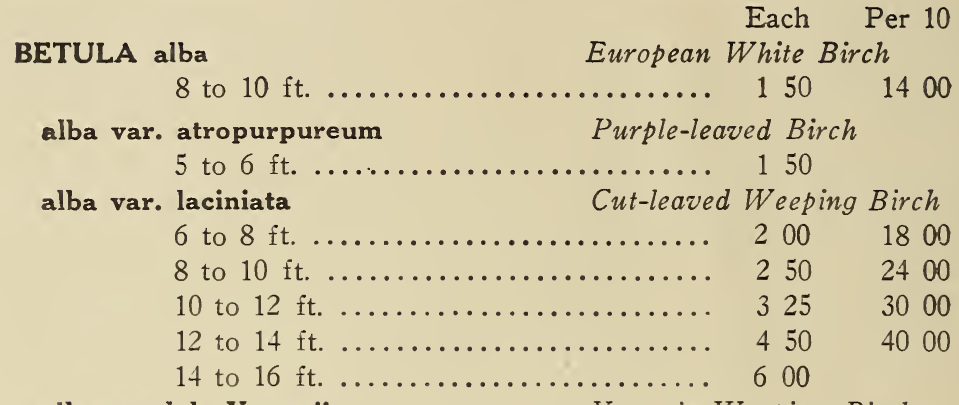

alba pendula Youngii Young's Weeping Birch

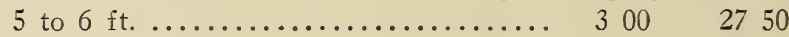

6 to $8 \mathrm{ft} . \ldots \ldots \ldots \ldots \ldots \ldots \ldots \ldots \ldots, 400$

lenta

Black Birch

10 to $12 \mathrm{ft} . \ldots \ldots \ldots \ldots \ldots \ldots \ldots \ldots \ldots .200 \quad 1800$

16000

12 to $14 \mathrm{ft}$.

Yellow Birch

lutea

$225 \quad 2100$

20000

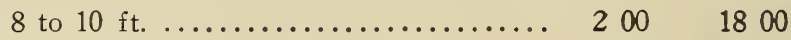

10 to $12 \mathrm{ft} . \ldots \ldots \ldots \ldots \ldots \ldots \ldots \ldots .225 \quad 2100$

papyrifera

Paper or Canoe Birch

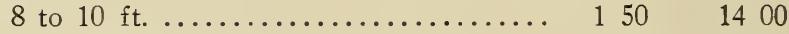

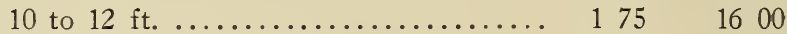

15000

12 to $14 \mathrm{ft}$.

$250 \quad 2200$

populifolia

American Gray Birch

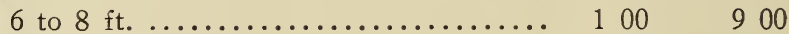

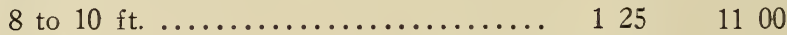

rubra or nigra

Red or River Birch

8 to $10 \mathrm{ft} . \ldots \ldots \ldots \ldots \ldots \ldots \ldots \ldots \ldots . \ldots 200 \quad 1800$

10 to $12 \mathrm{ft} . \ldots \ldots \ldots \ldots \ldots \ldots \ldots \ldots \ldots .2400$

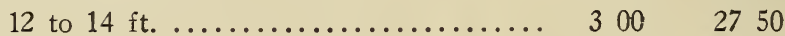

18000

14 to $16 \mathrm{ft} . \ldots \ldots \ldots \ldots \ldots \ldots \ldots \ldots . \ldots \ldots$. $350 \quad 3200$

CARPINUS betulus

European Hornbeam

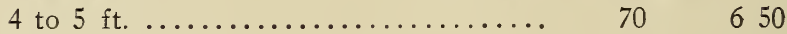

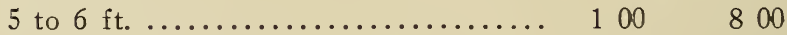

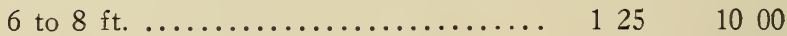

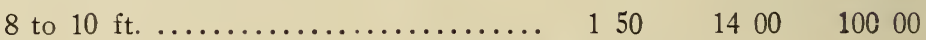

caroliniana

American Hornbeam

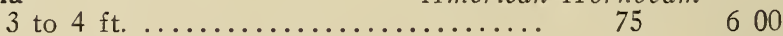

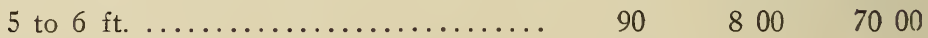

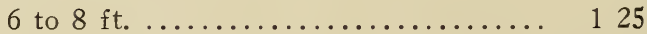

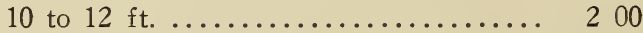

CATALPA bungei

Umbrella Catalpa

2 yr. heads ..................... 250

$3 \mathrm{yr}$. heads

Japanese Catalpa

10 to $12 \mathrm{ft}$.

12 to $14 \mathrm{ft}$

250 


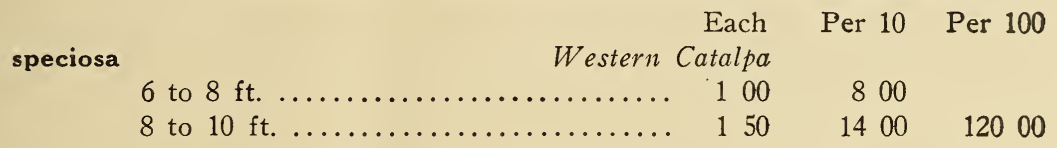

CELTIS occidentalis

Nettle Tree

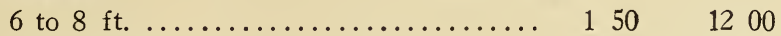

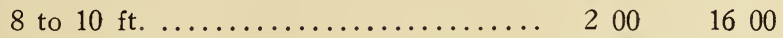

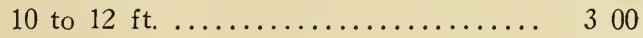

CERASUS avium flora plena

8 to $10 \mathrm{ft}$.

Dble. White Flowering Cherry

jap. rosea fl. pl.

4 to $5 \mathrm{ft}$

.

500

Red Flowering Cherry

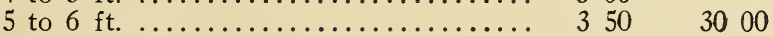

var. Sherofugan (white)

White Flowering Cherry

5 to $6 \mathrm{ft}$. 400

CERCIDIPHYLIUM japonicum ........Kadsura Tree

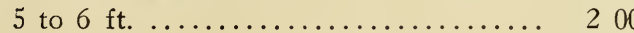

1500

6 to $8 \mathrm{ft}$

300.2800

8 to $10 \mathrm{ft}$.

$400 \quad 3600$

10 to $12 \mathrm{ft}$.

$500 \quad 4500$

32000

40000

CERCIS canadensis

2 to $3 \mathrm{ft}$.

Red Bud or Judas Tree

3 to $4 \mathrm{ft}$.

$60 \quad 500$

5 to $6 \mathrm{ft}$

$90 \quad 800$

6 to $8 \mathrm{ft}$.

$150 \quad 1400$

$200 \quad 1800$

CHIONANTHUS virginica

White Fringe

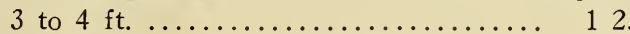

1000

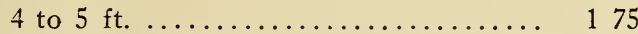

1500

5 to $6 \mathrm{ft}$. bushy .................. $225 \quad 2000$

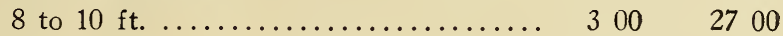

CLADRASTIS tinctoria Yellow Wood

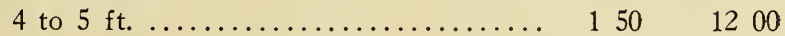

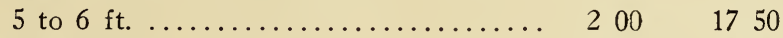

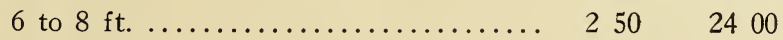

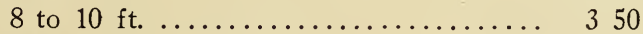

CORNUS florida

White Flowering Dogwood

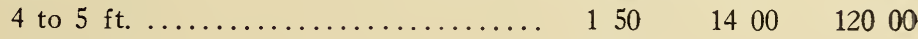

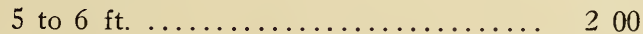

f. var. rubra

Red Flowering Dogwood

3 to $4 \mathrm{ft}$.

200

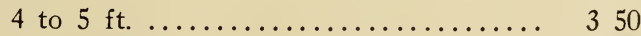

3200

5 to $6 \cdot \mathrm{ft}$

500

4500

6 to $7 \mathrm{ft}$. specimens B. \& B.

700

6500 
CRATAEGUS carrieri

Each

Per 10 Per 100

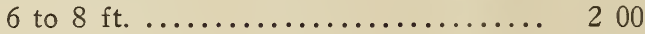

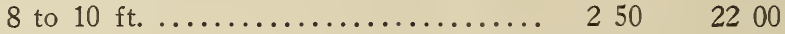

coccinea

Scarlet Thorn

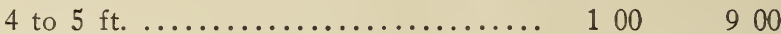

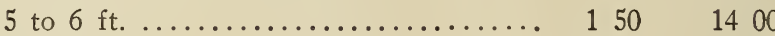

12000

6 to $8 \mathrm{ft} . \ldots \ldots \ldots \ldots \ldots \ldots \ldots \ldots \ldots . \ldots 200 \quad 1800$

cordata Washington Thorn

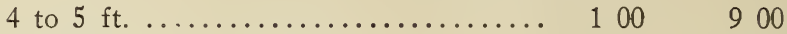

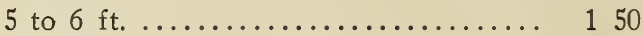

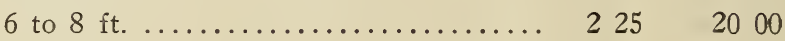

crus-galli $\quad$ Cockspur Thorn

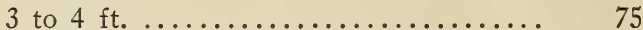

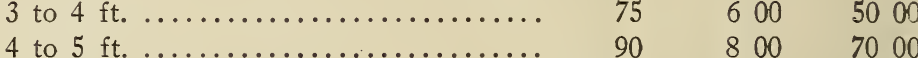

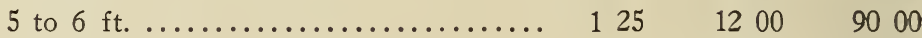

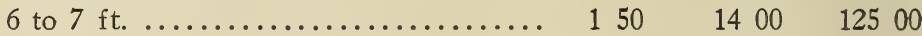

mollis

Scarlet Hawthorn

5 to $6 \mathrm{ft} . \ldots \ldots \ldots \ldots \ldots \ldots \ldots . \ldots . \ldots . \ldots 150 \quad 1400$

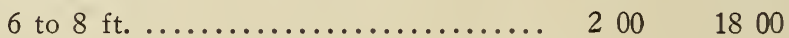

oxycantha

Common Hawthorn

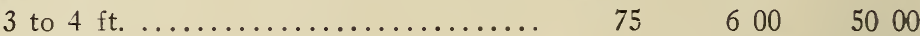

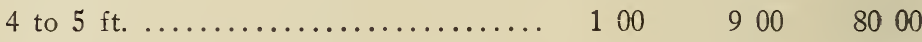

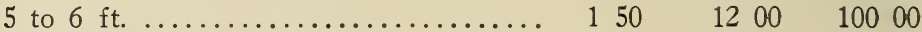

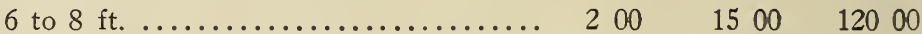

oxy. var. flora plena Pauli Paul's Dble. Scarlet Thorn

4 to $5 \mathrm{ft} . \ldots \ldots \ldots \ldots \ldots \ldots \ldots . \ldots . \ldots 200 \quad 1800$

oxy. var. flora alba plena Double White Hawthorn

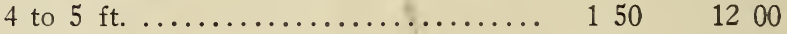

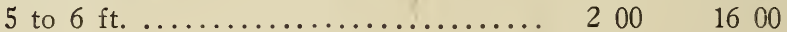

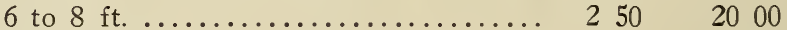

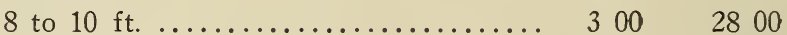

10 to $12 \mathrm{ft} . \ldots \ldots \ldots \ldots \ldots \ldots \ldots \ldots \ldots, 400 \quad 3600$

DIRCA palustris

Leatherwood

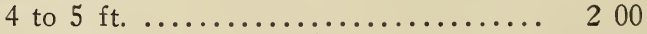

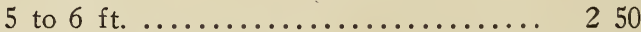

FAGUS americana (grandifolia) American Beech

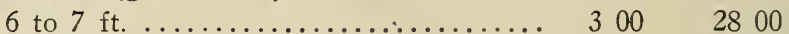

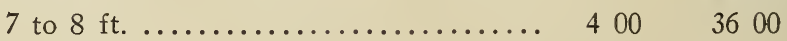

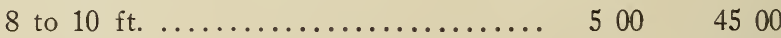

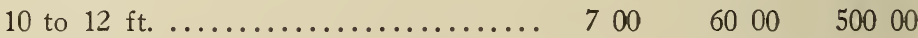

sylvatica

European Beech

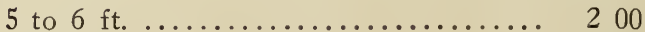

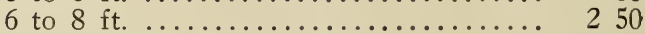

1800

$2200 \quad 20000$

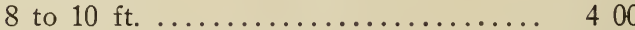

$3600 \quad 30000$

10 to $12 \mathrm{ft}$. specimens .............6 $600 \quad 5000 \quad 40000$ 
FAGUS - continued

Each

Per 10 Per 100

s. var. asplenifolia

Fern-leaved Beech

5 to $6 \mathrm{ft}$. specimens ............... 500

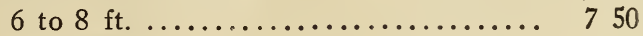

s. var. heterophylla

Cut-leaved Beech

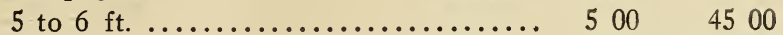

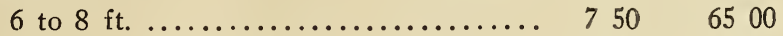

8 to $10 \mathrm{ft}$. specimens .............. $1000 \quad 9000$

8. var. pendula

European Wpg. Beech

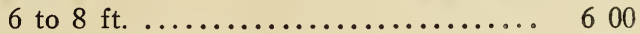

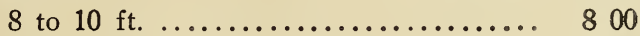

10 to $12 \mathrm{ft} . \ldots \ldots \ldots \ldots \ldots \ldots \ldots \ldots \ldots, 1000$

8. var. purpurea Purple Beech

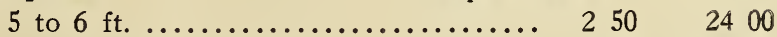

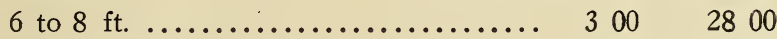

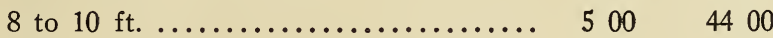

10 to $12 \mathrm{ft} . \ldots \ldots \ldots \ldots \ldots \ldots \ldots \ldots \ldots, 700 \quad 6000$

s. var. riversii

River's Purple Beech

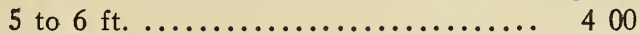

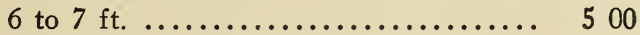

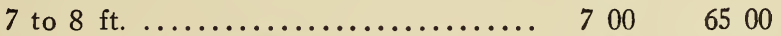

8 to $10 \mathrm{ft}$. specimens ............. 1000

10 to $12 \mathrm{ft}$. specimens ............ 1500

FRAXINUS americana American White Ash

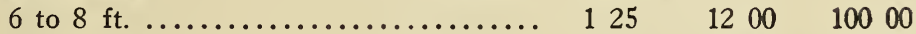

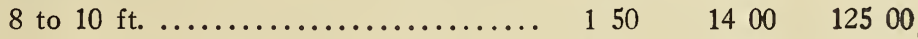

6 to 8 ft......................... $125 \quad 1200$

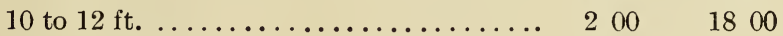

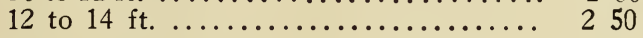

lanceolata

Green Ash

8 to $10 \mathrm{ft} . \ldots \ldots \ldots \ldots \ldots \ldots \ldots \ldots \ldots \ldots \ldots \ldots \ldots \ldots \ldots \ldots \ldots \ldots \ldots$

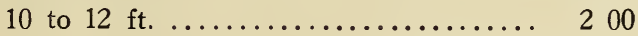

nigra

Black Ash

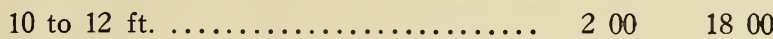

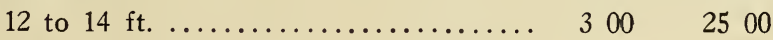

GINKGO biloba

Maidenhair Tree

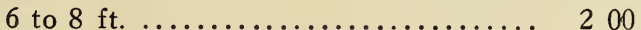

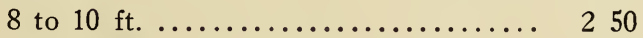

$1800 \quad 16000$

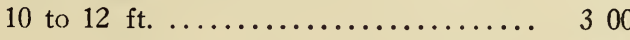

$2200 \quad 20000$

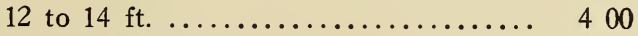

GLEDITSCHIA triacanthos

Honey Locust

3 to $4 \mathrm{ft} . \ldots \ldots \ldots \ldots \ldots \ldots \ldots \ldots \ldots \ldots \ldots \ldots \ldots \ldots \ldots \ldots \ldots \ldots \ldots \ldots$

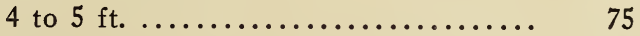

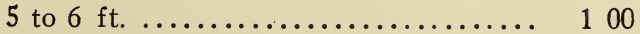

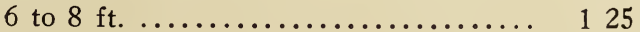

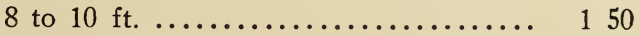


Each Per 10 Per 100

GYMNOCLADUS canadensis

Kentucky Coffee Tree

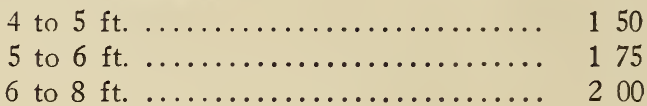

JUGLANS cinerea

Butternut

6 to $8 \mathrm{ft}$.

200

1800

KOELREUTERIA paniculata

5 to $6 \mathrm{ft}$.

Varnish Tree

$200 \quad 1800$

LABURNUM vulgare

Golden Chain Tree

6 to $8 \mathrm{ft}$.

225

2000

LARIX europea

European Larch

5 to $6 \mathrm{ft} . \ldots \ldots \ldots \ldots \ldots \ldots \ldots . \ldots . \ldots . \ldots 200$

1800

6 to $8 \mathrm{ft}$.

250

2200

8 to $10 \mathrm{ft}$

300

2500

18000

10 to $12 \mathrm{ft}$

400

22500

leptolepsis syn. kaempferi

10 to $12 \mathrm{ft}$.

Japanese Larch

12 to $14 \mathrm{ft} . \ldots \ldots \ldots \ldots \ldots \ldots \ldots \ldots . .500$

\section{LINDEN (See Tilia)}

LIQUIDAMBAR styraciflua Swect Gum

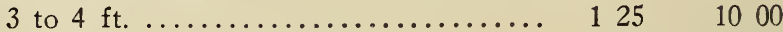

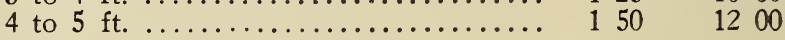

LIRIODENDRON tulipifera Tulip Tree

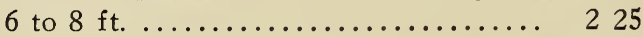

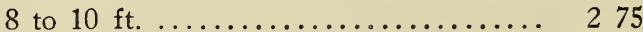

MAGNOLIA alexandrina Alexander's Magnolia

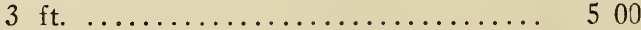

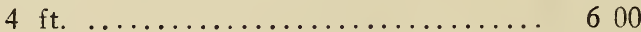

glauca

Sweet Magnolia

3 to $4 \mathrm{ft}$.

400

soulangeana

Soulange's Magnolia

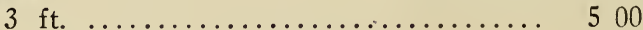

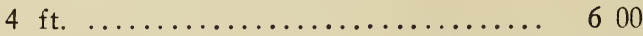

speciosa

Show'y-fiowered Magnolia

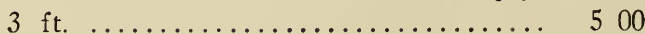

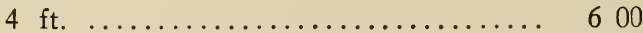

stellata

Hall's Magnolia

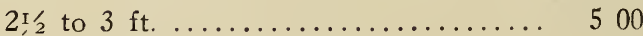

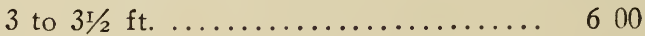

$3 \mathrm{r} / 2$ to $4 \mathrm{ft} . \ldots \ldots \ldots \ldots \ldots \ldots \ldots \ldots \ldots \ldots \ldots \ldots \ldots$

yulan (conspicua)

Chinese White Magnolia

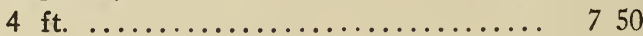


MALUS (Pyrus)

angustifolia

Each Per 10

Per 100

Bechtel's Flowering Crab

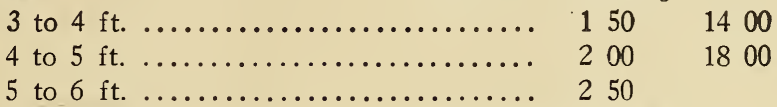

coronaria

Sweet-scented Crab

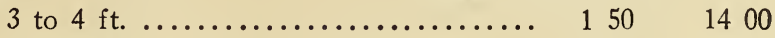

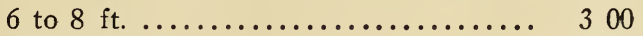

8 to $10 \mathrm{ft} . \ldots \ldots \ldots \ldots \ldots \ldots \ldots \ldots . \ldots \ldots, 400$

floribunda

Flowering $\mathrm{Crab}$

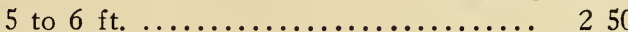

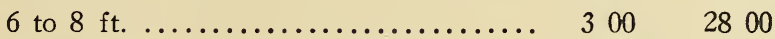

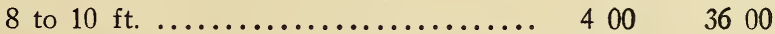

var. atrosanguines

150

1400

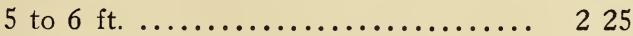

2000

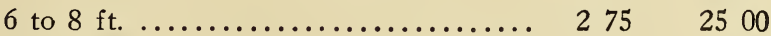

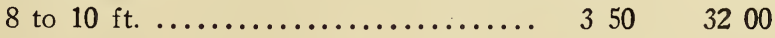

niedzwetzkyana

Pink Siberian Crab

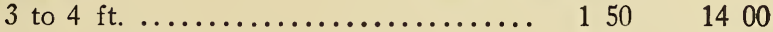

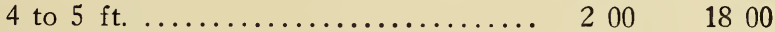

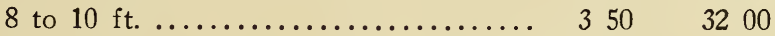

parkmanni

Parkman's Crab

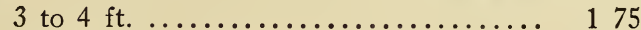

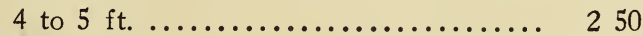

scheideckeri

Double-flowering Crab

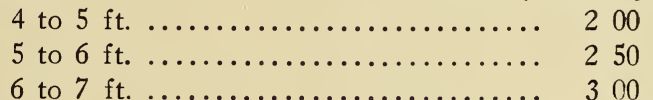

spectabilis

Chinese Crab

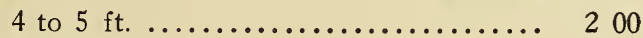

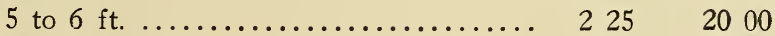

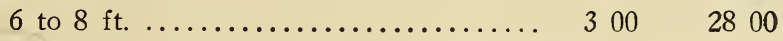

MORUS alba

White Mulberry

5 to $6 \mathrm{ft} . \ldots \ldots \ldots \ldots \ldots \ldots \ldots \ldots . \ldots 200 \quad 1800$

var. pendula

Tea's Weeping Mulberry

$1 \mathrm{yr}$. heads ..................... 250

2 yr. heads ..................... 300

var. tatarica rubra

Red Russian Mulberry

4 to $5 \mathrm{ft}$.

$125 \quad 1000$

MOUNTAIN ASH (See Sorbus)

OXYDENDRON arboreum

Sorrel Tree

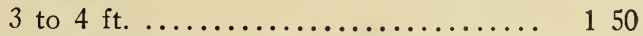

PAVIA MACROSTACHYA (See Aesculus parviflora)

PERSICA plena (red, pink and white) Dble. Flowering Peach

5 to $6 \mathrm{ft} . \ldots \ldots \ldots \ldots \ldots \ldots \ldots . \ldots \ldots$ 
PHELLODENDRON amurense Amoor Cork Tree

6 to $8 \mathrm{ft} . \ldots \ldots \ldots \ldots \ldots \ldots \ldots \ldots \ldots 250 \quad 2200$

PLATANUS acerifolia (orientalis) Oriental Plane Tree

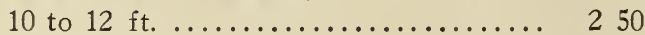

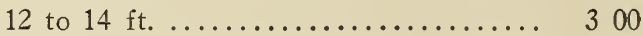

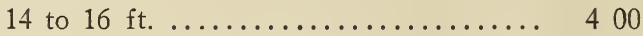

POPULUS balsamifera Balsam or Balm of Gilead 8 to $10 \mathrm{ft} . \ldots \ldots \ldots \ldots \ldots . \ldots . \ldots . \ldots 250$

canescens Gray Poplar

18 to $25 \mathrm{ft} . \ldots \ldots \ldots \ldots$ from $\$ 500$ to 700

deltoides var. monolifera Carolina Poplar

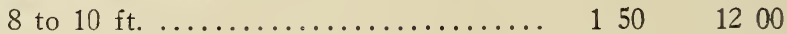

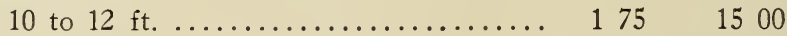

nigra var. italica (fastigiata) Lombardy Poplar

6 to $8 \mathrm{ft} . \ldots \ldots \ldots \ldots \ldots \ldots \ldots \ldots \ldots . \ldots \ldots$. $125 \quad 1100 \quad 9000$

8 to 10 ft............................. $150 \quad 1250 \quad 10000$

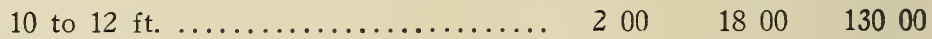

12 to $14 \mathrm{ft} .1 \mathrm{t} / 2$ to 2 in. ........... $250 \quad 2000 \quad 15000$

PRUNUS pissardi Purple-leaved Plum

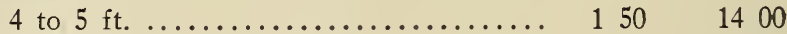

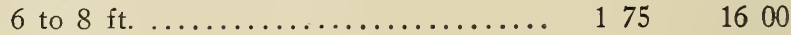

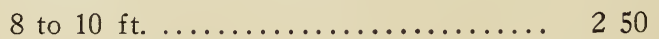

PTELEA trifoliata Hop Tree

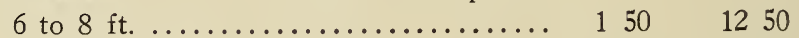

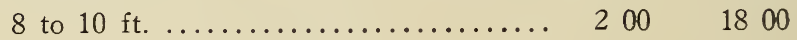

PYRUS (See Malus)

QUERCUS alba White Oak

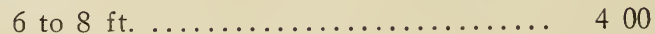

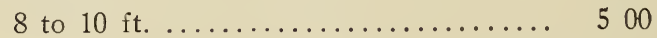

bicolor

Swamp W'hite Oak

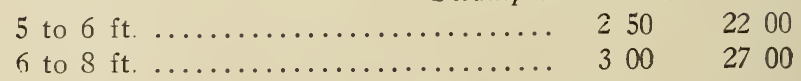

coccinea

Scarlet Oak

6 to $8 \mathrm{ft} . \ldots \ldots \ldots \ldots \ldots \ldots \ldots \ldots \ldots \ldots$

macrocarpa Mossy Cup Oak

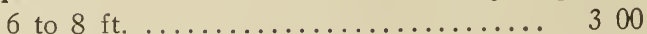

8 to $10 \mathrm{ft} . \ldots \ldots \ldots \ldots \ldots \ldots \ldots \ldots, 400$ 
QUERCUS alba - continued

Each Per 10 Per 100

palustris

Pin Oak

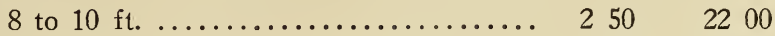

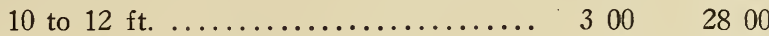

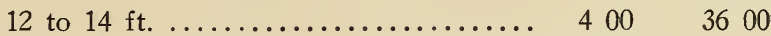

26000

Specimens 3 to 5 in. ........\$8 00 to 3500

pedunculata syn. robur

English Oak

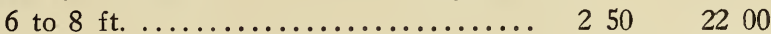

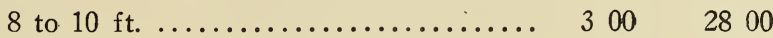

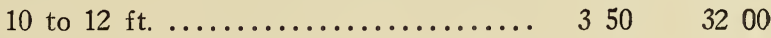

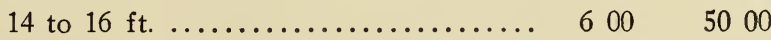

rubra

Red Oak

8 to $10 \mathrm{ft} . \ldots \ldots \ldots \ldots \ldots \ldots \ldots \ldots \ldots . \ldots 200 \quad 1800$

10 to $12 \mathrm{ft} . \ldots \ldots \ldots \ldots \ldots \ldots \ldots \ldots \ldots \ldots 250 \quad 2200$

20000

12 to $14 \mathrm{ft} . \ldots \ldots \ldots \ldots \ldots \ldots \ldots \ldots \ldots . \ldots \ldots, 300 \quad 2800 \quad 25000$

velutina

Specimens $21 / 2$ to 4 in........\$7 50 to 2500

3 large specimens, 5 to 6 in......... 5000

Black Oak

ROBINIA pseudacacia

..\$7 50 to 2500

Black Locust

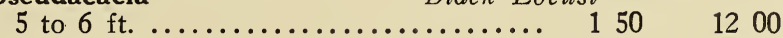

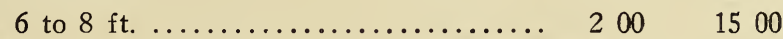

SALIX alba

White Willow

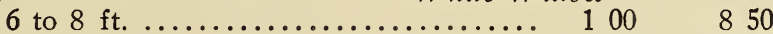

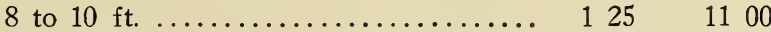

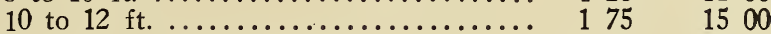

9000

12500

babylonica

15 to $18 \mathrm{ft}$., high branched

$300 \quad 2500$

6 to $8 \mathrm{ft}$.

Weeping Willow

8 to $10 \mathrm{ft}$

150

pentandra

Laurel-leaved Willow

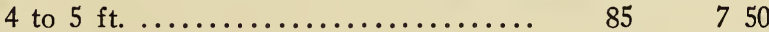

5000

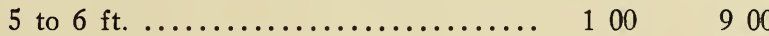

7000

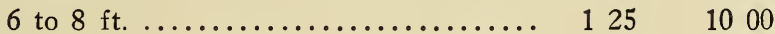

8000

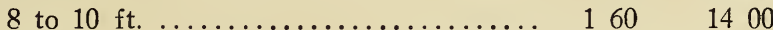

12000

vitellina aurea

Golden-barked Willow

6 to $8 \mathrm{ft}$......................... $125 \quad 1000 \quad 7000$

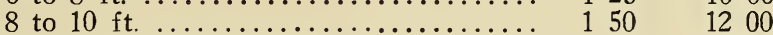

12 to $15 \mathrm{ft}$., high branched ............ $200 \quad 1600$

10000

SASSAFRAS officinale

Sassafras

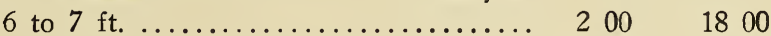

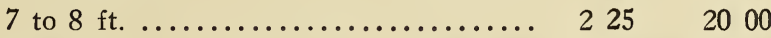

SORBUS aucuparia

European Mountain Ash

6 to $8 \mathrm{ft} \ldots \ldots \ldots \ldots \ldots \ldots \ldots \ldots \ldots \ldots \ldots$. $150 \quad 1200$

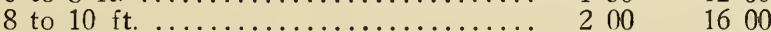

10 to $12 \mathrm{ft} . \ldots \ldots \ldots \ldots \ldots \ldots \ldots \ldots \ldots . \ldots . \ldots . \ldots 250 \quad 2200$

12000

20000

quercifolia

Oak-leaved Mountain Ash

8 to $10 \mathrm{ft} . \ldots \ldots \ldots \ldots \ldots \ldots \ldots \ldots . \ldots . \ldots . \ldots . \ldots$

12 to $14 \mathrm{ft} . \mathrm{XX} \ldots \ldots \ldots \ldots \ldots \ldots . \ldots . \ldots . \ldots 50$

SYRINGA japonica

Japanese Tree Lilac

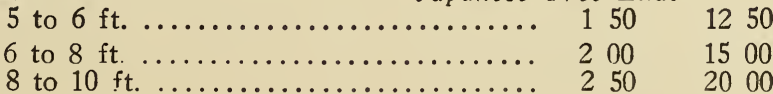

100 on

12000 
TAXODIUM distichum

Eald Cach

Per 10 Per 100

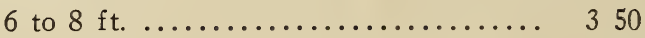

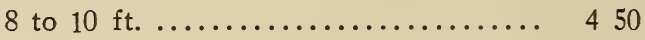

TILIA americana

American Linden

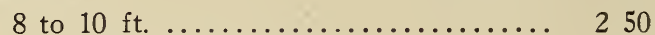

$2200 \quad 20000$

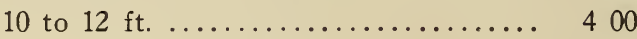

$3600 \quad 32000$

12 to $14 \mathrm{ft} .2$ to $2 \mathrm{r} / 2$ in............... $500 \quad 4500$

12 to $14 \mathrm{ft}$. specimens $2 \mathrm{r} / 2$ to $3 \mathrm{in} . \ldots .6600 \quad 5500$

14 to $15 \mathrm{ft}$. specimens 3 to 4 in., $\$ 1000$ to 2500

parvifolia

Small-leaved European Linden

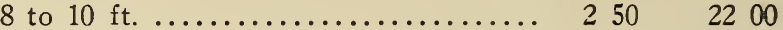

20000

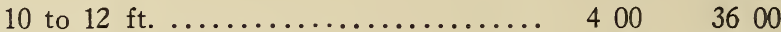

32000

12 to $14 \mathrm{ft} .2$ to $2 \frac{1}{2}$ in............. $500 \quad 4500$

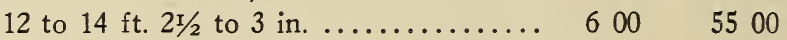

Specimens 3 to 4 in. caliper.... \$10 00 to 2500

platyphyllos

Large-leaved Linden

8 to $10 \mathrm{ft} . \ldots \ldots \ldots \ldots \ldots \ldots \ldots \ldots . \ldots . \ldots 250 \quad 2000$

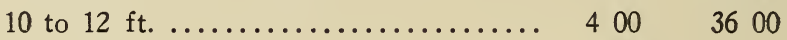

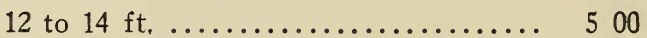

spectabilis

White or Silver Linden

8 to $10 \mathrm{ft} . \ldots \ldots \ldots \ldots \ldots \ldots \ldots . \ldots . \ldots . \ldots 250$

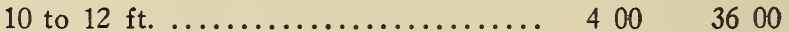

12 to $14 \mathrm{ft} ., 2$ to 3 in.............. $500 \quad 4500$

ULMUS americana American Elm

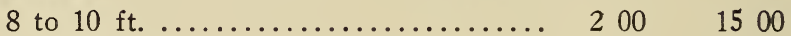

10 to $12 \mathrm{ft} . \ldots \ldots \ldots \ldots \ldots \ldots \ldots \ldots \ldots . .300 \quad 2500$

12 to $14 \mathrm{ft} .2 \mathrm{r} / 2$ to $3 \mathrm{in}$. caliper ....... $500 \quad 4200$

22000

huntingdoni

Huntingdon Elm

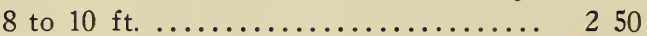

2200

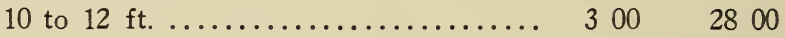

wheatleyii

Cornish Elm

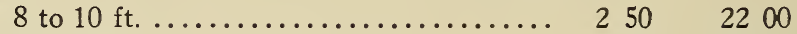

10 to $12 \mathrm{ft} . \ldots \ldots \ldots \ldots \ldots \ldots \ldots \ldots \ldots .300 \quad 3800$

dumont

Dumont's Elm

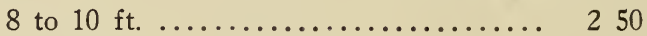

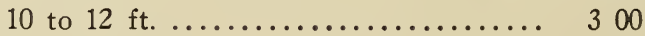

presthans Fastigiate Elm

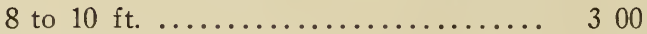

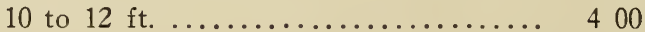

scabra

Scotch or Wych Elm

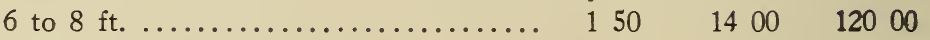

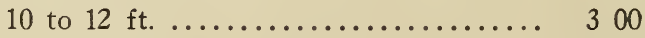

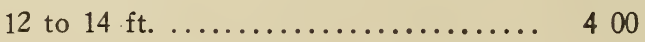

14 to $16 \mathrm{ft}$. specimens........\$8 00 to 1500

VIRGILIA (See Cladrastis)

See CONDITIONS OF SALE on page 2. 


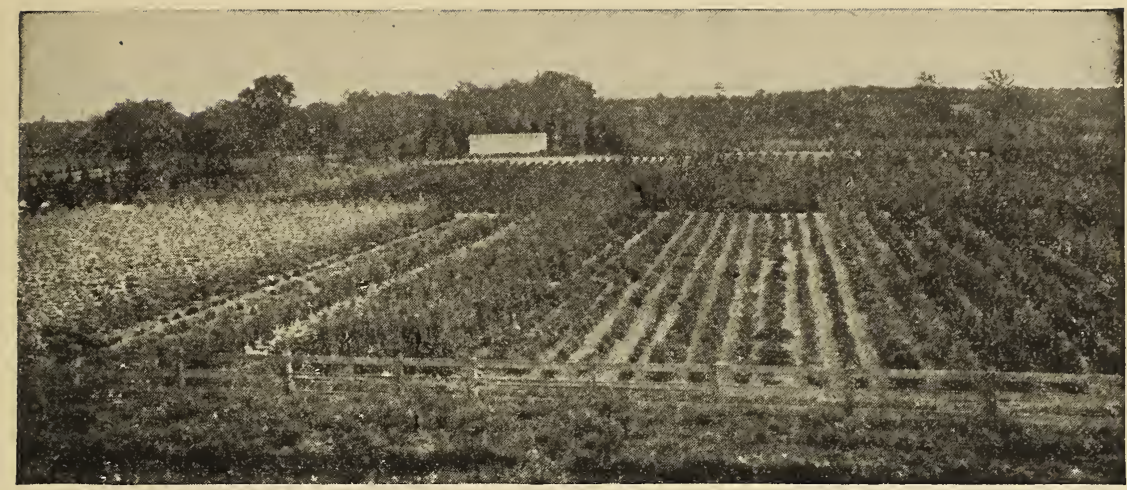

A Partial View of Our Evergreens in the Nursery

MEDAL OF HONOR AWARDED US AT THE PANAMA-PACIFIC EXPOSITION IN 1915 FOR EVERGREENS

\section{EVERGREEN TREES}

These Evergreens are all thrifty and heavily rooted, and have been several times transplanted. We have a number of large specimen Evergreens in variety not listed. They can be seen at the nursery when prices will be given. It will pay to see them if interested.

All Evergreens will be B \& B (balled and burlapped), without extra charge. In the case of small trees several will be lifted with a ball and wrapped together in one bundle; all larger trees will be burlapped separately.

Each Per 10 Per 100

ABIES balsamea

Balsam Fir

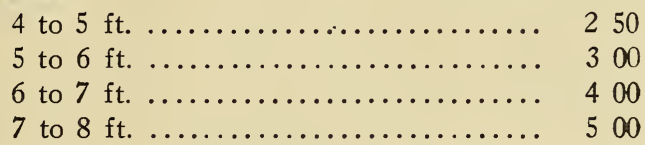

b. var. hudsonica Hudson Bay Fir

8 to 12 in. spread ............... 250

brachyphylla

Short-leaved Fir

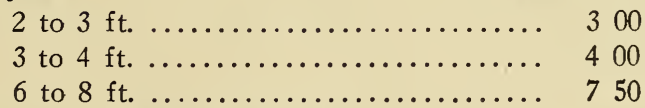

canadensis (See Tsuga Canadensis) Hemlock

concolor

White Fir

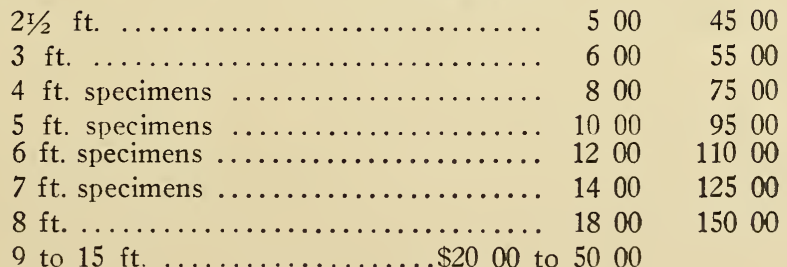


ABIES - continued

veitchii

Each

Per 10

Per 100

Japanese Fir
6 to $7 \mathrm{ft}$
600
5500
7 to $8 \mathrm{ft}$
700
6500
8 to $9 \mathrm{ft}$
800
7500

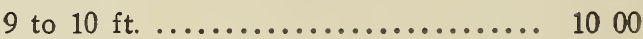

CHAMAECYPARIS (See Retinospora)

JUNIPERUS chinensis

Chinese Juniper

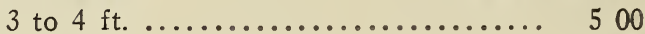

4 to $5 \mathrm{ft} . \ldots \ldots \ldots \ldots \ldots \ldots \ldots \ldots \ldots . \ldots \ldots$

5 to $6 \mathrm{ft} . \ldots \ldots \ldots \ldots \ldots \ldots \ldots \ldots . . . . .600$

c. var. alba variegata

Silver-tipped Juniper

2 to $3 \mathrm{ft} . \ldots \ldots \ldots \ldots \ldots \ldots \ldots \ldots \ldots . \ldots \ldots$

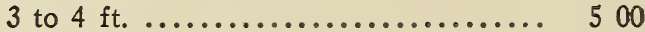

4 to $5 \mathrm{ft} . \ldots \ldots \ldots \ldots \ldots \ldots \ldots \ldots \ldots, 600 . \ldots \ldots$

5 to $6 \mathrm{ft} . \ldots \ldots \ldots \ldots \ldots \ldots \ldots \ldots . \ldots \ldots$

c. var. aurea

Golden Chinese Juniper

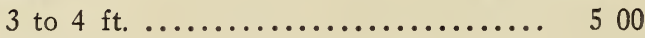

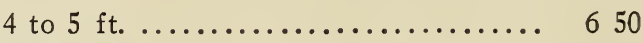

c. var. pfitzeriana

Pfitzer's Juniper

18 to 24 in. spread ................. 300

2750

24 to 30 in. spread ............... 450

4000

30 to 36 in. spread .............. $600 \quad 5500$

3 to $4 \mathrm{ft}$. spread XX ............... $900 \quad 8000$

communis depressa

Common Spreading Juniper

15 to 18 in. spread ................ $160 \quad 1400$

12000

18 to 24 in. spread ............... $200 \quad 1800$

2 to $2 \mathrm{r} / 2$ ft. spread ............... $250 \quad 2200$

$2 \mathrm{r} / 2$ to $3 \mathrm{ft}$. spread ................ 350

3 to $4 \mathrm{ft}$. spread ................ $5 \cdot 00$

com. var. hibernica

Irish Juniper

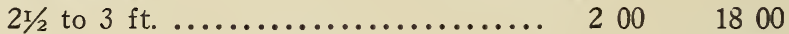

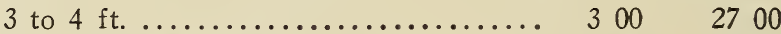

4 to $5 \mathrm{ft}$. specimens ............... $400 \quad 3500$

25000

30000

com. var. procumbens

2 to $3 \mathrm{ft}$

Flat Trailing Juniper

suecica Swedish Juniper

2 to $2 \mathrm{r} / 2$ ft. ....................... 160

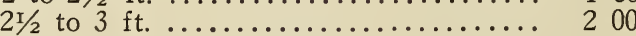

com. var. suecica

1800

excelsa var. stricta

Greek Juniper

10 to 12 in. ..................... 175

japonica

Japanese Juniper

18 to 24 in. ..................... 300

2 to $2 \mathrm{r} / 2 \mathrm{ft} . \ldots \ldots \ldots \ldots \ldots \ldots \ldots \ldots . . \ldots \ldots$

var. aurea

Golden Japanese Juniper

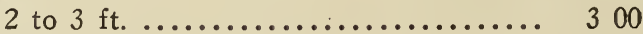

3 to $4 \mathrm{ft} . \ldots \ldots \ldots \ldots \ldots \ldots \ldots \ldots \ldots . . .60$ 
JUNIPERUS - continued

Each Per 10 Per 100

macrocarpa (neaboriensis)

Large-fruited Juniper

2 to $3 \mathrm{ft}$.

400

4 to $5 \mathrm{ft}$.

700

sabina

Savin Juniper

15 to 18 in.

$175 \quad 1500$

18 to 24 in...................... 250

2 to $2 \mathrm{I} / 2 \mathrm{ft}$. spread

300

$2 \mathrm{r} / 2$ to $3 \mathrm{ft}$. spread

450

4200

8. var. tamariscifolia

Tamarisk-leaved Savin

18 to 24 in.

400

virginalis var. globosa

Japanese Globe Juniper

12 to 15 in. spread ................. 360

15 to 18 in. ..................... 500

18 to 24 in. ...................... 650

virginiana

Red Cedar

3 to $4 \mathrm{ft}$

300

2800

26000

4 to $5 \mathrm{ft}$

400

3800

5 to $6 \mathrm{ft}$

600

5500

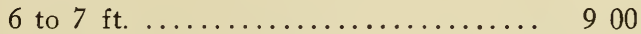

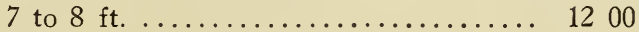

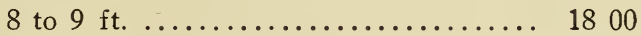

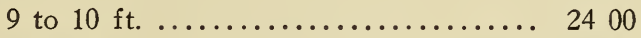

v. var. cannartii

Columnar Tufted Cedar

3 to $4 \mathrm{ft} . \ldots \ldots \ldots \ldots \ldots \ldots \ldots . \ldots . \ldots$

v. var. elegantissima

Lee's Golden Cedar

$2 \mathrm{r} / 2$ to $3 \mathrm{ft}$

450

v. var. glauca

Blue Cedar

$2 \mathrm{1} / 2$ to $3 \mathrm{ft} . \ldots \ldots \ldots \ldots \ldots \ldots \ldots \ldots \ldots \ldots \ldots \ldots \ldots \ldots \ldots \ldots \ldots$

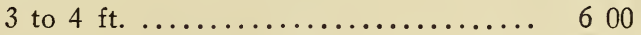

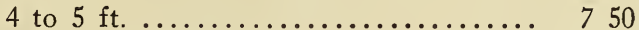

5 to $6 \mathrm{ft}$. specimens ............... 1000

6 to $7 \mathrm{ft}$. specimens ................ 1300

v. var. schotti

Tall Columnar Cedar

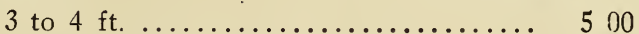

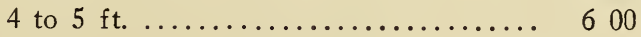

PICEA alba

White Spruce

2 to $3 \mathrm{ft}$

$200 \quad 1800$

3 to $4 \mathrm{ft}$.

$275 \quad 2500$

4 to $5 \mathrm{ft}$.

$400 \quad 3600$

5 to $6 \mathrm{ft}$.

500 
PICEA - continued

canadensis

Each Per 10 Per 100

Black Hill White Spruce

7 to $8 \mathrm{ft}$. specimens............... $900 \quad 8000$

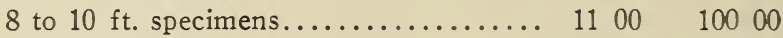

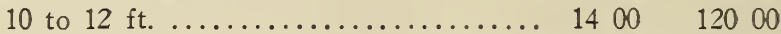

engelmanni

Engelman's Spruce

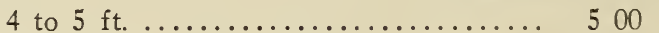

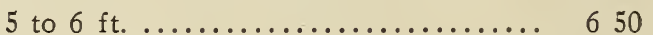

$4500 \quad 400$ on

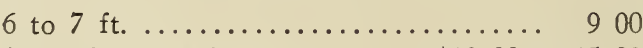

$6000 \quad 55000$

7 to $12 \mathrm{ft}$. specimens ........\$12 00 to 2500

excelsa

Norway Spruce

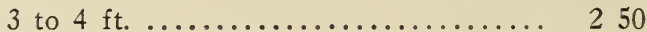

$2250 \quad 20000$

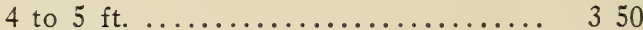

$3200 \quad 30000$

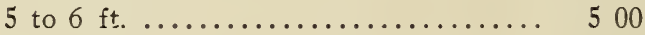

4500

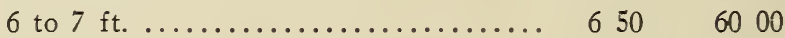

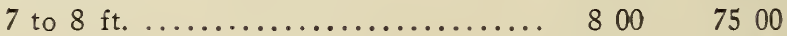

60000

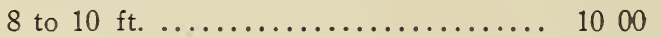

$9000 \quad 70000$

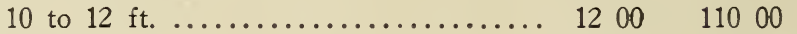

90000

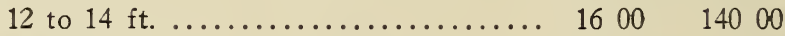

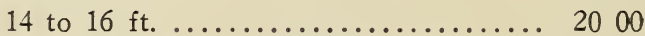

WE CALL SPECIAL ATTENTION TO OUR LARGE VARIETY OF DWARF SPRUCES.

ex. var. barryi

Barry's Dwarf Spruce

12 to 15 in. spread ..........\$5 00 to 1000

18 to 24 in. spread .......... 500 to 1000

ex. var. compacta

Drearf Spruce

3 to $4 \mathrm{ft}$. spread ...........\$15 00 to 2500

4 to $5 \mathrm{ft}$. spread ............ 1500 to 2500

ex. var. conica

Dwarf Spruce

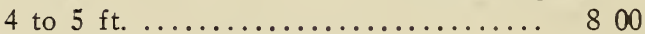

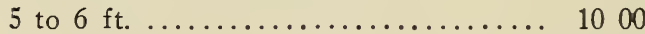

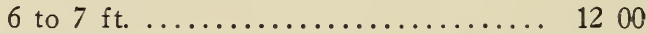

ex. var. dumosa

Drcarf Spruce

3 to $4 \mathrm{ft} . \ldots \ldots \ldots \ldots \ldots \ldots \ldots 2000$ to 2500

ex. var. gregoryana

Gregory's Spruce

2 to $3 \mathrm{ft}$............... $\$ 1500$ to 2500

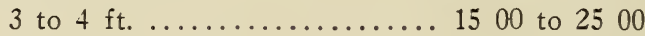

4 to $5 \mathrm{ft} . \ldots \ldots \ldots \ldots \ldots \ldots \ldots \ldots$ to 2500

ex. var. inversa

Heeping Norway Spruce

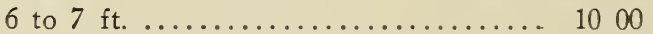

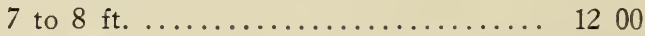

ex. var. maxwelli

Marwell's Spruce

12 to 15 in. spread ......... $\$ 1000$ to 2500

18 to 24 in. spread ......... 1000 to 2500

$2 \mathrm{ft}$ spread ............... 1000 to 2500

Large specimens ............... 5000 
PICEA - continued

ex. var. procumbens

Each

Per 10 Per 100

$2 \mathrm{r} / 2$ to $3 \mathrm{ft}$. spread .......... $\$ 1500$ to 2500

3 to $3 \mathrm{r} / 2$ ft. spread .......... 1500 to 2500

ex. var. pumila

Dwarf Spruce

18 to 24 in. spread...........\$10 00 to 3500

2 to $2 \mathrm{r} / 2 \mathrm{ft}$. spread........... 1000 to 3500

$2 \mathrm{r} / 2$ to $3 \mathrm{ft}$. spread........... 1000 to 3500

3 to $3 \mathrm{r} / 2 \mathrm{ft}$. spread........... 1000 to 3500

ex. var. pygmea

Dwarf Spruce

$15 \times 18$ in. spread...........\$5 00 to 1000

18 to 24 in. spread........... 500 to 1000

nigra

Black Spruce

3 to $4 \mathrm{ft}$.

250

2250

omorika

Servian Spruce

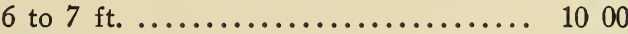

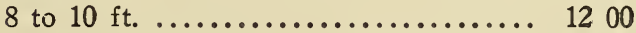

orientalis

Eastern Spruce

18 to 24 in.

$300 \quad 2500$

24 to 30 in

$400 \quad 3500$

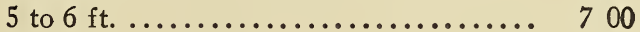

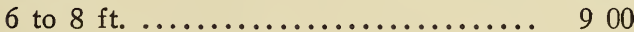

polita

Tiger Tail Spruce

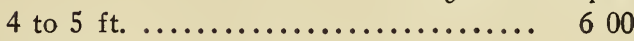

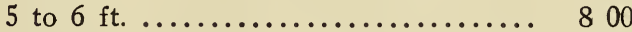

6 to $7 \mathrm{ft} . \ldots \ldots \ldots \ldots \ldots \ldots \ldots \ldots \ldots, 1000$

pungens

Colorado Green Spruce

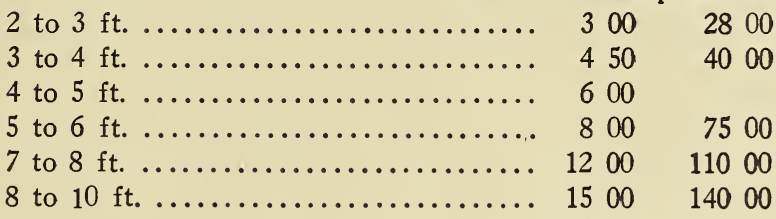

pungens var. glauca Colorado Blue Spruce

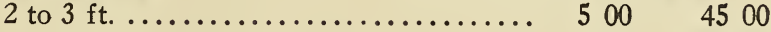

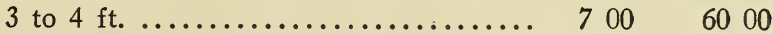

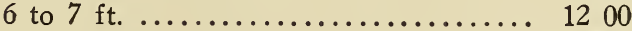

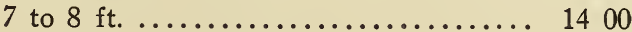

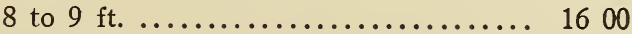

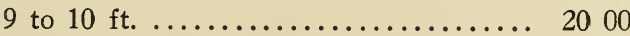

10 to $15 \mathrm{ft} . \ldots \ldots \ldots \ldots \ldots \ldots \ldots \ldots+\ldots 2500$ to 5000

We have a fine stock of Colo. Blue Spruce in large specimens; they have been several times transplanted so that they will transplant easily and thrive. Come and see them. 
PICEA - continued

2 to $3 \mathrm{ft}$

3 to $4 \mathrm{ft}$.

6 to $7 \mathrm{ft}$.

7 to $8 \mathrm{ft}$.

8 to $9 \mathrm{ft}$.

9 to $10 \mathrm{ft}$.

10 to $12 \mathrm{ft}$. p. var. kosteriana

Each Per 10

Per 100

Koster's Blue Spruce

$600 \quad 50.00$

$800 \quad 7000$

$1500 \quad 14000$

$\begin{array}{llll}18 & 00 & 16000\end{array}$

$2200 \quad 20000$

$2500 \quad 24000$

.$\$ 3000$ to 5000

Special prices on above in large lots.

PINUS austriaca

2 to $3 \mathrm{ft}$.

Austrian Pine

3 to $4 \mathrm{ft}$.

275

2500

22500

4 to $5 \mathrm{ft}$.

400

500

3800

4800

5 to $6 \mathrm{ft}$.

750

8 to $9 \mathrm{ft}$.

1200

9 to $10 \mathrm{ft}$.

1500

cembra

2 to $3 \mathrm{ft}$.

Swiss Stone Pine

3 to $4 \mathrm{ft}$.

400

4 to $5 \mathrm{ft}$.

500

4500

5 to $6 \mathrm{ft}$.

700

6500

9000

36000

42500

65000

densiflora

Japanese Red Pine

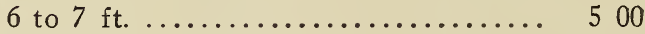

7 to $8 \mathrm{ft}$

600

var. globosa

Japanese Table Pine

18 to 24 in. diameter .............. 500

montana

Mountain Pine

2 to $2 \mathrm{r} / 2 \mathrm{ft}$. high ................. 350

$2 \mathrm{r} / 2$ to $3 \mathrm{ft}$. high $\ldots \ldots \ldots \ldots \ldots \ldots \ldots \ldots$. 450

3200

3 to $4 \mathrm{ft}$. high

$600 \quad 5500$

4 to $5 \mathrm{ft}$. high

5 to $6 \mathrm{ft}$. high

900

8500

var. mughus

Dwarf Mountain Pine

12 to 15 in. spread ................. $160 \quad 1400$

12000

15 to 18 in. spread

$225 \quad 2000$

16000

18 to 24 in. spread

$300 \quad 2800$

2 to $2 \mathrm{r} / 2 \mathrm{ft}$. spread

$400 \quad 3800$

$2 \mathrm{r} / 2$ to $3 \mathrm{ft}$. spread

$500 \quad 4800$

3 to $3 \mathrm{r} / 2 \mathrm{ft}$. spread

750

7000

$3 \mathrm{r} / 2$ to $4 \mathrm{ft}$. spread

$1000 \quad 9000$

4 to $5 \mathrm{ft}$.

$1250 \quad 12000$

5 to $6 \mathrm{ft}$.

1500

resinosa

Red Pine

3 to $4 \mathrm{ft}$.

250

2000

4 to $5 \mathrm{ft}$.

300

2500

5 to $6 \mathrm{ft}$.

400

3600

17500

20000

30000 
PINUS - continued

strobus

2 to $3 \mathrm{ft}$

3 to $4 \mathrm{ft}$.

4 to $5 \mathrm{ft}$.

5 to $6 \mathrm{ft}$

6 to $7 \mathrm{ft}$

7 to $8 \mathrm{ft}$.

sylvestris

2 to $3 \mathrm{ft}$

3 to $4 \mathrm{ft}$.

8 to $10 \mathrm{ft}$. specimens

10 to $12 \mathrm{ft}$. specimens

wateriana

4 to $5 \mathrm{ft}$.

Dwarf Pine

2000

\section{PSEUDOTSLGA texifolia}

3 to $4 \mathrm{ft}$.

Douglas Spruce

4 to $5 \mathrm{ft}$.

400

5 to $6 \mathrm{ft}$.

500

700

6 to $7 \mathrm{ft}$.

900

7 to $8 \mathrm{ft}$. specimens

1000

8 to $10 \mathrm{ft}$. specimens

1200

10 to $12 \mathrm{ft}$. specimens

1500

12 to $14 \mathrm{ft}$. specimens
2000
35000

45000

60000

\section{RETINISPORA filifera}

Thread-branched Cypress

2 to $3 \mathrm{ft}$. 400 3500

3 to $4 \mathrm{ft}$.

500

4 to $5 \mathrm{ft}$.

650

5 to $6 \mathrm{ft}$.

800

8 to $10 \mathrm{ft}$

$\$ 1200$ to 2000

flifera var. aurea.

18 in. spread

Golden Thread-branched Cypress

$2 \mathrm{ft}$. spread ................... 600

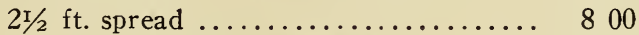

3 to $4 \mathrm{ft}$. upright specimens ......... 1500

4 to $5 \mathrm{ft}$. upright specimens ......... 2000

obtusa

Tree Cypress of Japan

2 to $3 \mathrm{ft}$. 500 4500

obtusa var. gracilis

Dwarf Cypress

2 to $2 \mathrm{r} / 2 \mathrm{ft} . \ldots \ldots \ldots \ldots \ldots \ldots \ldots \ldots . \ldots \ldots+450$

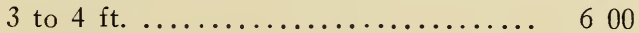

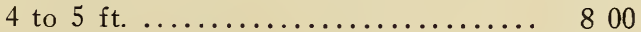

pisifera

Pea-fruited Cypress

3 to $4 \mathrm{ft}$.

450

4000

6 , to $8 \mathrm{ft}$.

1000

8 to $10 \mathrm{ft}$.

$1400 \quad 12000$

20000

30000 


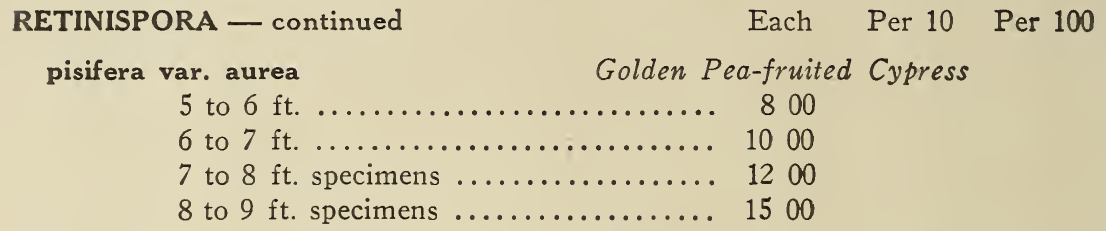

plumosa

Plumed Cypress

2 to $2 \mathrm{r} / 2 \mathrm{ft}$. sheared specimens ........ 300

2750

$2 \mathrm{r} / 2$ to $3 \mathrm{ft}$. sheared specimens ......... $400 \quad 3750$

3 to $4 \mathrm{ft}$. sheared specimens .......... $500 \quad 4750$

4 to $5 \mathrm{ft}$. sheared specimens .......... $700 \quad 6500$

5 to $6 \mathrm{ft}$. sheared specimens ......... 800

plumosa aurea Golden Plumed Cypress

2 to $2 \mathrm{r} / 2 \mathrm{ft}$. sheared specimens ......... $300 \quad 2800$

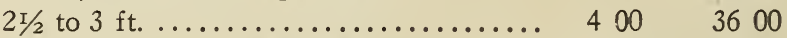

3 to $4 \mathrm{ft}$. sheared specimens .......... $500 \quad 4800$

4 to $5 \mathrm{ft}$. sheared specimens .......... 700

5 to $6 \mathrm{ft}$. sheared specimens ......... 800 .

6 to $7 \mathrm{ft}$ specimens ................ $900 \quad 8000$

7 to $8 \mathrm{ft}$. sheared specimens .......... $1000 \quad 9000$

plu. var. lutescens (Globe form)

10 to 12 in. .................... 200

12 to 15 in. .................... 250

plu. var. sulphurea Sulphur-plumed Dwarf Cypress

18 to 24 in. ...................... $300 \quad 2800$

2 to $2 \mathrm{t} / 2 \mathrm{ft} . \ldots \ldots \ldots \ldots \ldots \ldots \ldots \ldots \ldots \ldots, 400 \quad 3600$

squarrosa (veitchii) Gray Cypress

2 to $2 I^{\prime} / 2$ ft. sheared specimens ......... $350 \quad 3200$

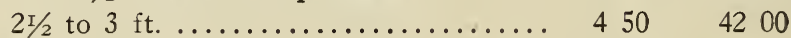

5 to $6 \mathrm{ft} . \ldots \ldots \ldots \ldots \ldots \ldots \ldots . \ldots 1000$

6 to $8 \mathrm{ft}$. sheared specimens.... $\$ 1200$ to 1500

SCIADOPITYS verticillata Umbrella Pine

$2 \mathrm{~T} / 2$ to $3 \mathrm{ft} . \ldots \ldots \ldots \ldots \ldots \ldots \ldots \ldots . \ldots \ldots$

3 to $3 \mathrm{r} / 2 \mathrm{ft} . \ldots \ldots \ldots \ldots \ldots \ldots \ldots \ldots \ldots \ldots, 800$

$3 \mathrm{r} / 2$ to $4 \mathrm{ft}$. specimens ............. 1000

4 to $5 \mathrm{ft}$. specimens ................ 1500

5 to $6 \mathrm{ft}$. specimens ............... 2000

TAXUS baccata var. elegantissima Elegant English Yerw

10 to $12 \mathrm{ft}$. spread ................. $175 \quad 1500$

12 to 15 in. spread ................. $225 \quad 2000$

b. var. washingtoni Washington's English Yere

18 in. ........................ $250 \quad 2200$

canadensis

American Yew

15 to 18 in. spread ................. $175 \quad 1500 \quad 13000$

18 to 24 in. ...................... 250

24 to 30 in. ................... 300 
TAXUS - continued cuspidata

Japanese Yew

Each Per 10 Per 100

12 to 15 in. upright form ........... $175 \quad 1500$

15 to 18 in. .................... $250 \quad 2200$

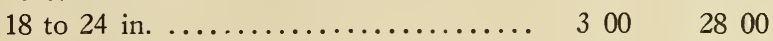

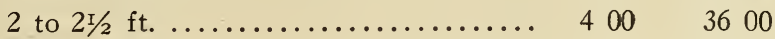

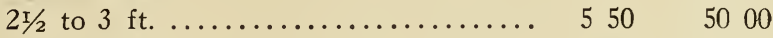

3 to $31 / 2$ ft........................ $700 \quad 6500$

c. var. nana (brevifolia) Short-leaved Japanese Yerw

10 to 12 in. upright compact form .... $300 \quad 2700$

12 to 15 in. ........................ $360 \quad 3200$

12 to 15 in. spreading form ......... $250 \quad 2250$

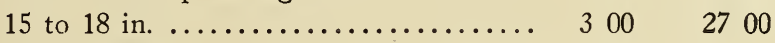

18 to 24 in. ..................... 500

$2 \mathrm{r} / 2$ to $3 \mathrm{r} / 2 \mathrm{ft}$. specimens... from $\$ 1500$ to 3000

Absolutely hardy-one of the best yews.

repandens

Spreading Yere

15 to 18 in. spread ............... $270 \quad 2500$

18 to 24 in. spread .............. $400 \quad 3600$

24 to 30 in. spread ............. $500 \quad 4500$

THUYA occidentalis

American Arborvitae

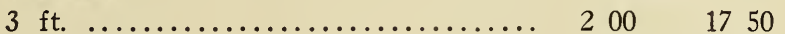

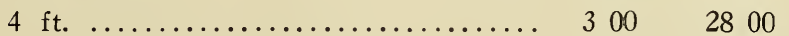

15000

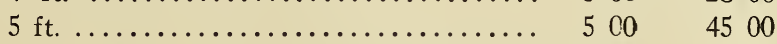

25000

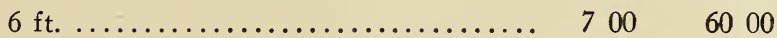

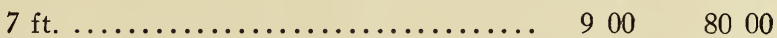

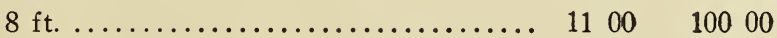

$9 \mathrm{ft}$. specimens ....................... $1200 \quad 11000$

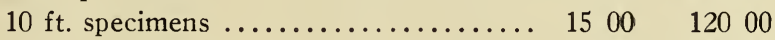

$12 \mathrm{ft}$. specimens .................. $2000 \quad 15000$

$13 \mathrm{ft}$. specimens ................. $2500 \quad 20000$

$14 \mathrm{ft}$. specimens ................ $3000 \quad 25000$

$16 \mathrm{ft} . \ldots \ldots \ldots \ldots \ldots \ldots \ldots \ldots . \ldots . \ldots . \ldots 3500 \quad 30000$

oc. var. alba spica

Spire-like Arborvitae

$8 \mathrm{ft}$. specimens ................. 800

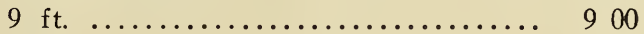

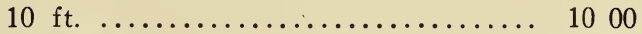

oc. var. comvacta Parson's Dwarf Arborvitae

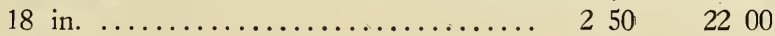

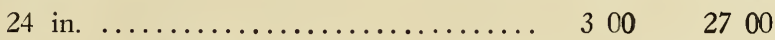

oc. var. douglasii pyramidalis (spiralis) Douglas Pyramidal Arborvitae

2 to $2 \mathrm{I} / 2 \mathrm{ft}$.

250

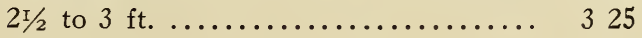

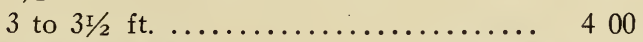

oc. var. ellwangeriana Ellwanger's Arborvitae

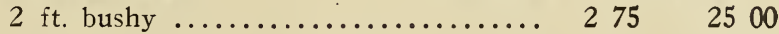

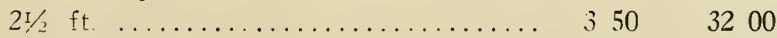

$3 \mathrm{ft}$. bushy ................. $450 \quad 4200$ 


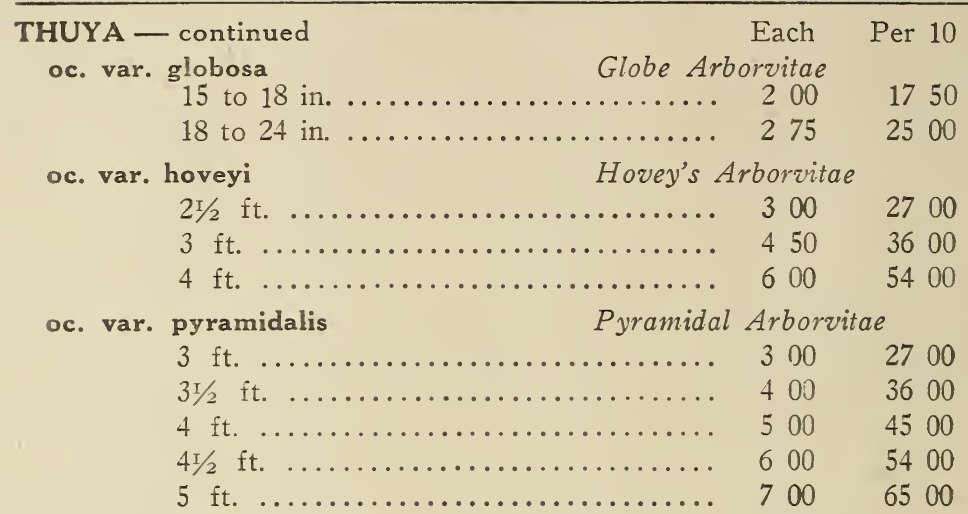

oc. var. siberica

18 to 24 in.

2 to $2 \mathrm{I} / 2 \mathrm{ft}$

$2 \mathrm{~T} / 2$ to $3 \mathrm{ft}$

4 to $5 \mathrm{ft}$.

Siberian Arborvitae

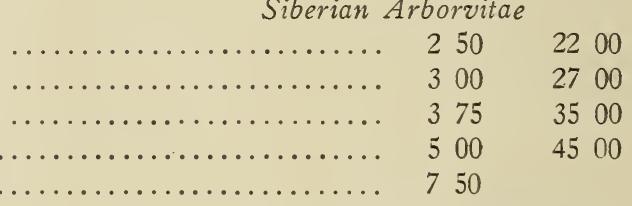

umbraculifera

15 to 18 in. diameter

Dwarf Globe Arborvitae

18 to 24 in.

oc. var. vervaeneana

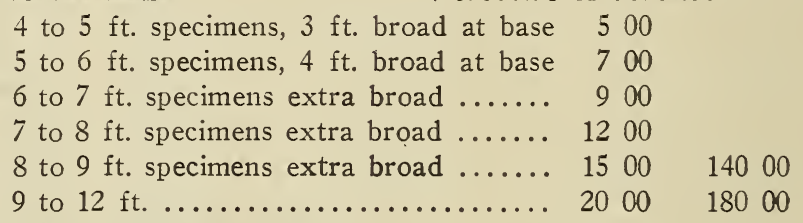

Our stock is all fine, bushy plants.

\section{TSUGA canadensis}

24 to $30 \mathrm{in}$.

30 to 36 in.

3 to $3 \mathrm{t} / 2 \mathrm{ft}$

$3 \mathrm{r} / 2$ to $4 \mathrm{ft}$.

4 to $5 \mathrm{ft}$.

5 to $6 \mathrm{ft}$.

5 to $6 \mathrm{ft}$. extra broad

6 to $7 \mathrm{ft}$.

6 to $7 \mathrm{ft}$ extra broad

7 to $8 \mathrm{ft}$.

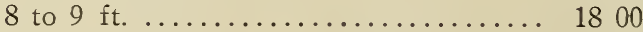

8 to $9 \mathrm{ft}$. extra broad .............. 2000

9 to $10 \mathrm{ft} . \ldots \ldots \ldots \ldots \ldots \ldots . . . . . .2000$

9 to $12 \mathrm{ft}$. extra broad .................. 2500

10 to $12 \mathrm{ft} . \ldots \ldots \ldots \ldots \ldots \ldots \ldots . \ldots . \ldots 2500$
Per 100

16500

24000

25000

34000

50000 


\section{EVERGREEN SHRUBS}

ANDROMEDA axillaris (See Leucothoe)

A. floribunda (See Pieris)

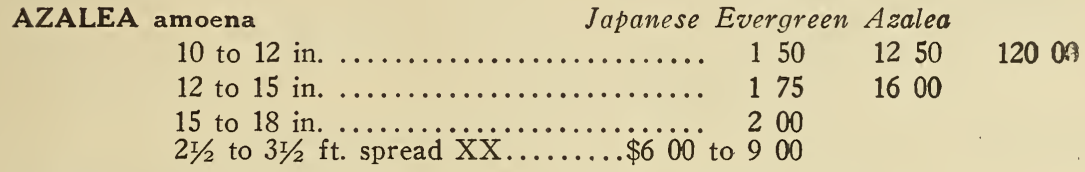

japonica var. hinode-giri Pink Evergreen Azalea

12 to 15 in. .................... $175 \quad 1500$

15 to 18 in. .................... 225

BERBERIS aquilifolium (See Mahonia acquifolium)

\section{BUXUS}

sempervirens varieties

\begin{tabular}{|c|c|c|}
\hline Bush Box & & \\
\hline$\ldots \ldots \ldots \ldots \ldots \ldots \ldots \ldots$ & 100 & 900 \\
\hline 18 to 24 in. ......... & 500 & 4600 \\
\hline 24 to 30 in. .......... & 700 & 6500 \\
\hline
\end{tabular}

Dome Box

$3 \mathrm{ft}$. 1000

Globe Box

18 to 24 in

Pyramidal Box

2 to $21 / 2$ ft. ................... 500

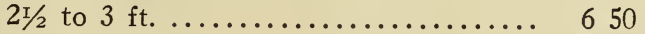

3 to $3 \mathrm{r} / 2 \mathrm{ft} . \ldots \ldots \ldots \ldots \ldots \ldots \ldots \ldots \ldots \ldots \ldots \ldots$

\section{CALLUNA}

Heather

compacta (dwarf)

erecta alba

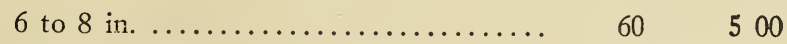

erecta rubra

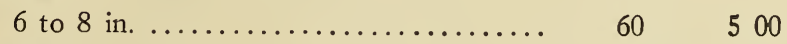

vulgaris alba

\begin{tabular}{|c|c|}
\hline & 60 \\
\hline 3 to 10 in $\ldots \ldots \ldots \ldots \ldots \ldots \ldots \ldots \ldots \ldots$ & 75 \\
\hline
\end{tabular}

var. alportii

6 to 8 in.

$60 \quad 500 \quad 4000$

var. aurea

6 to 8 in. 
CALLUNA - continued

Each Per 10 Per 100

var. carnea

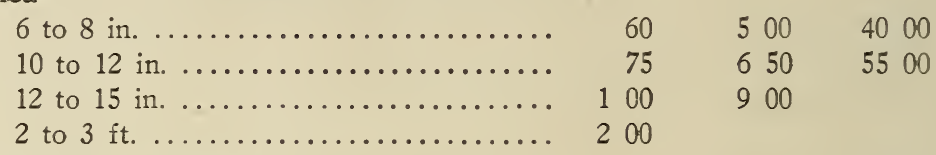

CHAMAEDAPHNE calyculata

Leather Leaf

18 to 24 in. ................... 150

A desirable dwarf spreading border plant.

DAPHNE cneorum Garland Flower

6 to 8 in. spread .................. 75

8 to 10 in. spread .................. 100

$600 \quad 4500$

10 to 12 in. spread ................ $125 \quad 1000 \quad 8000$

12 to 15 in. spread ................ $150 \quad 1400 \quad 12000$

EUONYMUS radicans Evergreen Bittersweet

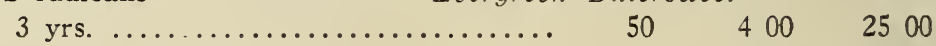

4 yrs. ........................... $65 \quad 550 \quad 3600$

var. minima (kewensis) Small-leaved Evergreen Bittersweet

Small dark-green foliage with lighter veins. Fine for carpeting the ground or as a rock-plant ............. $60 \quad 480 \quad 3300$

var. argentea marginata Variegated Evergreen Bittersweet

4 yrs. ........................ $65 \quad 500 \quad 3600$

var. carrierei Carrier's Evergreen Bittersweet

3 yrs. ....................... $50 \quad 400 \quad 3000$

4 yrs. ................................ $60 \quad 500 \quad 4000$

var. vegeta Broad-leaved Evergreen Bittersweet

3 yrs. $\ldots \ldots \ldots \ldots \ldots \ldots \ldots \ldots \ldots \ldots \ldots$
4 yrs. $\ldots \ldots \ldots \ldots$

ILEX glabra Inkberry

15 to 18 in. clumps ............. $200 \quad 1600$

18 to 24 in. clumps .............. $250 \quad 2200$

KALMIA angustifolia Sheep Laurel

12 to 15 in..................... $150 \quad 1200$

latifolia Mountain Laurel

18 to 24 in. .................... $250 \quad 2200 \quad 20000$

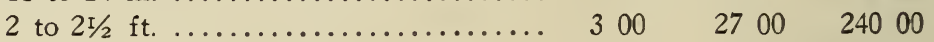

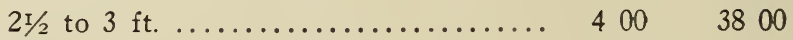

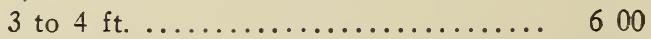

LEUCOTHOE catesbaei Drooping Andromeda

15 to 18 in. bushy .................. $150 \quad 1400 \quad 12000$

18 to 24 in. bushy ................ $180 \quad 1600 \quad 14000$

MAHONIA aquifolium Ashberry

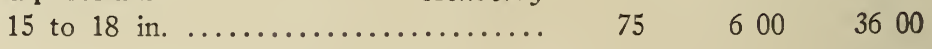




\section{Each Per 10 Per 100}

PACHYSANDRA terminalis Japanese Spurge

from $2 x / 2$ in. pots ...................... $25 \quad 200 \quad 1600$

from 3 in. pots extra heavy, 4 yrs. ... $\quad 30 \quad 250 \quad 1800$

\section{PIERIS floribunda (andromeda) Lily-of-the-valley Shrub}

18 in. spread .................... 400

2 ft. spread ................... 600

$2 \mathrm{r} / 2$ ft. spread $\ldots \ldots \ldots \ldots \ldots \ldots \ldots \ldots \ldots, 800$

\section{VINCA minor Myrtle}

$\$ 10000$ per M., pot grown .......... $25 \quad 220 \quad 1500$

See CONDITIONS OF SALE on page 2. 


\section{RHODODENDRONS}

Rhododendrons are one of our specialties. Our stock comprises many of the Hybrid varieties, all of which have been tested as to their merits for hardiness and beauty of flower; also the best of the Dwarf Alpine varieties.

The native Catawbiense and Maximum types we offer are all nursery grown, healthy and vigorous. We can, through our collector, furnish these types in collected plants of any quantity desired. Write giving sizes and quantities wanted, and we will make special quotations.

The prices of the various sizes of hardy Hybrid Rhododendrons except Boule de Neige are as follows:

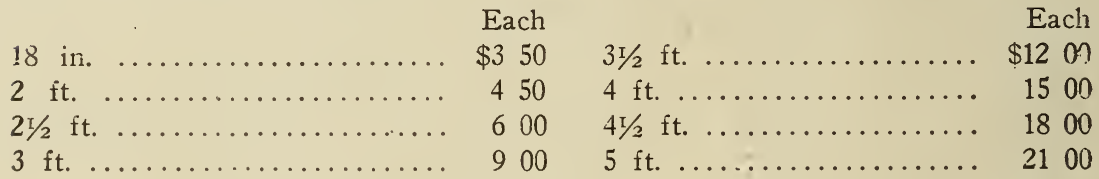

\section{RHODODENDRONS - HARDY HYBRID VARIETIES}

If we have not in stock the size of a variety ordered, we shall select the same size of another variety which most closely resembles it in color - UN. LESS OTHERWISE ADVISED.

We can furnish the following varieties in the various sizes, viz.:

Abraham Lincoln (Fine red) 18 in. $\quad 2 \mathrm{r} / 2 \mathrm{ft}$.

$2 \mathrm{ft}$.

Album Elegans (Large white) $2 \mathrm{r} / 2 \mathrm{ft}$. $\quad 4 \mathrm{ft}$. $3 \mathrm{ft}$. $3 \mathrm{r} / 2 \mathrm{ft}$.

$4 \mathrm{I} / 2 \mathrm{ft}$.

$5 \mathrm{ft}$.

Album Grandiflorum (Blu-h white)

$\begin{array}{ll}2 \mathrm{ft} . & 3 \mathrm{I} / 2 \mathrm{ft} . \\ 2 \mathrm{I} / 2 \mathrm{ft} . & 4 \mathrm{ft} . \\ 3 \mathrm{ft} . & 4 \mathrm{I} / 2 \mathrm{ft} .\end{array}$

Album Novum (White) $4 \mathrm{ft}$. $\quad 4 \mathrm{r} / 2 \mathrm{ft}$.

Alexander Dancer (Crimson) $2 \mathrm{ft}$. $2 \mathrm{r} / 2 \mathrm{ft}$.

Atrosanguineum (Scarlet) 18 in. $2 \mathrm{ft}$.

$2 \mathrm{r} / 2 \mathrm{ft}$.

Boule de Neige (Dwarf White)

$18 \times 18$ in. .... $\$ 400$

$24 \times 24$ in...... 5 no

$30 \times 30$ in. ..... 750

Candidissimum (White)

18 in.

$2 \mathrm{ft}$.

$2 \mathrm{r} / 2 \mathrm{ft}$.
$3 \mathrm{ft}$.

$3 \mathrm{r} / 2 \mathrm{ft}$.

$4 \mathrm{ft}$.
Caractacus (Rich crimson)

$\begin{array}{ll}18 \mathrm{in} . & 3 \mathrm{ft} . \\ 2 \mathrm{ft} . & 3 \mathrm{r} / 2 \mathrm{ft} . \\ 2 \mathrm{I} / 2 \mathrm{ft} . & 4 \mathrm{ft} .\end{array}$

Catawbiense Grand. Alba (White)

$\begin{array}{ll}18 \mathrm{in} . & 3 \mathrm{ft} . \\ 2 \mathrm{ft} . & 3 \mathrm{r} / 2 \mathrm{ft} . \\ 2 \mathrm{I} / 2 \mathrm{ft} . & 4 \mathrm{r} / 2 \mathrm{ft} .\end{array}$

Catherine von Tol (Rose) $4 \mathrm{r} / 2 \mathrm{ft}$.

Charles Bagley (Red)

$2 \mathrm{ft}$. $3 \mathrm{ft}$.

$2 \mathrm{r} / 2 \mathrm{ft}$.

Charles Dickens (Rich crimson) 18 in. $\quad 2 \frac{1}{2} \mathrm{ft}$. $2 \mathrm{ft}$.

C. S. Sargent (Bright scarlet) 18 in. $2 \frac{1}{2} \mathrm{ft}$. $2 \mathrm{ft}$.

$3 \mathrm{ft}$.

Delicatissimum (Blush white)

$2 \mathrm{ft}$. $3 \mathrm{t} / 2 \mathrm{ft}$.

$2 \mathrm{r} / 2 \mathrm{ft} . \quad 4 \mathrm{ft}$.

$3 \mathrm{ft}$.

Edward S. Rand (Rich crimson)

$2 \mathrm{ft}$. $3 \mathrm{ft}$.

$2 \mathrm{r} / 2 \mathrm{ft}$. 
RHODODENDRONS - Hardy Hybrids - continued

Everestianum (Rosy lilac)

18 in. $\quad 2 \frac{1}{2} \mathrm{ft}$.

$2 \mathrm{ft}$.

F. D. Godman (Crimson)

$2 \mathrm{ft}$.

$2 \mathrm{r} / 2 \mathrm{ft}$.

General Grant (Red)

$2 \mathrm{ft}$.

$2 \mathrm{r} / 2 \mathrm{ft}$.

$3 \mathrm{ft}$.

$3 \mathrm{r} / 2 \mathrm{ft}$.

General McIntosh (Large, red) $2 \mathrm{ft}$. $2 \mathrm{r} / 2 \mathrm{ft}$.

Giganteum (Bright rose) $2 \mathrm{ft}$.

Hanna Felix (Light red) $3 \mathrm{r} / 2 \mathrm{ft}$. $\quad 4 \mathrm{ft}$.

H. H. Hunnewell (Dark crimson) 18 in. $2 \mathrm{ft}$.

H. W. Sargent (Crimson)

$2 \mathrm{ft}$. $2 \mathrm{I} / 2 \mathrm{ft}$.

Ignatius Sargent (Pink) 18 in.

$2 \mathrm{r} / 2 \mathrm{ft}$.

$3 \mathrm{ft}$

Kettledrum (Crimson) $3 \mathrm{ft}$. $2 \mathrm{r} / 2 \mathrm{ft}$. $\quad 3 \mathrm{r} / 2 \mathrm{ft}$.

Lady Armstrong (Pale rose) 18 in. $3 \mathrm{ft}$. $2 \mathrm{ft}$. $2 \mathrm{r} / 2 \mathrm{ft}$.

$3 \mathrm{r} / 2 \mathrm{ft}$.

Lady Clermont (Dark red) $2 \mathrm{r} / 2 \mathrm{ft}$. $\quad 3 \mathrm{I} / 2 \mathrm{ft}$. $3 \mathrm{ft}$.

Lady Grey Egerton (Blush) $2 \mathrm{ft}$. $2 \mathrm{I} / 2 \mathrm{ft}:$

$3 \mathrm{ft}$. Dark Purple $2 \mathrm{ft}$. $2 \mathrm{r} / 2 \mathrm{ft}$.
Mme. Carvalho (White) 18 in. $3 \mathrm{ft}$. $2 \mathrm{ft} . \quad 3 \mathrm{t} / 2 \mathrm{ft}$.

$2 \mathrm{t} / 2 \mathrm{ft}$.

Mrs. Mendel (Pink, striated whito) $2 \mathrm{I} / 2 \mathrm{ft}$. $\quad 3 \mathrm{I} / 2 \mathrm{ft}$. $3 \mathrm{ft}$.

Mrs. Milner (Rich crimson) 18 in. $2 \mathrm{ft}$.

Mrs. R. S. Rand (Red) $2 \mathrm{ft}$. $2 \mathrm{I} / 2 \mathrm{ft}$.

Old Port (Dark red) $2 \mathrm{ft} . \mathrm{ft} \quad 3 \mathrm{ft}$.

Parson's Gloriosum (Large blush) $2 \mathrm{ft}$. $2 \mathrm{r} / 2 \mathrm{ft}$. $3 \mathrm{ft}$.

$3 \mathrm{I} / 2 \mathrm{ft}$. $4 \mathrm{ft}$. $4 \mathrm{I} / 2 \mathrm{ft}$.

Parson's Grandiflorum (Red) $2 \mathrm{ft}$. $\quad 4 \mathrm{ft}$. $2 \mathrm{I} / 2 \mathrm{ft}$. $\quad 4 \mathrm{I} / 2 \mathrm{ft}$.

President Lincoln (Rose) $\begin{array}{ll}2 \mathrm{ft} . & 3 \mathrm{ft} . \\ 2 \mathrm{r} / 2 \mathrm{ft} . & 4 \mathrm{I} / 2 \mathrm{ft} . \\ 2 \mathrm{ft} . & \\ 2 \mathrm{r} / 2 \mathrm{ft} . & 4 \mathrm{ft} . \\ 3 \mathrm{ft} . & 4 \mathrm{ft} / 2 \mathrm{ft} . \\ 3 \mathrm{I} / 2 \mathrm{ft} . & 5 \mathrm{ft} .\end{array}$

Roseum Superbum (Rose) $\begin{array}{ll}2 \mathrm{I} / 2 \mathrm{ft} . & 4 \mathrm{ft} . \\ 3 \mathrm{ft} . & 4 \mathrm{I} / 2 \mathrm{ft} . \\ 3 \mathrm{I} / 2 \mathrm{ft} . & \end{array}$

Sefton (Maroon crimson) $2 \mathrm{ft}$. $2 \mathrm{r} / 2 \mathrm{ft}$.

Sir Henry Ingersoll (Purplish red) $2 \mathrm{ft}$. $2 \mathrm{r} / 2 \mathrm{ft}$.

\section{RHODODENDRON CATAWBIENSE GRANDIFLORUM}

As hardy as the native Catawbience.

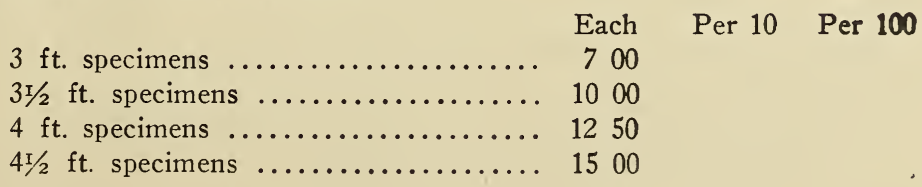


RHODODENDRON ALPINE - Dwarf Hybrid Varieties

hirsutum

Scarlet, very dwarf

8 to 12 in.

250

2200

myrtifolium

Red

18 to 24 in. .................... $300 \quad 2800$

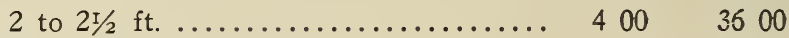

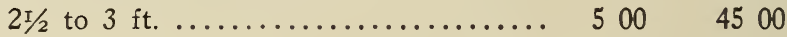

ovatum

Pink

15 to 18 in. ..................... 300

2700

18 to 24 in

$400 \quad 3600$

wilsoni

Pink

15 to 18 in

300

2700

18 to 24 in

400

24 to 30 in

500

\section{RHODODENDRON CAROLINIANUM}

Each

3600

(A native of high altitudes in the Southern Appalachian region.) One of the finest of all broad-leaved evergreens hardy in Massachusetts. Of compact habit growing from 4 to 6 feet tall and as much in diameter; foliage handsome dark-green and very floriferous; flowers pale to deep pink.

15 in. single stemmed plants ......... 200

1800

16000

18 in. single stemmed plants ...........

2 ft. bushy specimens

400

3600

$2 \mathrm{r} / 2 \mathrm{ft}$. bushy specimens

500

4500

\section{RHODODENDRON CATAWBIENSE (Native)}

Transplanted nursery stock, with good balls.

$2 \mathrm{ft}$. bushy specimens ............. 300

$2 \mathrm{I} / 2 \mathrm{ft}$. bushy specimens ........... 400

$3 \mathrm{ft}$. bushy specimens ............. 500

$3 \mathrm{r} / 2 \mathrm{ft}$. broad specimens ............ 600

\section{RHODODENDRON MAXIMUM (Native)}

Transplanted with good balls.

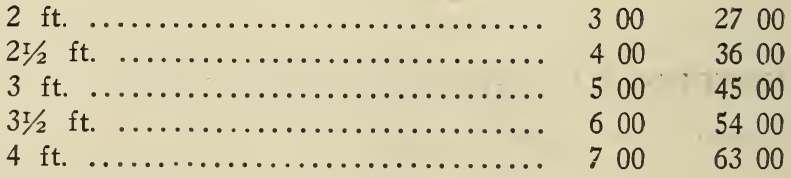

The above are fine specimens all transplanted.

Special quotations by the car load for collected plants.

See CONDITIONS OF SALE on page 2. 


\section{DECIDUOUS SHRUBS}

\section{MEDAL OF HONOR AWARDED US AT THE PANAMA-PACIFIC EXPOSITION IN 1915 FOR DECIDUOUS SHRUBS}

Our shrubs are grown with plenty of space in the nursery rows to insure good, vigorous growth, and they lift with strong roots: they are healthy and make quick development after planting.

ACANTHOPANAX (See Aralia)

Each Per 10 Per 100

ALMOND (See Prunus japonica)

ALTHEA (See Hibiscus)

AMELANCHIER botryapium Dwarf Juneberry

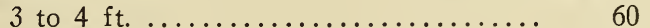

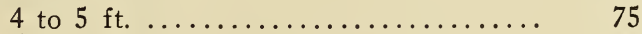

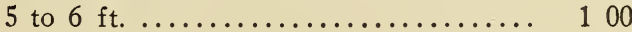

$500 \quad 4000$

$600 \quad 4800$

vulgaris

Shad Bush

3 to $4 \mathrm{ft}$.

60

$500 \quad 4000$

AMORPHA canescens

Lead Plant

2 to $3 \mathrm{ft}$

60

$500 \quad 4000$

fruticosa

False Indigo

4 to $5 \mathrm{ft} . \ldots \ldots \ldots \ldots \ldots \ldots \ldots \ldots \ldots$

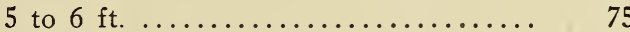

6 to $8 \mathrm{ft}$.

100

$500 \quad 4000$

$600 \quad 5000$

$800 \quad 6000$

ANDROMEDA paniculata

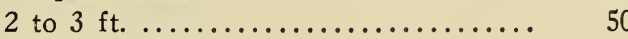

$450 \quad 4000$

pulverulenta or dealbata

2 to $3 \mathrm{ft} . \ldots \ldots \ldots \ldots \ldots \ldots \ldots \ldots \ldots, 100 \quad 900 \quad 8000$

Desirable for shady places.

ARALIA pentaphylla

Five-leaved Aralia

3 to $4 \mathrm{ft} . \ldots \ldots \ldots \ldots \ldots \ldots \ldots . . . \ldots$

$50 \quad 450$

3600

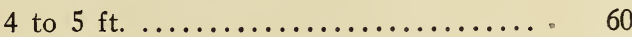

$540 \quad 4500$

5 to $6 \mathrm{ft}$.

80

700

6000

spinosa (See Deciduous Trees)

ARONIA arbutifolia

Red Chokeberry

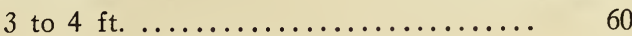

$500 \quad 4000$

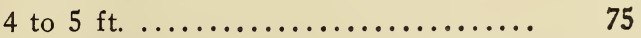

melanocarpa (nigra)

Black Chokeberry

2 to $3 \mathrm{ft}$

3 to $4 \mathrm{ft}$.

60

500

4000

AZALEA amoena (See Evergreen Shrubs)

arborescens

Fragrant Azalea

15 to 18 in. ...................... 175

$1600 \quad 14000$

18 to 24 in...................... 225

$2000 \quad 18000$

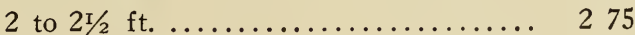

2500

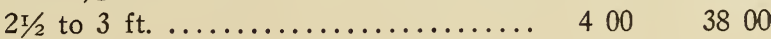


AZALEA - continued calendulacea

Each Per 10 . Per 100

18 to 24 in. ..................... 250

$2200 \quad 21000$

2 to $2 \mathrm{r} / 2$ ft. ...................... $300 \quad 2700$

25000

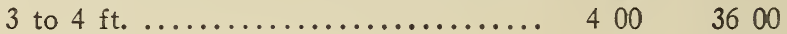

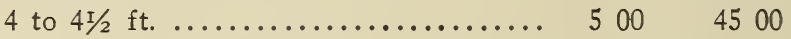

canadense

Canadian Rhodora

12 to 15 in. bushy ................. 150

1200

10000

15 to 18 in. bushy ................ 175

1500

18 to 24 in

225

2000

12000

canescens

Gray Azalea

18 to 24 in...................... $250 \quad 2200$

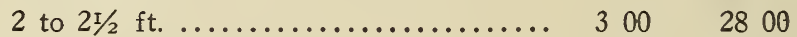

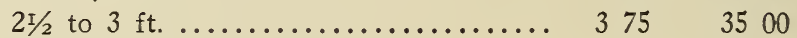

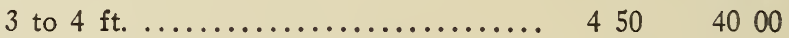

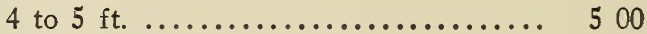

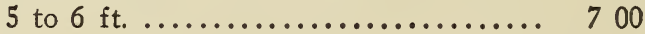

kaempferi

Japanese Flame Azalea

18 to 24 in...................... $200 \quad 1800$

$2 \mathrm{ft}$. bushy .................... 300

japonica (See Evergreen Shrubs)

mollis (mixed colors) Japanese Azalea

12 to 15 in....................... $125 \quad 1000$

15 to 18 in..................... $175 \quad 1500$

nudiflora

Pinxter Flower

15 to 18 in. ................... $200 \quad 1750$

18 to 24 in. .................... $275 \quad 2500$

pontica hybrida mixed Hybrid Ghent Azalea

18 to 24 in...................... $225 \quad 2000$

2 to $21 / 2 \mathrm{ft} . \ldots \ldots \ldots \ldots \ldots \ldots \ldots \ldots . \ldots . \ldots 275 \quad 2500$

vaseyi

Southern Azalea

15 to 18 in..................... 2 $50 \quad 2200$

18 to 24 in..................... 300

viscosa

Swamp Honeysuckle

18 to 24 in. .................... $200 \quad 1800$

16000

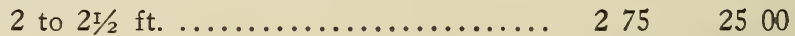

22500

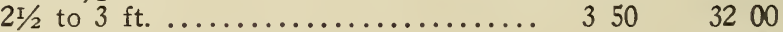

3 to $3 \mathrm{r} / 2 \mathrm{ft} . \ldots \ldots \ldots \ldots \ldots \ldots \ldots \ldots \ldots$. $450 \quad 4000$

yodogawa

$2 \mathrm{r} / 2 \mathrm{ft} . \mathrm{XX} \ldots \ldots \ldots \ldots \ldots \ldots \ldots \ldots \ldots \ldots \ldots$

BERBERIS ilicifolia

Holly-leaved Barberry

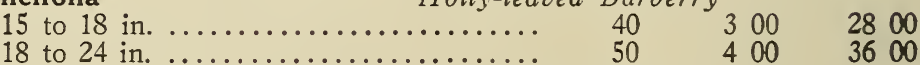

sieboldii

2 to $3 \mathrm{ft}$

Siebold's Barberry

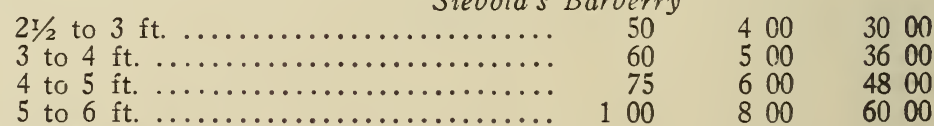

Foliage and berries larger than vulgaris. 
BERBERIS - continued

thunbergii

12 to 15 in.

15 to 18 in.

18 to 24 in.

2 to $2 \mathrm{r} / 2 \mathrm{ft}$.

$2 \mathrm{r} / 2$ to $3 \mathrm{ft}$.

vulgaris

2 to $3 \mathrm{ft}$.
3 to $4 \mathrm{ft}$.

vulgaris var. purpurea

2 to $3 \mathrm{ft}$

3 to $4 \mathrm{ft}$

4 to $5 \mathrm{ft}$.

5 to $6 \mathrm{ft}$.

\section{Each}

Japanese Barberry

Per 10 Per 100

1500

1800

$50 \quad 400 \quad 2400$

$60 \quad 500 \quad 3000$

$75 \quad 600 \quad 4800$

Common Barberry 
COLUTEA arborescens

5 to 6 ft.

Bladder Senna

Siberian Dogwood

CORNUS alba or siberica

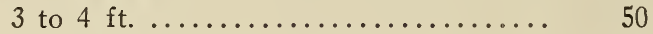

$50 \quad 400$

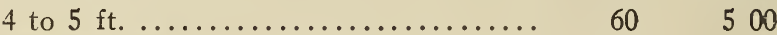

a. var. argentea marginata

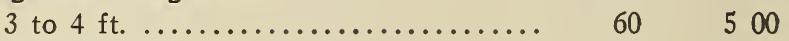

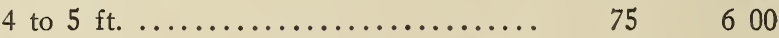

alternifolia

Blue Dogwood

\begin{tabular}{|c|c|c|}
\hline 3 to $4 \mathrm{ft} . \ldots \ldots \ldots \ldots \ldots \ldots$ & 50 & 400 \\
\hline 4 to $5 \mathrm{ft} . \ldots \ldots \ldots \ldots \ldots \ldots \ldots \ldots \ldots$ & 60 & 500 \\
\hline $\mathrm{ft} . \ldots \ldots \ldots \ldots \ldots \ldots \ldots \ldots \ldots$ & 75 & 600 \\
\hline $8 \mathrm{ft} . \ldots \ldots \ldots \ldots \ldots \ldots \ldots \ldots$ & 100 & 800 \\
\hline
\end{tabular}

circinata Round-leaved Dogwood

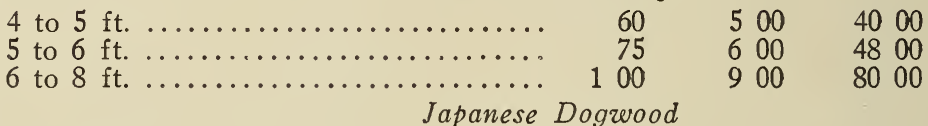

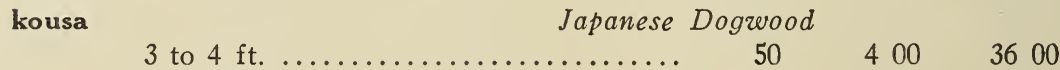

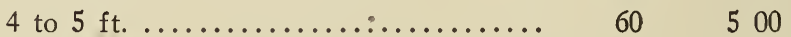

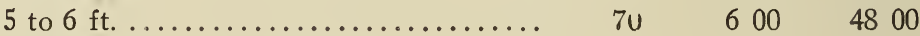

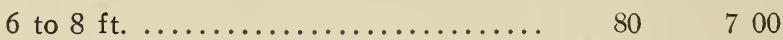

mascula Cornelian Cherry

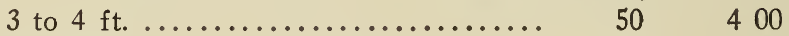

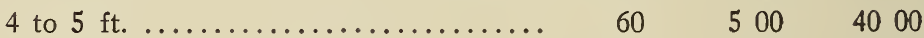

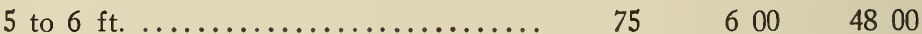

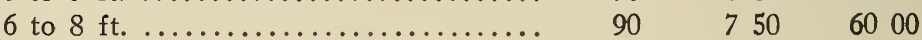

paniculata (racemosa) Gray Dogwood

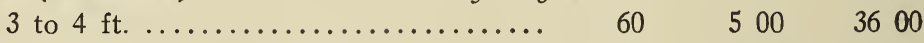

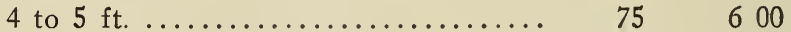

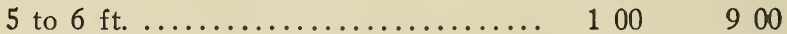

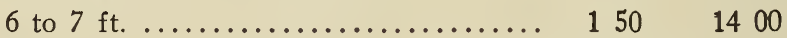

sanguinea

European Red Osier

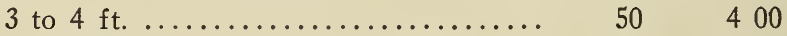

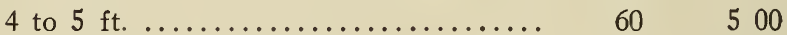

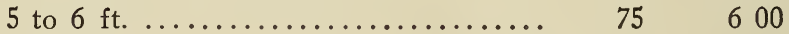

sericea (Amomum) Silky Cornel

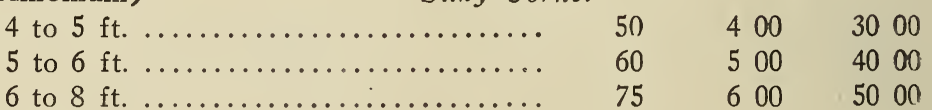

spaethi aurea

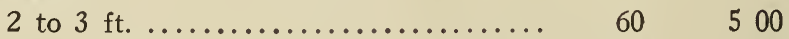

stolonifera

Native Red Osier

3 to $4 \mathrm{ft}$

$60 \quad 500$

3600

4 to $5 \mathrm{ft}$.

$75 \quad 600$

stolonifera var. flaviramea Golden-barked Dogwood

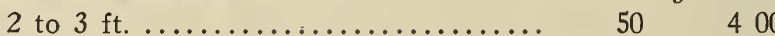

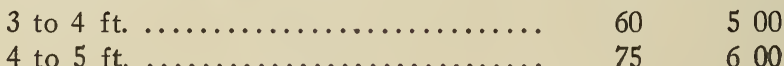

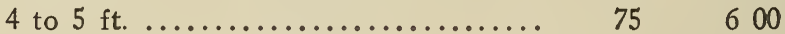


Each Per 10 Per 100

COTONEASTER simonsi - Simons' Rose Box

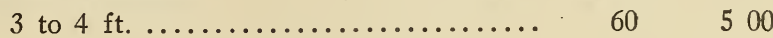

franchetii Tall Quince Berry

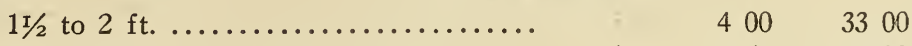

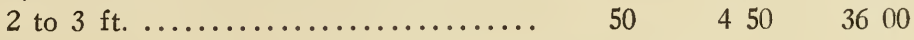

horizontalis Chinese Quince Berry.

15 to 18 in. ................... $50 \quad 400$

CYDONIA japonica Japanese Quince

2 to $3 \mathrm{ft} . \ldots \ldots \ldots \ldots \ldots \ldots \ldots \ldots . \ldots \ldots \ldots$

$450 \quad 4000$

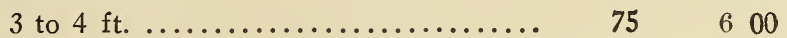

japonica var. rubra Red Japanese Quince

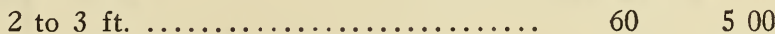

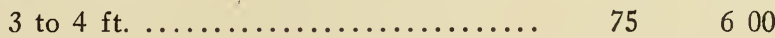

DEUTZIA crenata Single White Deutzia

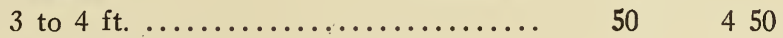

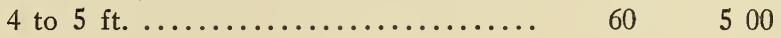

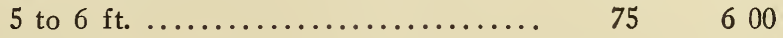

3900

c. var. pride of rochester

Pink Deutzia

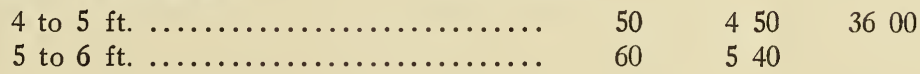

gracilis

Dwarf Deutzia

18 to 24 in. ....................... 50

$450 \quad 3600$

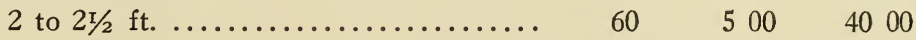

lemoinei

Lemoine's Deutzia

(one of the best: very floriferous)

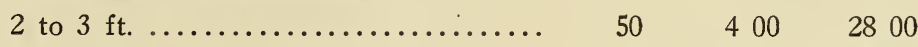

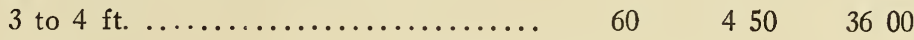

\section{DIERVILLA alba White Weigela}

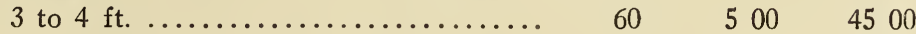

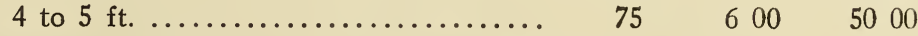

hybrida candida White Weigela

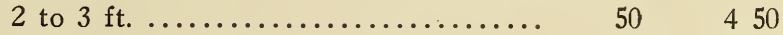

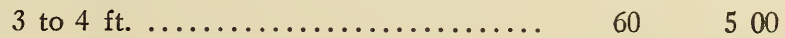

h. desbosi (deep rose)

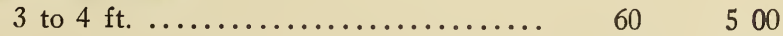

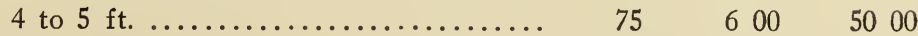

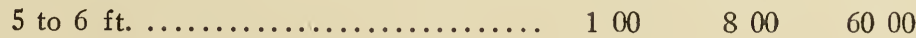


DIERVILLA - continued

h. eva rathke

Each Per 10 Per 100

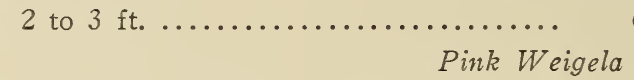

Carmine Weigela

rosea

18 to 24 in. bushy ................ 50

3600

3 to $4 \mathrm{ft} . \ldots \ldots \ldots \ldots \ldots \ldots \ldots \ldots . \ldots \ldots$

450

var. floribunda

Red Weigela

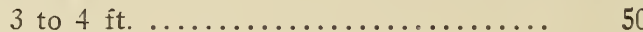

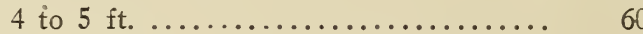

450

3600

var. rosea variegata

Variegated Weigela

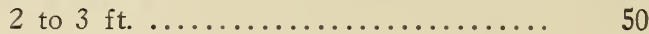

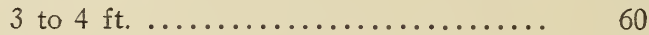

3600

4 to $5 \mathrm{ft} . \ldots \ldots \ldots \ldots \ldots \ldots \ldots \ldots \ldots \ldots . \ldots \ldots$

500

600

trifida

Yellow Weigela

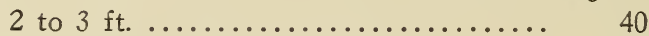

300

2400

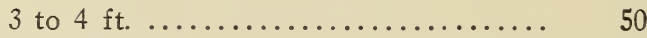

400

2800

ELEAGNUS angustifolia

Russian Oleaster

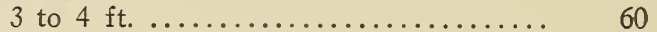

500

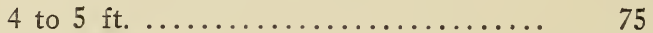

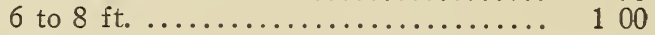

longipes

Japanese Oleaster

2 to $3 \mathrm{ft}$.

50

450

4000

EUONYMUS alata

Cork-barked Euonymus

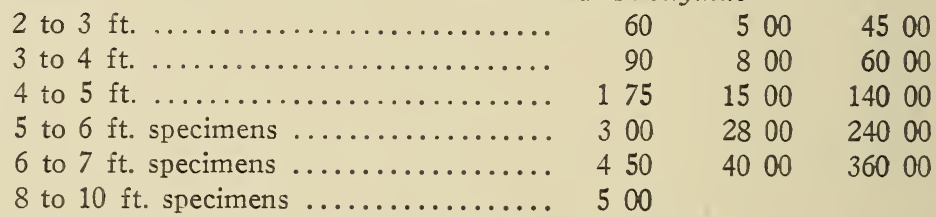

The above is a rare shrub of exceeding beauty.

bungeanus

Bunge's Burning Bush

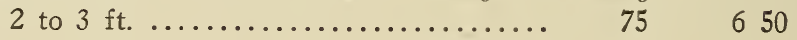

europaea

Strawberry Tree

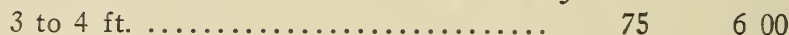

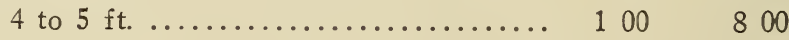

latifolia Broad-leaved Spindle Tree

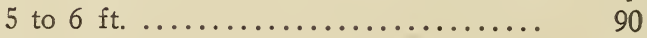

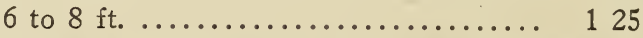

A decorative variety with handsome foliage and large fronds. nana

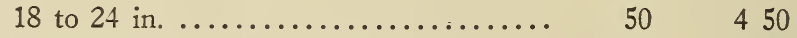

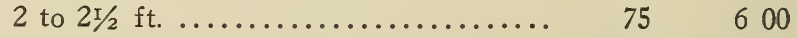

obovata

Prostrate Spindle Tree

12 to 18 in. .................... 50

EXOCHORDA grandiflora Pearl Bush

2 to 3 ft. ..................... $50 \quad 400 \quad 3000$ 
FORSYTHIA intermedia

3 to $4 \mathrm{ft}$

4 to $5 \mathrm{ft}$.

5 to $6 \mathrm{ft}$.

Each Per 10

Per 100

Golden Bell

$\begin{array}{lllll}50 & 4 & 00 & 30 & 00 \\ 60 & 5 & 00 & 40 & 00 \\ 75 & 6 & 00 & 4500\end{array}$

suspensa

Drooping Golden Bell

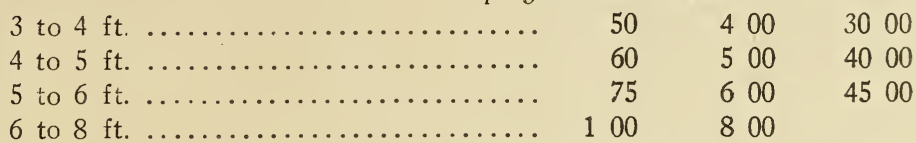

var. fortunei

Fortune's Golden Bell

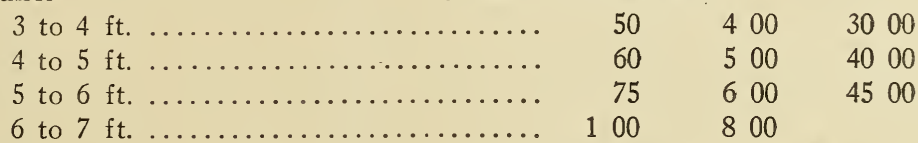

var. sieboldi

Siebold's Golden Bell

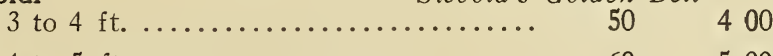

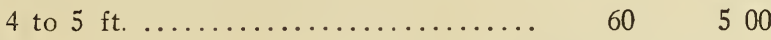

4000

viridissima

Green-twigged Golden Bell

3 to $4 \mathrm{ft} . \ldots \ldots \ldots \ldots \ldots \ldots \ldots \ldots . \ldots \ldots \ldots$

3000

4 to $5 \mathrm{ft}$

$60 \quad 500$

4000

GENISTA tinctoria

2 to $3 \mathrm{ft}$

Dyer's Greenweed

$400 \quad 3600$

GLEDITSCHIA (Honey Locust) See under Trees

HALESIA carolina

Silver Bell

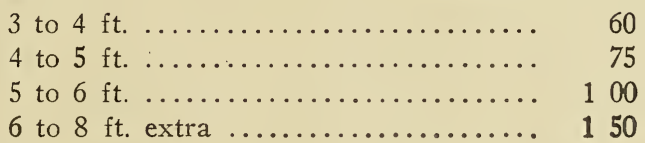

HAMAMELIS virginiana Witch Hazel

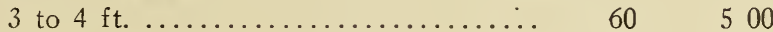

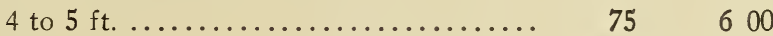

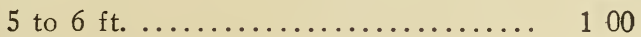

HIBISCUS syriacus Althea or Rose of Sharon

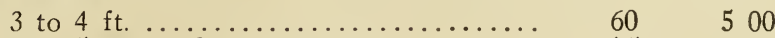

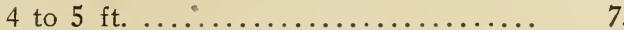

Colors:-Double red, double pink, double white, single white, double bicolor, single bicolor, and single pink with dark center.

HYDRANGEA arborescens

Wood Hydrangea

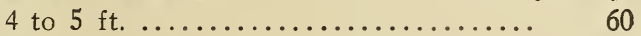

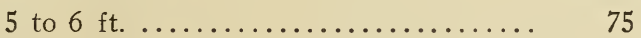

arborescens grand. alba

Snowball Hydrangea

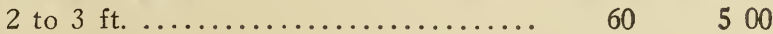

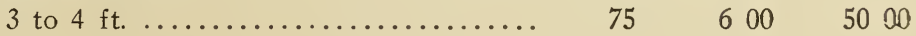


HYDRANGEA - continued

Each Per 10 Per 100

paniculata (type)

2 to $3 \mathrm{ft}$.

Single-flowered Hydrangea

3 to $4 \mathrm{ft}$.

50

400

3600

60

500

4000

paniculata var. grandiflora

Common Hydrangea

2 to $3 \mathrm{ft}$.

60

500

4000

3 to $4 \mathrm{ft}$.

75

600

Standards 3 to $4 \mathrm{ft}$.

90

5000

radiata or nivea

Silvery Hydrangea

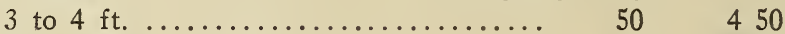

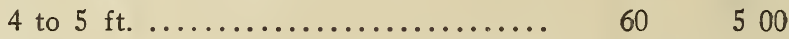

ILEX verticillata

Winterberry or Black Alder

2 to $3 \mathrm{ft}$.

60

500

4200

3 to $4 \mathrm{ft}$.

75

600

5000

ITEA virginica

Virginia Willow

18 to 24 in. .................... 50

450

KERRIA japonica

2 to $2 \mathrm{~T} / 2 \mathrm{ft}$

Globe Flower

50

450

4000

var. argentea variegata

Variegated Globe Flower

15 to 18 in.

var. flora plena

$50 \quad 400$

18 to $24 \mathrm{in}$.

Double Globe Flower

$60 \quad 500$

\section{LESPEDEZA sieboldi}

3 yrs.

$60 \quad 500$

LIGUSTRUM amurense

4 moor River Privet

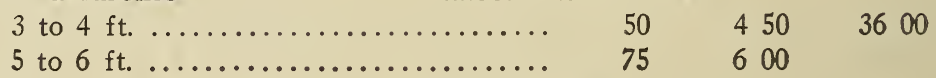

ibota

Chinese Privet

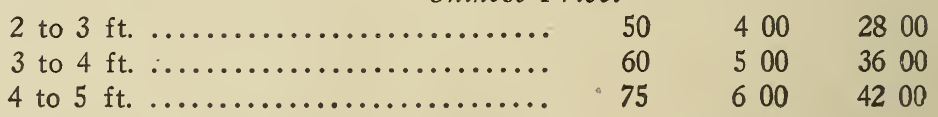

var. regelianum

Regel's Privet

18 to 24 in. ....................... 50

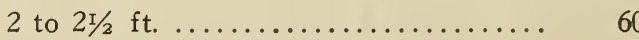

$50 \quad 400 \quad 2800$

$2 \mathrm{t} / 2$ to $3 \mathrm{ft}$

60

$450 \quad 3600$

$600 \quad 4000$

ovalifolium

2 to $3 \mathrm{ft} \ldots \ldots \ldots \ldots \ldots \ldots \ldots \ldots \ldots$

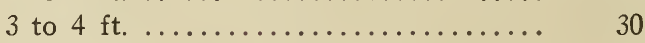

$180 \quad 1000$

4 to $5 \mathrm{ft}$.

$30 \quad 220$

1200

vulgare

European Privet

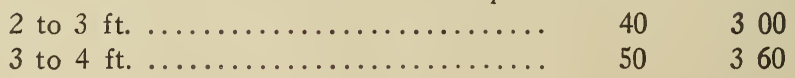


LONICERA bella albida

$$
3 \text { to } 4 \mathrm{ft} \text {. }
$$

fragrantissima

$$
\begin{aligned}
& 2 \text { to } 3 \mathrm{ft} \text {. } \\
& 3 \text { to } 4 \mathrm{ft} \text {. }
\end{aligned}
$$

morrowii

$$
\begin{aligned}
& 3 \text { to } 4 \mathrm{ft} \\
& 4 \text { to } 5 \mathrm{ft} \\
& 5 \text { to } 6 \mathrm{ft}
\end{aligned}
$$

ruprechtiara

$$
3 \text { to } 4
$$

4 to $5 \mathrm{ft}$.

5 to $6 \mathrm{ft}$

6 to $8 \mathrm{ft}$

standishi
White Honeysuckle

Each Per 10 Per 100

$\begin{array}{lll}50 & 400 \quad 3000\end{array}$

Fragrant Bush Honeysuckle

$50 \quad 400$

$60 \quad 500$

Japanese Bush Honeysuckle

$50 \quad 400$

$60 \quad 500$

$75 \quad 600$

Manchurian Honeysuckle

50400

3000

$60 \quad 500$

3600

$70 \quad 600$

4500

$90 \quad 800$

Standish's Honeysuckle
2 to $3 \mathrm{ft}$
50
400
3 to $4 \mathrm{ft}$
60
500

tatarica alba

White Tatarian Honeysuckle

3 to $4 \mathrm{ft}$ $50 \quad 400$

\section{tatarica rosea}

3 to $4 \mathrm{ft}$

4 to $5 \mathrm{ft}$

\section{Tatarian Honeysuckle}

$50 \quad 450$

3600

$60 \quad 500$

MYRICA cerifera

Candleberry

15 to 18 in. ..................... 50

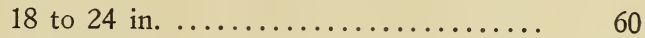

$400 \quad 3600$

24 to 30 in.

gale

Bayberry

18 to $24 \mathrm{in}$.

50

450

\section{NEMOPANTHUS mucronata}

Mountain Holly

3 to $4 \mathrm{ft}$.

$60 \quad 500$

4 to $5 \mathrm{ft}$.

75

600

\section{PHILADELPHUS coronarius}

Syringa or Mock Orange

3 to $4 \mathrm{ft}$.

4 to $5 \mathrm{ft}$.

5 to $6 \mathrm{ft}$.
50

60

75
400

500

600
3000

3600 4500

c. follis aurea

Golden Syringa

12 to 15 in

18 to 24 in. 


\section{PHILADELPHUS - continued}

c. var. nana

18 to 24 in

2 to $3 \mathrm{ft}$.

gordonianus

3 to $4 \mathrm{ft}$

4 to $5 \mathrm{ft}$.

5 to $6 \mathrm{ft}$

6 to $8 \mathrm{ft}$.

grandiflorus

3 to $4 \mathrm{ft}$

4 to $5 \mathrm{ft}$

5 to $6 \mathrm{ft}$

6 to $7 \mathrm{ft}$

lemoinei

2 to $3 \mathrm{ft}$

3 to $4 \mathrm{ft}$

lemoinei hybrida

Avalanche

3 to $4 \mathrm{ft}$.

4 to $5 \mathrm{ft}$.
Each Dwarf Mock Orange

Per 10 Per 100 50 75

Gordon's Syringa

$\begin{array}{llll}50 & 400 & 3000 \\ 60 & & 500 & 3600 \\ 75 & 600 & 4500 \\ 00 & 900 & & \end{array}$

Large-flowered Syringa

$\begin{array}{llll}50 & 400 & 30 & 00 \\ 60 & & 500 & 3600 \\ 75 & 600 & 4500 \\ 00 & 900 & & \end{array}$

Lemoine's Mock Orange

$60 \quad 450$

3600

$75 \quad 500 \quad 4000$

Lcmoine's Hybrid Mock Oranges

$60 \quad 500 \quad 4000$

$75 \quad 600 \quad 4500$

A very desirable dwarf shrub.

Mont Blanc

2 to $3 \mathrm{ft} . \ldots \ldots \ldots \ldots \ldots \ldots \ldots \ldots \ldots$

3 to $4 \mathrm{ft} . \ldots \ldots \ldots \ldots \ldots \ldots \ldots \ldots \ldots \ldots . \ldots \ldots$

$50 \quad 450 \quad 3600$

$60 \quad 500 \quad 4000$

POTENTILLA fruticosa

Cinquefoil

2 to $3 \mathrm{ft} . \ldots \ldots \ldots \ldots \ldots \ldots \ldots \ldots \ldots \ldots \ldots \ldots \ldots \ldots \ldots \ldots \ldots \ldots \ldots \ldots \ldots$
3 to $4 \mathrm{ft} . \ldots \ldots \ldots \ldots \ldots \ldots$

PRUNUS japonica alba plena

2 to $3 \mathrm{ft}$.

Double White Almond

3 to $4 \mathrm{ft}$.

60

500

4000

maritima

Beach Plum

2 to $3 \mathrm{ft} . \ldots \ldots \ldots \ldots \ldots \ldots \ldots \ldots \ldots \ldots \ldots \ldots \ldots \ldots \ldots \ldots \ldots \ldots \ldots \ldots$
3 to $4 \mathrm{ft} . \ldots \ldots \ldots \ldots \ldots \ldots$

tomentosa

Chinese Cherry

4 to $5 \mathrm{ft}$

$50 \quad 400$

5 to $6 \mathrm{ft}$.

60

triloba

Double Flowering Plum
3 to $4 \mathrm{ft}$.
60
500

virginiana

Chokecherry

4 to 5

50

400

5 to $6 \mathrm{ft}$.

60

500

6 to $8 \mathrm{ft}$. 


\section{RHAMNUS caroliniana}

3 to $4 \mathrm{ft}$.

4 to $5 \mathrm{ft}$.

6 to $8 \mathrm{ft}$.
Carolina Buckthorn

$50 \quad 400$

$60 \quad 500$

$75 \quad 600$

carthartica

Common Buckthorn

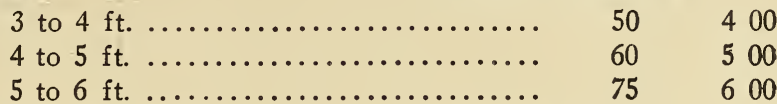

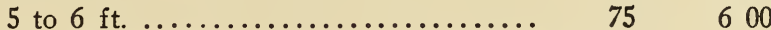

\section{RHODOTYPOS kerrioides White Kerria}

2 to $3 \mathrm{ft}$

$400 \quad 3000$

3 to $4 \mathrm{ft} . \ldots \ldots \ldots \ldots \ldots \ldots \ldots \ldots \ldots \ldots . \ldots \ldots$

RHUS canadensis (aromatica) Fragrant Sumac

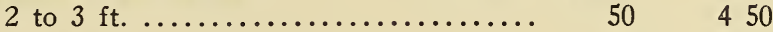

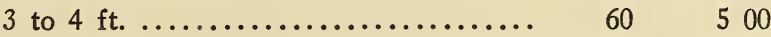

3600

copallina

Shining Sumac

2 to $3 \mathrm{ft} . \ldots \ldots \ldots \ldots \ldots \ldots \ldots \ldots \ldots \ldots \ldots \ldots \ldots \ldots \ldots \ldots \ldots \ldots \ldots \ldots \ldots \ldots \ldots$
3 to $4 \mathrm{ft} . \ldots \ldots \ldots \ldots \ldots \ldots$

cotinus

Smoke Bush

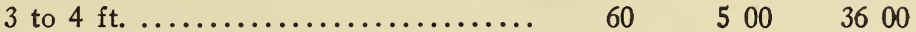

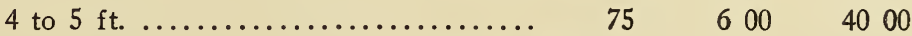

glabra

Smooth Sumac

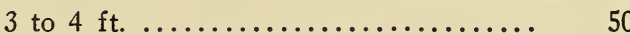

$50 \quad 400 \quad 3600$

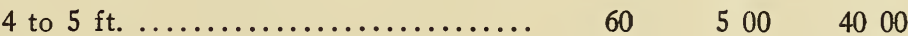

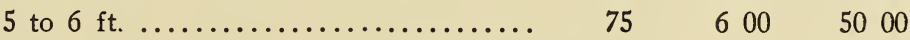

var. laciniata

3 to $4 \mathrm{ft}$.

typhina

4 to 5 ft.

4 to $5 \mathrm{ft}$.

5 to $6 \mathrm{ft}$.

6 to $8 \mathrm{ft}$.

var. laciniata

2 to $3 \mathrm{ft}$.

Cut-leaved Sumac

60

Staghorn Sumac

ROBINIA hispida

2 to $3 \mathrm{ft}$.

3 to $4 \mathrm{ft}$.

ROSA blanda

2 to $3 \mathrm{ft}$.

carolina

Meadow Rose

Rose Acacia

Swamp Rose

$90 \quad 800$

Cut-leaved Staghorn Sumac

$60 \quad 500$

2 to $3 \mathrm{ft}$.

$50 \quad 400$

$60 \quad 500$

3000

$50 \quad 400 \quad 3000$

lucida

Wild Rose

3 to $3 \mathrm{r} / 2 \mathrm{ft}$.

multiflora

Japanese Climbing Rose

$400 \quad 3000$

$400 \quad 3000$

3 to $4 \mathrm{ft}$. 
ROSA - continued

nitida

Each Per 10 Per 100 Shining-leaved Rose

18 to 24 in.

50

$400 \quad 3000$

rubiginosa

Sweet Briar Rose

2 to $3 \mathrm{ft}$.

50

400

rubrifolia

Red-leaved Rose

2 to $3 \mathrm{ft}$

$400 \quad 3000$

rugosa

Japanese Rose

18 to 24 in. ...................... 50

2 to $3 \mathrm{ft} . \ldots \ldots \ldots \ldots \ldots \ldots \ldots \ldots . .6 \%$

$450 \quad 4000$

3 to $4 \mathrm{ft}$.

75

$500 \quad 450$ ?

rugosa alba

White Japanese Rose

15 to 18 in...................... $60 \quad 500$

setigera

Prairie Rose

2 to $3 \mathrm{ft}$

350

2700

3 to $4 \mathrm{ft}$

50

3200

wichuraiana

Memorial Rose

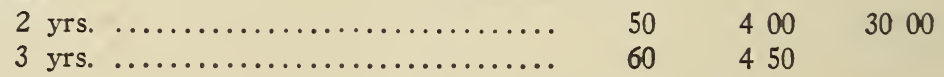

RUBUS odoratus

Flowering Raspberry

3 to $4 \mathrm{ft}$.

$50 \quad 360$

2800

SAMBUCUS canadensis

Elderberry

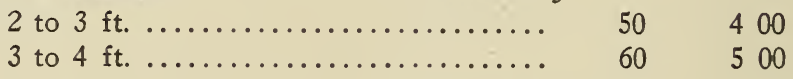

nigra var. aurea

Golden Elder

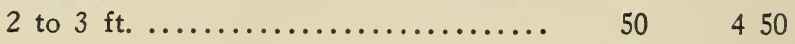

racemosus

Red-berried Elder

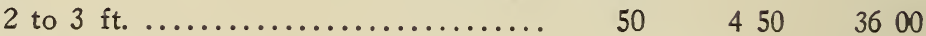

SPIRAEA arguta

Hybrid Snow Garland

2 to $3 \mathrm{ft}$

$50 \quad 450$

3600

3 to $4 \mathrm{ft}$.

60

500

4000

billardi

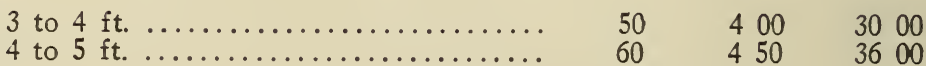

bumalda

Pink Everblooming Spiraea
2 to $3 \mathrm{ft}$.
60
500
4000

b. var. anthony waterer

Crimson Everblooming Spiraea

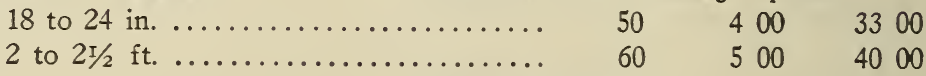

callosa

Fortune's Spiraea

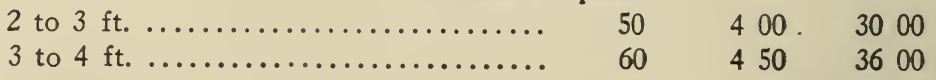


SPIRAEA - continued

callosa var. alba

18 to 24 in.

2 to $3 \mathrm{ft}$.
Eac

Fortune's White Spiraea

$\begin{array}{llll}50 & 400 & 3000 \\ 60 & 450 & 3600\end{array}$

c. var. superba

18 to 24 in

50

60

400

3000

2 to $3 \mathrm{ft}$.

lanceolata

2 to $3 \mathrm{ft}$

50

60

400

450

3000

3 to $4 \mathrm{ft}$

Nine Bark

4 to $5 \mathrm{ft}$

500

600

5 to 6

6 to $7 \mathrm{ft}$

90

3600

o. var. aurea

Golden Nine Bark

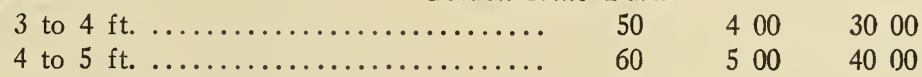

prunifolia flora pleno

2 to $3 \mathrm{ft}$

3 to $4 \mathrm{ft}$

reevesii

Bridal Wreath

$60 \quad 500$

4000

Reeve's Spiraea

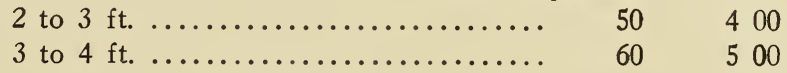

sorbifolia

Ash-leaved Spiraea

2 to $3 \mathrm{ft}$

50

400

3000

thunbergii

Snow Garland

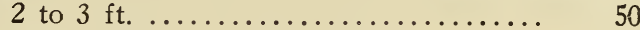

3 to $4 \mathrm{ft} . \ldots \ldots \ldots \ldots \ldots \ldots \ldots \ldots \ldots \ldots . \ldots \ldots \ldots$

$400 \quad 3000$
50

4 to $5 \mathrm{ft}$.

60

$500 \quad 3600$

$600 \quad 4000$

van houttei

Bridal Bower

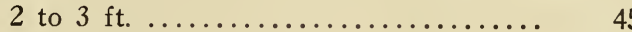

3 to $4 \mathrm{ft} . \ldots \ldots \ldots \ldots \ldots \ldots \ldots \ldots \ldots$

\begin{tabular}{l}
$400 \quad 3000$ \\
\hline
\end{tabular}

4 to $5 \mathrm{ft}$.

60

$450 \quad 3600$

NDRA flexuosa Lace Shrub

3 to $4 \mathrm{ft}$.

60

500

SYMPHORICARPOS racemosus

Snowberry

2 to $3 \mathrm{ft}$.

vulgaris

Indian Currant

3 to $4 \mathrm{ft}$. 
SYRINGA japonica (See Deciduous Trees)

Each

Per 10 Per 100 josikaea

Hungarian Lilac

5 to $6 \mathrm{ft} . \ldots \ldots \ldots \ldots \ldots \ldots \ldots \ldots \ldots . \ldots \ldots$

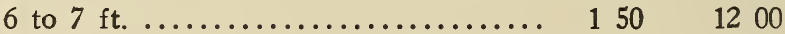

pekinensis

Chinese Lilac

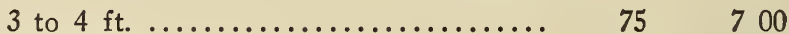

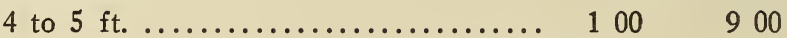

persica

Persian Lilac

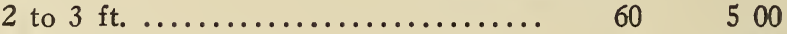

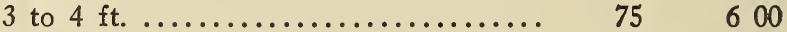

rothomagensis

Red Persian Lilac

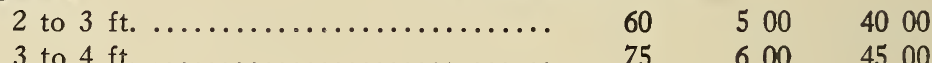

villosa

Himalayan Lilac

2 to $3 \mathrm{ft} . \ldots \ldots \ldots \ldots \ldots \ldots \ldots \ldots \ldots \ldots .6 \ldots \ldots$

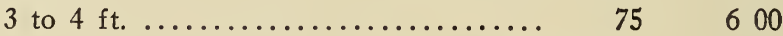

vulgaris

Common Lilac

3 to $4 \mathrm{ft} . \ldots \ldots \ldots \ldots \ldots \ldots \ldots \ldots$

4 to $5 \mathrm{ft} . \ldots \ldots \ldots \ldots \ldots \ldots \ldots \ldots \ldots \ldots \ldots, 100,800 \quad 7000$

vulgaris var. alba

Common White Lilac

3 to $4 \mathrm{ft}$.

$75 \quad 600$

4500

4 to $5 \mathrm{ft}$.

100

5 to $6 \mathrm{ft}$.

150

6 to $7 \mathrm{ft}$.

200

$800 \quad 7000$

$1400 \quad 12000$

\section{HYBRID LILACS}

Alba grandiflora (Large, single white)

2 to $3 \mathrm{ft}$.

$90 \quad 800$

6500

3 to $4 \mathrm{ft}$.

$125 \quad 1100$

Charles $\mathrm{X}$ (Single, reddish purple)

2 to $3 \mathrm{ft}$.

3 to $4 \mathrm{ft}$.

Dr. Lindley (Purplish lilac)

2 to $3 \mathrm{ft}$.

Jacques Calot (Single rose pink)

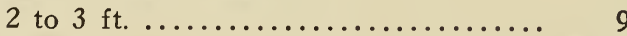

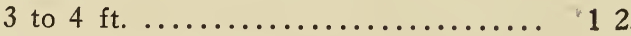

$90 \quad 800$

6500

Arc (Double white)

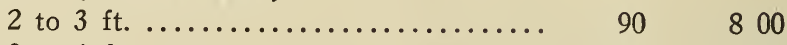

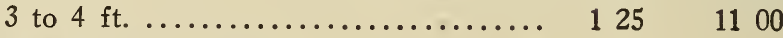

Marie Legraye (Single white)

2 to $3 \mathrm{ft}$.

M. Buchner (Double pale lilac)

2 to $3 \mathrm{ft}$. 
HYBRID LILACS - Continued

Each Per 10 Per 100

Mme. Casimer Perier (Double cream white)
2 to $3 \mathrm{ft}$.
800
6500
3 to $4 \mathrm{ft}$.
125
1100
9000

Mme. Lemoine (Large double white)

\begin{tabular}{|c|c|c|}
\hline 2 to $3 \mathrm{ft} . \ldots \ldots \ldots \ldots$ & 90 & 800 \\
\hline$\ldots \ldots, \ldots, \ldots, \ldots, \cdots$, & 125 & 1100 \\
\hline to $5 \mathrm{ft}$. . & 175 & 1400 \\
\hline to $6 \mathrm{ft} \quad-$ & 250 & 2000 \\
\hline
\end{tabular}

President Grevy (Blue)

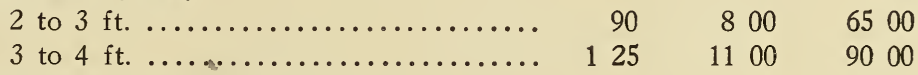

Rubra de Marley (Single rosy purple)

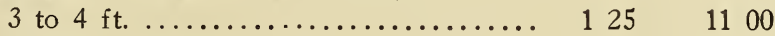

Senateur Volland (Double red)

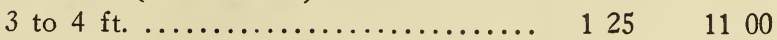

S. de L. Spaeth (Single dark red)
2 to $3 \mathrm{ft}$.
6500
3 to $4 \mathrm{ft}$.
125
1100
9000
4 to $5 \mathrm{ft}$
$175 \quad 1400$

\section{STANDARD HYBRIDS}
3 to $4 \mathrm{ft}$. stems
200
1800

Varieties:-C. B. Van Ness, Charles Joly-double; dark lilac-red. Charles $\mathrm{X}$-single; reddish purple. Jeanne d'Arc-double; pure white. Marie Legraye-single; large white. Michael Buchner-double; pale-lilac. Mme. Casimer Perier-double; cream-white. Mme. Lemoine-double; white. President Grevy-double; large blue. Souv. de L-Spaethsingle; dark red. Valdet Trosseau, Volcan.

TAMARIX africana

2 to $3 \mathrm{ft}$ African Tamarisk

$60 \quad 500$

\section{VACCINIUM corymbosum}

3 to $4 \mathrm{ft}$. heavy

Blueberry

\section{VIBURNUM acerifolium}

$1 \mathrm{r} / 2$ to $2 \mathrm{ft}$.

americanum

3 to $4 \mathrm{ft}$

4 to $5 \mathrm{ft}$.

cassinoides

2 to $3 \mathrm{ft}$

3 to $4 \mathrm{ft}$.

4 to $5 \mathrm{ft}$.

5 to $6 \mathrm{ft}$.

6 to $7 \mathrm{ft}$.

Maple-leaved Viburnum

$150 \quad 1200 \quad 10000$ $50 \quad 450 \quad 4000$

American High Bush Cranberry

$50 \quad 420 \quad 3600$

$60 \quad 500 \quad 4500$

Withe Rod

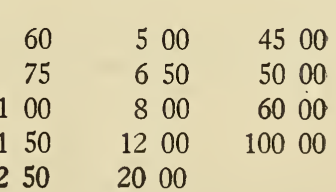


VIBURNUM - continued

dentatum

Each Per 10

Per 100

Arrowwood

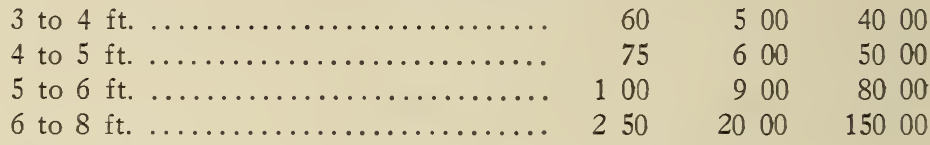

dilatatum

Japanese Bush Cranberry

3 to $4 \mathrm{ft} . \ldots \ldots \ldots \ldots \ldots \ldots \ldots . \ldots \ldots$. $120 \quad 1000$

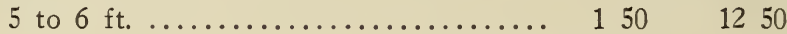

lantana

Wayfaring Tree

3 to $4 \mathrm{ft}$. . . 60

4 to $5 \mathrm{ft}$

75

500

3600

Sheep Berry

lentago

3 to $4 \mathrm{ft}$

60

600

4500

4 to $5 \mathrm{ft}$.

75

500

4000

5 to $6 \mathrm{ft}$

100

600

5000

6 to $7 \mathrm{ft}$.

150

800

7000

molle

Silky Viburnum

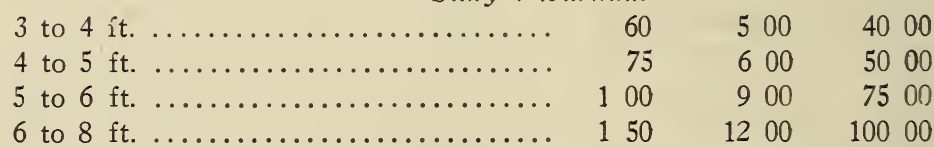

opulus

High Bush Cranberry

\begin{tabular}{|c|c|c|}
\hline 3 to $4 \mathrm{ft} . \ldots \ldots \ldots \ldots$ & 60 & 500 \\
\hline 4 to $5 \mathrm{ft} . \ldots \ldots \ldots$ & 75 & 600 \\
\hline ft. $\ldots \ldots \ldots \ldots \ldots \ldots \ldots \ldots \ldots \ldots \ldots$ & 90 & 750 \\
\hline ft. $\ldots \ldots \ldots \ldots \ldots \ldots \ldots \ldots \ldots \ldots$ & 100 & 900 \\
\hline
\end{tabular}

opulus var. sterile

Common Snowball

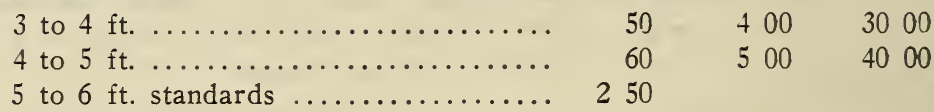

sieboldii syn. japonicum

Siebold's Viburnum

3 to $4 \mathrm{ft} . \ldots \ldots \ldots \ldots \ldots \ldots \ldots \ldots . \ldots \ldots$

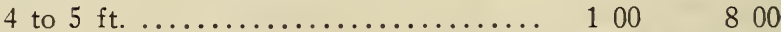

tomentosum

Single Japanese Snowball

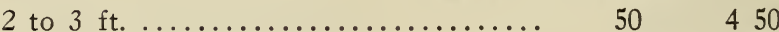

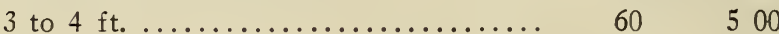

4000

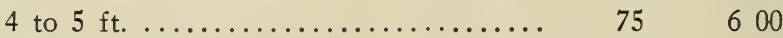

t. var. plicatum

Japanese Snowball

3 to $4 \mathrm{ft}$.

75

600

5000

$90 \quad 800 \quad 7000$

WEIGELA (See Diervilla)

XANTHORRHIZA apifolia

Yellow Root

12 to 15 in

$350 \quad 2700$

15 to 18 in.

$400 \quad 3600$

18 to 24 in

50

450

4000 


\section{VINES AND CLIMBING PLANTS}

ACTINIDIA arguta

3 yrs. 4 to $5 \mathrm{ft}$

AKEBIA quinata

3 yrs.

AMPELOPSIS quinquefolia

2 yrs.

3 yrs.

engelmanni

3 yrs.

4 yrs.

veitchi

2 yrs.

2 yrs.

ARISTOLOCHIA
Actinidia

Each

100

\section{Akebia}

Virginia Creeper

75
40

50

300

2700

400

3000

Clinging Virginia Creeper

$50 \quad 450$

$60 \quad 500$

3200

3600

Boston Ivy

sipho

6 yrs.

50

350

2700

900

\section{BIGNONIA (See Tecoma)}

CELASTRUS orbiculatus

Japanese Bittersweet

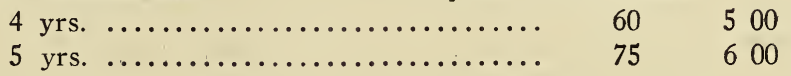

scandens

Bittersweet

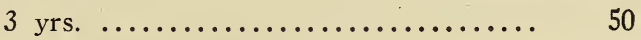

75

Scarlet Clematis

CLEMATIS coccinea

2 yrs.

60

500

crispa

aniculata

2 yrs.

2 yrs.

Japanese Clematis

50

American Clematis

2 yrs.

......... 50

400

600

3600

4800

virginiana

400

3300

\section{CLEMATIS HYBRIDS}

Large-flowering Clematis

2 yrs.

90

800

Duchess of Edinburg (Double white)

Henryii (Creamy white)

Jackmanii (Purple)

Mme. Edouard Andre (Crimson)

Ramona (Light blue)

DOLICHOS japonicus (Pueraria Thunbergiana)

2 yrs.

English Ivy

HEDERA helix

4 in. pots

Kudzu Vine

$50 \quad 400$ 
Each Per 10 Per 100

LONICERA belgica Monthly Fragrant Honeysuckle

3 yrs.

$50 \quad 400$

2700

flava

Yellow Honeysuckle

4 yrs. extra ................... $50 \quad 400$

japonica

Japanese Honeysuckle

3 yrs. ..................... $50 \quad 400 \quad 2700$

var. aurea reticulata

Golden Honey'suckle

4 yrs. ........................ $50 \quad 400 \quad 2700$

var. halleana

Hall's Evergreen Honeysuckle

3 yrs. ........................ $50 \quad 400 \quad 2700$

sempervirens

Scarlet Trumpet Honeysuckle

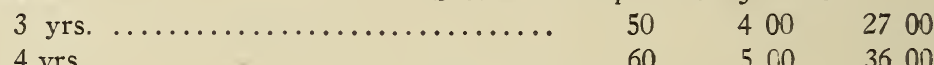

LYCIUM chinensis Matrimony $V$ ine

3 yrs. ...................... $50 \quad 400 \quad 2700$

PERIPLOCA graeca Silk Vine

4 yrs. ........................ 75

SCHIZOPHRAGMA hydrangeoides Climbing Hydrangea

4 yrs. ...................... 400

TECOMA (bignonia) radicans Trumpet Vine

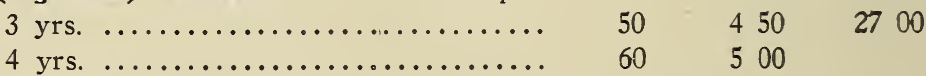

VITIS aestavalis $\quad$ Summer Grape

4 yrs. ...................... $75 \quad 600$

coignetia Crimson Glory Vine

3 yrs.......................... $75 \quad 600$

cordifolia Frost Grape

4 yrs. .......................... $75 \quad 600$

heterophylla Japanese Grape

4 yrs. ........................ $75 \quad 600$

labrusca Fox Grape

4 yrs. ........................... $75 \quad 600$

WISTARIA chinensis Chinese Blue Wistaria 5 yrs. ....................... $100 \quad 900$

c. var. alba

Chinese White Wistaria

5 yrs. ................................... $100 \quad 900$

extra large, 8 to $10 \mathrm{ft} . \ldots \ldots \ldots \ldots \ldots 200 \quad 1600$

frutescens

American Wistaria

5 yrs. ........................ $100 \quad 900$

f. var. magnifica Durple Wistaria

multijuga Japanese Wistaria

5 yrs. ...................... $100 \quad 900$

5 yrs. ........................ $100 \quad 900$

See CONDITIONS OF SALE on page 2. 


\section{HARDY ROSES}

Strong field grown plants, $\$ 100$ each for less than 5 of one kind; 5 or more of one kind, at $\$ 850$ for $10 ; 40$ or more in lots of not less than 10 of one kind, at $\$ 7500$ per 100 .

If we are out of the variety ordered, we shall select the variety most closely mesembling it UNLESS O'THERWISE ADVISED.

\section{HYBRID PERPETUAL ROSES}

Alfred Colomb-Large carmine-crimson, full, fragrant.

American Beauty-Rich, rosy crimson.

Anne de Diesbach-Large double carmine.

Baron de Bonstettin-Velvety maroon, large and full.

Baroness Rothschild-Large, pale rose.

Clio-Large, flesh color, center rosy pink.

Frau Karl Druschki-Pure white.

General Jacqueminot-Bright scarlet crimson.

Gloire de Chedane Guinoisseau-Bright vermillion-red, large.

Harrison Yellow-Yellow.

Hugh Dickson-Brilliant crimson shaded with scarlet.

John Hopper-Bright rose, carmine center.

Magna Charta-Pink and carmine.

Margaret Dickson-White, pale flesh center, large.

Mme. Gabriel Luizet-Light silver pink.

M. P. Wilder-Cherry carmine.

Mrs. John Laing-Large, soft pink; fragrant and steady bloomer.

Mrs. R. G. Sharman-Crawford-Deep rosy pink.

Paul Neyron-Deep rose, very large.

Persian Yellow-Yellow.

Prince Camille de Rohan-Deep velvety crimson.

Soleil d'Or-Deep yellow, shaded with orange and red.

Ulrich Brunner-Cherry crimson, large.

White Moss-White.

\section{HYBRID TEA ROSES}

Betty-Large, coppery rose, shaded golden-yellow.

British Queen-Large white.

Dean Hole-Silvery carmine, shaded salmon.

Edward Mawley-Velvety crimson.

Etoile de France-Rich velvety crimson, large and double.

General MacArthur-Bright crimson, large.

General S. A. Janssen-Deep glowing carmine.

George Dickson-Velvety black crimson.

Gruss an Teplitz-Scarlet, shading to velvety crimson.

Jonkheer J. L. Mock-Deep pink, petals silvery rose.

Jubilee-Pure red, shading to crimson at base of petals.

Juliet-Petals outside gold, inside rich rosy red.

Kaiserin Augusta Victoria-Delicate creamy white.

Killarney-Deep shell pink, long pointed buds.

Killarney White-Pure white, long pointed buds.

La France-Silvery pink, fragrant.

Maman-Cochet Pink-Large, carmine-rose shaded salmon yellow. 


\section{HYBRID TEA ROSES-Continued}

Maman-Cochet White-Creamy white, fragrant.

Mme. Abel Chateney-Carmine rose shaded with salmon.

Mme. Caroline Testout-Salmon pink, large.

Mme. Ed. Herriott-Coral red, shaded red and bright scarlet.

Mrs. Aaron Ward-Coppery orange in open bud, pinkish fawn when full.

Mrs. Charles Russell-Rosy carmine.

Mrs. W. C. Miller-Bright pink with light shadings, splendid bloomer.

Ophelia-Salmon flesh shaded with rose.

Pharisaer-Rosy white, shaded salmon.

Radiance-Brilliant carmine-pink, with salmon-pink and yellow shadings.

Richmond-Pure red-scarlet.

Sunburst-Rich yellow, shaded coppery orange.

Willowmere-Very large, coral-red with deep yellow center.

\section{NEW ROSE INTRODUCTIONS}

$\$ 125$ each, $\$ 1100$ per 10.

Columbia-Beautiful rose-pink, perfectly formed blossoms.

Hadley-Brilliant deep velvety crimson, fragrant.

Los Angeles-Bright flame-pink, shaded with gold.

\section{POLYANTHA ROSES}

$\$ 1.00$ each, $\$ 850$ for $10, \$ 7500$ per 100 .

$\begin{array}{lll}\text { Baby Dorothy } & \text { Baby Rambler White } & \text { Jessie } \\ \text { Baby Rambler } & \text { Catherine Zeimet } & \text { Orleans }\end{array}$

\section{CLIMBING ROSES}

$\$ 100$ each, $\$ 850$ for $10, \$ 7500$ per 100 .

American Pillar (pink)

Baltimore Belle (pale blush)

Climbing American Beauty (pink)

Dr. Van Fleet (rich flesh pink)

Dorothy Perkins (double pink)

Dorothy Perkins Red (excelsa)
Dorothy Perkins White (white)

Hiawatha (beautiful single red)

Lady Gay (cherry pink)

Setigera (see Rosa, under Shrubs)

Silver Moon (silvery white)

Tausendschon (pink, large trusses)

HARDY RAMBLERS

$\$ 100$ each, $\$ 850$ for $10, \$ 7500$ per 100 .

Crimson Rambler

Excelsa

Pink Rambler
White Rambler

Philadelphia Rambler

\section{HYBRID SWEET BRIARS}

$\$ 100$ each.

Amy Robsart-Deep rose. Jeannie Deans-Scarlet crimson.

Anne of Geierstein-Dark crimson. Meg Merrilies-Crimson.

\section{ROSA RUGOSA HYBRIDS}

$\$ 100$ each, $\$ 900$ per 10 .

Blanche de Coubert

Conradi Ferdinand Meyer
Mme. Georges Bruant

Roseraie de l'Hay

\section{WICHURAIANA HYBRIDS}

$\$ 100$ each, \$9 00 per 10.

Gardenia-Bright yellow. 


\section{FRUIT TREES}

Each Per 10 Per 100

STANDARD APPLES

5 to $7 \mathrm{ft} .3 / 4$ in.................... $125 \quad 1150 \quad 10000$

We have the following varieties to offer this spring:

Baldwin
Ben Davis
Delicious
Early Strawberry
Fameuse
Golden Russett
Golden Sweet
Gravenstein
Grime's Golden
McIntosh Red
Northern Spy
Porter
Pumpkin Sweet
Red Astrachan
R. I. Greening
Rox. Russett

\author{
Smokehouse \\ Sweet Bough \\ Spitzenburg \\ Stark \\ Talman Sweet \\ Wagener \\ Wealthy \\ Yellow Belleflower
}

6 to $7 \mathrm{ft} .1$ to $1 \frac{1}{4} 4$ in. ............ $225 \quad 2000$
Varieties:
Delicious
Duchess
Fameuse
Gano

Hub. Nonesuch
King
Maiden's Blush
McIntosh Red
Newtown Pippin

Pound Sweet

R. I. Greening

Stayman's Winesap

Talman Sweet

We have the following trees to offer in the Bearing Age at prices ranging from $\$ 3.00$ to $\$ 5.00$.

\section{Early Harvest \\ English Russett \\ Fallawater \\ Fall Pippin \\ Golden Sweet}

Porter

R. I. Greening

Stark

Stayman's Winesap

Wagener

\begin{abstract}
Winter Banana
Wolfe River

Yellow Belleflower

Yellow Transparent

York Imperial
\end{abstract}

CRAB APPLES

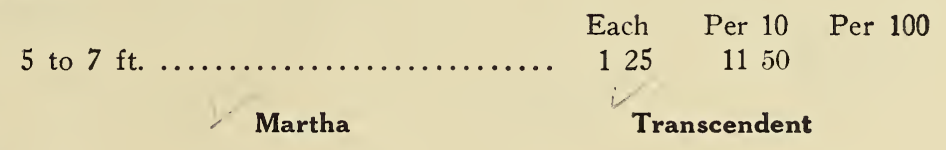

Hyslop

Martha

Transcendent

\section{DWARF APPLES}

2 and 3 yrs. ................ $150 \quad 1400$

Varieties:

Duchess
Early Harvest

Gravenstein

Red Astrachan
R. I. Greening Yellow Trans.

We have the following three varieties in heavier trees .............. $250 \quad 2250$ 


\section{STANDARD PEARS}

Viz.:

$$
\begin{array}{rr}
\text { Each } & \text { Per } 10 \\
150 & 1250
\end{array}
$$

Bartlett

Beurre Bosc

B. d'Anjou

Clapp's Favorite
Duchess

Flemish Beauty

Lawrence

Louise Bonne

\section{Sheldon}

Seckel

Worden Seckel

Winter Nellis

\section{CHERRIES}

First class 11-16 in. and up.

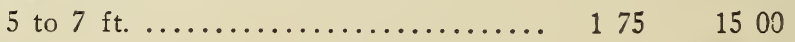

Varieties:

Black Tartarian

Governor Wood

Montmorency

Napoleon Big.
Windsor

Yellow Spanish

\section{PEACHES}

9-16 in. and up.

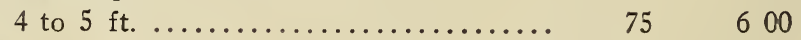

Varieties:

Belle of Georgia

Champion

Carman

Crawford's Early

PLUMS First Grade

Elberta

Crawford's Late

Fitzgerald

Greensboro

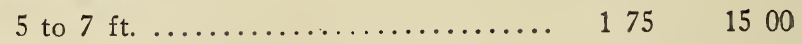

\section{Foster}

Stump

Old Mixom

J. H. Hale

Varieties:
Abundance
Lombard
Bradshaw
October Purple
Burbank
Red June
Damson
Reine Claude

\section{Satsuma \\ Wickson \\ Yellow Egg}

\section{QUINCES}

4 to $5 \mathrm{ft} . \ldots \ldots \ldots \ldots \ldots \ldots \ldots \ldots \ldots \ldots \ldots \ldots \ldots$

Varieties:

Champion

Meech's Prolific Rea's Mammoth
Orange

\section{SMALL FRUITS}

\section{GRAPES}

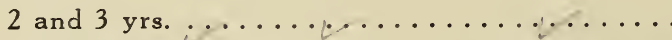

Blue-Black: 'Concord, Campbell's Early, Moore's Early, Worden.

Red: Brighton, Catawba, Delaware, Salem.

White: Green Mountain, Moore's Diamond, Niagara. 
RASPBERRIES-Transplants. 1 to 25 plants $10 \mathrm{c}$. each, 25 to 250 8c., and 250 and up $7 \mathrm{c}$.

Varieties:

Columbian

Cuthbert

BLACKBERRIES-Transplants.

\section{Varieties:}

Agawam

Blowers
LGregg

Marlboro

- Golden Queen
Herbert

St. Regis

Rathbun

Snyder
Early Harvest

Eldorado

Erie

Each Per 10 Per 100

ASPARAGUS -2 yrs. $. \ldots \ldots \ldots \ldots \ldots \ldots \ldots \ldots \ldots \ldots \ldots . \ldots \ldots$

Conover's, Giant Argenteuil, Palmetto.

RHUBARB-Myatt's Linnaeus, Victoria.

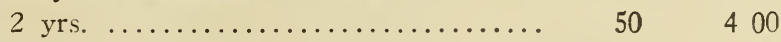

\section{STRAWBERRIES}

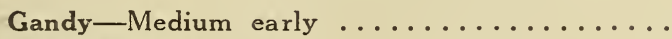

Per 100 Per 1000

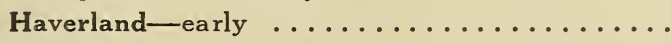

$150 \quad 1200$

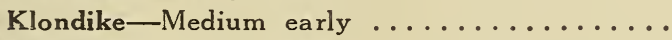

Marshall-Medium late .............

$150 \quad 1200$

Mitchell's Early-Early . . . . . . . . . . . .

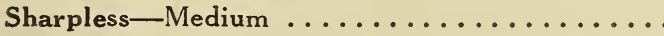

$150 \quad 1200$

$200 \quad 1500$

$150 \quad 1200$

$150 \quad 1200$

Peerless

Everbearing varieties ..

$250 \quad 2000$

Progressive

Superb

\section{CURRANTS and GOOSEBERRIES}

On account of the "White Pine Blister-rust" which spreads from these plants to White Pines and other five-needled Pines, we have discontinued growing and selling Currants and Cooseberries.

\section{See CONDITIONS OF SALE on page 2.}



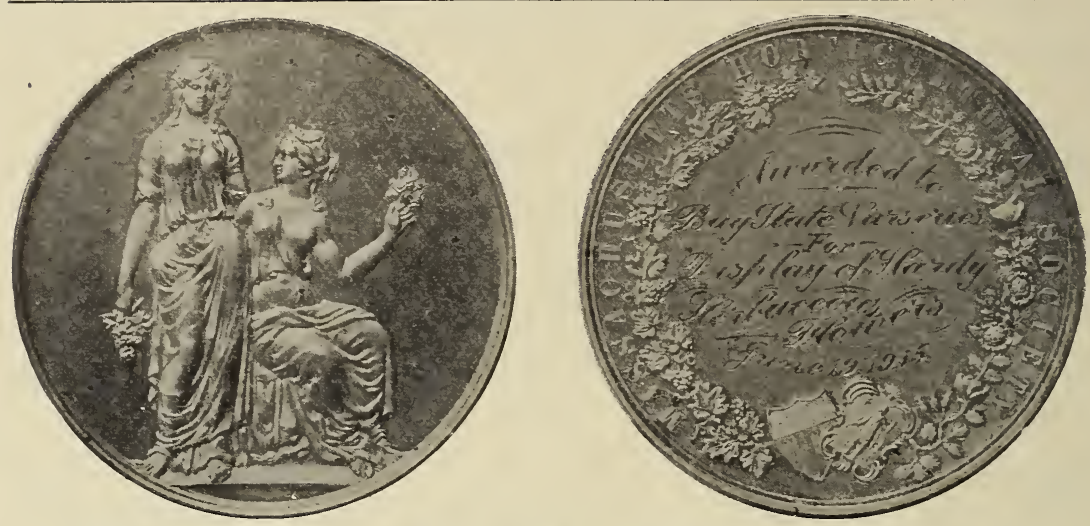

Silver Medal awarded us by the Massachusetts Horticultural Society for the best display of Herbaceous Flowers.

\section{Herbaceous Department}

On account of the increasing popularity and demand for Herbaceous Perennials, our acreage nas been extended from year to year, so that now this department alone covers about eighteen acres, with several greenhouses especially designed for propagating this class of plants. We are adding new and choice plants to our collection each year.

About all the plants we grow are strong field-grown; the only exceptions being a few species which transplant better by being grown in pots, also some of the choice new varieties.

\section{HARDY PERENNIALS, FERNS AND GRASSES}

Full descriptions will be found in our General Catalogue.

Varieties marked with a star $(\star)$ are particularly adapted for the rockgarden.

See CONDITIONS OF SALE on page 2.

Remember that 25 perennials of one kind are entitled to the hundred rates whenever the hundred rate is given.

Each Per 10 Per 100

ACANTHUS mollis-Bear's Breech ........ $35 \quad 300$

ACHILLEA-Milfoil or Yarrow

\begin{tabular}{|c|c|c|c|}
\hline Aegyptica $\ldots \ldots \ldots \ldots \ldots \ldots \ldots \ldots \ldots$ & 30 & 240 & \\
\hline Eupatorium $\ldots \ldots \ldots \ldots \ldots \ldots \ldots \ldots$ & 25 & 220 & \\
\hline Millefolium $\ldots \ldots \ldots \ldots \ldots \ldots \ldots$ & 25 & 220 & 1500 \\
\hline var. roseum-Rosy Milfoil $\ldots \ldots \ldots \ldots \ldots \ldots$ & 25 & 180 & 1200 \\
\hline Ptarmica fl. pl.—"The Pearl" . . . . . . . . & 25 & 220 & 1500 \\
\hline "Perry's" White .................. & 30 & 240 & 1800 \\
\hline tomentosa $\ldots \ldots \ldots \ldots \ldots \ldots \ldots \ldots \ldots$ & 25 & 200 & 1400 \\
\hline
\end{tabular}


ACONITUM-Monkshood or Helmet Flower

autumnale $\ldots \ldots \ldots \ldots \ldots \ldots \ldots \ldots \ldots$

barbatum $\ldots \ldots \ldots \ldots \ldots \ldots \ldots \ldots \ldots \ldots$

cammarum Stoerkianum $\ldots \ldots \ldots \ldots \ldots \ldots$

Fischerii

longigantatum

Napellus

var. bicolor

var. Sparks

pulcheriana

tennisectum

uncinatum

Wilsonii, very scarce

ACORUS Calamus-Sweet Flag

var. variegata

ACTAEA spicata

AEGOPODIUM podograria variegatum-Bishop's

Weed

AGROSTEMMA-Mullein Pink

coronaria

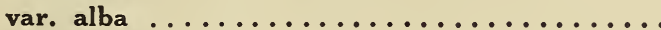

Flos. Jovis

$\star$ AJUGA - genevensis

treptans rubra

ALTHAEA rosea-Hollyhock

Double varieties-Pink, red, white, yellow .....

Single varieties-Pink, red white, yellow ......

Alleghany

ALYSSUM-Madwort

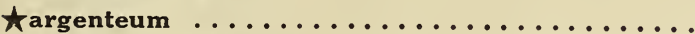

$\star$ saxatile compactum

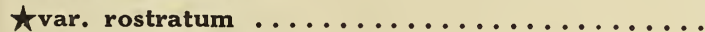

AMSONIA salicifolia

Tabernaemontana

ANCHUSA italica-Alkanet

var. Dropmore $\ldots \ldots \ldots \ldots \ldots \ldots \ldots \ldots \ldots \ldots$

var. opal

sempervirens

ANEMONE Japonica rubra-Wind Flower

var. alba

var. Lady Ardilaun
Each

30

1800

1800 
ANEMONE - continued

$\begin{array}{rrr}\text { Each } & \text { Per } 10 & \text { Per } 100 \\ 30 & 240 & 1800 \\ 25 & 220 & 1500 \\ 25 & 220 & 1500 \\ 25 & 220 & 1500 \\ 30 & 240 & 1800 \\ 35 & 300 & \\ 30 & 240 & \end{array}$

var. Prince Heinrich

1800

ANTHEMIS Kelwayi-Chamomile ......... 30

AQUILEGIA-Columbine

$\star$ caerulea-Rocky Mountain Columbine ...... 30

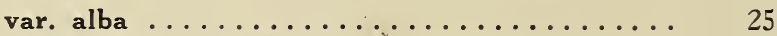

Californica hybrida ................ 25

$\star$ canadensis

240

1800

chrysantha

220

1500

$\star f$

30

2.40

1800

flabellata nana

220

1500

var. nana alba

220

1500

nivea grandiflora

220

1500

Skinneri

220

1500

truncata

220

1500

vulgaris

220

1500

var. alba

220

$150 \mathrm{C}$

var. flore plena

220

1500

var. flore plena alba

220

1500

ARABIS albida

240

1800

Łalpina-Rock Cress ................ 25

$220 \quad 1500$

$\star$ ARENERIA balearica-Sandwort ......... 30

$\star$ montana

240

1800

$30 \quad 240$

ARMERIA $\star$ cephalotes rubra-Sea Pink....... 25

220

1500

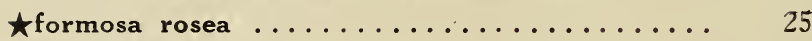

220

1500

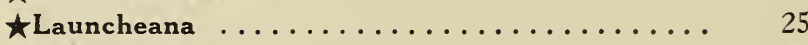

$\star$ var. robusta

220

15004

$\star$ maritima

220

1500

220

$150 \mathrm{~s}$

$\star$ var. alba

240

1800

$\star$ ARRHENATHERUM bulbosum variegata

240

ARTEMISIA-Wormwood

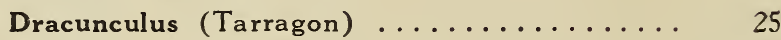

$\star$ frigida

gnaphaloides

250

1800

lactiflora

220

1500

pontica

300

Stellariana-Old Woman 
ASCELEPIAS incarnata-Milkweed ........ tuberosa $\ldots \ldots \ldots \ldots \ldots \ldots \ldots \ldots \ldots \ldots \ldots$

ASTER

Varieties-(See General Catolog for descriptions) acris

$\star$ alpinus

$\star$ var. albus

var. altaicus

var. rubrus

Amellus var. bessarabicus

Combe Fishacre

Dumosus

ericoides

Esma
longifolia formo
Grace
Isabel
John Wood
Lady Trevellyn
laevis
var. floribunda
Madonna
multiflorus

ASTER-Choice New Varieties

Beauty of Colwall-Double lavender ........

Beauty of Ronsdorf-Lilac Pink ...........

Climax-Light lavender-blue ..........

Feltham-Blue with yellow center.........

Japanese-Double white .............

Novae-angliae alba-Pure white .........

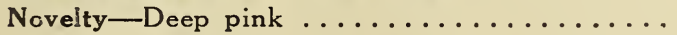

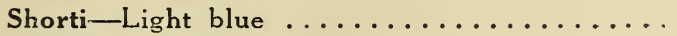

Sibericus-Blue, foliage, bright crimson ......

Spectabilis var. Nenco-Deep lavender .......

St. Egwyn-Bright pink .............

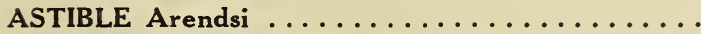

Varieties,Ceres-Rosy Lilac; Gerbe d'Argent-(pure white; Gloria, etc.)

pure white; Gloria-deep pink; Juno-violet rose; M. Ammick; Moerheimii-creamy white; Panache-light pink; Pyramidal-pure white; Rose Pearl-shell pink; Salland-red; Vestalilac rose.

white.

chinensis $\ldots \ldots \ldots \ldots \ldots \ldots \ldots \ldots$

compacta multiflora $\ldots \ldots \ldots \ldots \ldots \ldots \ldots$

Davidii

Gladstone $\ldots \ldots \ldots \ldots \ldots \ldots \ldots \ldots \ldots$

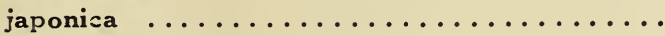

Peach Blossom

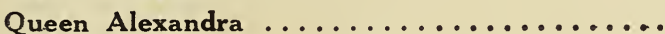

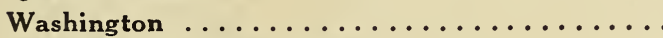

WashRington

Łdeltoides $\ldots \ldots \ldots \ldots \ldots \ldots \ldots \ldots \ldots \ldots$

$\star$ Łraeca $\ldots \ldots \ldots \ldots \ldots \ldots \ldots \ldots \ldots \ldots \ldots$

purpurea $\ldots \ldots \ldots \ldots \ldots \ldots \ldots \ldots \ldots$

BAPTISIA australis (False Indigo) $\ldots \ldots \ldots \ldots$

tinctoria

BELLIS perennis (English Daisy) $\ldots \ldots \ldots \ldots$

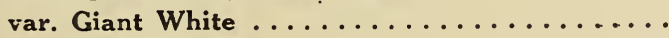

var. Giant Pink

$\begin{array}{rrr}\text { Each } & \text { Per } 10 & \text { Per } 100 \\ 30 & 240 & 1800 \\ 35 & 300 & 2400 \\ 25 & 220 & 1500\end{array}$

novae-angliae

var. roseus

novi-belgii

ptarmicoides

pulcherrima

Snowllatre

Tartaricus

Top Sawyer

T. S. Ware

Each Per 10 Per 100

$30 \quad 240 \quad 1800$

$\begin{array}{llll}30 & 240 \quad 1800\end{array}$

$30 \quad 240 \quad 1800$

$30 \quad 240 \quad 1800$

$30 \quad 240 \quad 1800$

$30 \quad 240 \quad 1800$

$30 \quad 240 \quad 1800$

$\begin{array}{lll}30 & 240 \quad 1800\end{array}$

$35 \quad 300$

$30 \quad 240 \quad 1800$ :

$30 \quad 240 \quad 1800$

$50 \quad 350$

25 
BETONICA See STACHYS

BOCCONIA cordata (Plume Poppy) ........ 30

BOLTONIA asteroides (False Chamomile) .....

latisquama $\ldots \ldots \ldots \ldots \ldots \ldots \ldots \ldots \ldots$

var. nana $\ldots \ldots \ldots \ldots \ldots \ldots \ldots \ldots \ldots$

laevigata

Each

Per 10 Per 100

BUPHTHALMUM salicifolium-Ox-eye ...... 30

CALIMERIS incisa $\ldots \ldots \ldots \ldots \ldots \ldots \ldots . \ldots \ldots$

$240 \quad 1800$

25

220

1500

25

220

1500

30

240

1800

25

220

1500

CALLIRHOE involucrata .............. 35

240

CALTHA palustris (Marsh Marigold)

30

240

1800

CAMPANULA-Bellflower

$\star$ carpatica (Carpathian Hare Bell) .........

$\star$ var. alba

glomerata

grandis

lactiflora

latifolia

var. macrantha .................... 30

1800

media (Pink, Blue, White and Mixed) ........ var. calycanthema (Pink, Blue, White and Mixed) .................... 30 persicaefolia grandiflora $\ldots \ldots \ldots \ldots \ldots \ldots \ldots$ var. alba $\ldots \ldots \ldots \ldots \ldots \ldots \ldots \ldots \ldots \ldots \ldots$

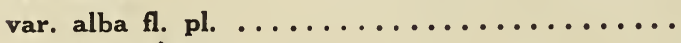

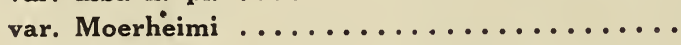
pulcherrima.$\ldots \ldots \ldots \ldots \ldots \ldots \ldots \ldots \ldots$ pyramidalis (The Chimney Bell Flower) ......

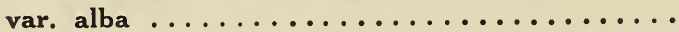
$\star$ rotundifolia (Blue Bells of Scotland or Hare Bell) trachelium (Coventry Bells) ............

CENTAUREA dealbata (Century) ..........

var. rosea $\ldots \ldots \ldots \ldots \ldots \ldots \ldots \ldots \ldots \ldots$

ruthenica 
CHELONE glabra

$\begin{array}{rrr}\text { Each } & \text { Per } 10 & \text { Per } 100 \\ 25 & 220 & 1500 \\ 25 & 220 & 1500\end{array}$

Lyonii

CHRYSANTHEMUM Hardy Pompom. Eight colors, including pink, white, yellow, etc. .....

Named Varieties (See General Catalog for description)

$30 \quad 240 \quad 1800$

Aberdeen-Bright maroon

Agrippina-Large double pink

A. Neilson-Wine color, silvery reverse petals

Autumn Queen-Rose pink

Baby-Button type, yellow

Boston-Golden bronze

Brutus-Old gold

Crimson Pride-Deep crimson, yellow backed

Fremy-Terra-cotta

Golden Pheasant-Orange yellow

James Boone-Large white

Johnson's Favorite-Double rosypink

Julia Lagravere-Large velvety-maroon

Roi de Precoces-Cactus variety, deep crimson petals backed with cream

Ruby Queen-Dark ruby-red

Susquehanna-Single golden yellow Viola-Violet pink

latifolium 25

leucanthemum hybridum (Shasta Daisy)...... 25

220

1500

leucanthemum plenum

220

1500

maximum

40

var. Alaska

var. Articum

360

2800

var. King Edward

var. Robinsonii

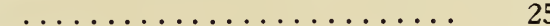

220

1500

var. The Speaker $(\mathrm{New}) \ldots \ldots \ldots \ldots \ldots \ldots . \ldots . \ldots$

220

1500

var. Triumph $\ldots \ldots \ldots \ldots \ldots \ldots \ldots \ldots \ldots \ldots$

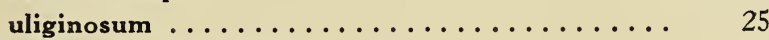

240

1800

220

1500

CIMICIFUGA cordifolia

220

1500

240

racemosa

2000

simplex

350

CLEMATIS davidiana

recta

CONOCLINIUM coelestium (Mist flower)...... 30

CONVALLARIA (Lily of the Valley) clumps ....

$\star$ COPTIS trifolia

COREOPSIS delphinifolia (Tick Seed)

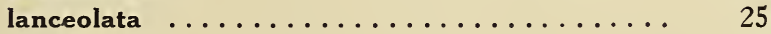

$220 \quad 1500$

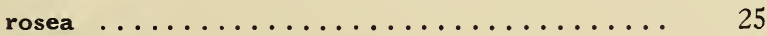

$220 \quad 1500$

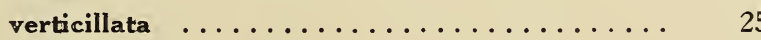

$220 \quad 1500$

$\star$ CORONILLA varia

$30 \quad 240$


DELPHINIUM (Hardy Larkspur)

Each

Per 10

Per 100

Named varieties (Double) (See Catalogue)....

90

750

Gold Medal hybrids

240

1800

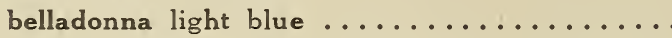

300

2000

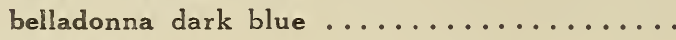

300

2000

chinensis

240

1800

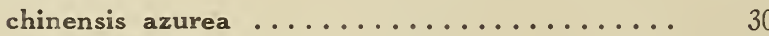

240

1800

var. alba

240

1800

elatum

240

1800

formosum

240

1800

var. coelestinum

240

DIANTHUS atro-rubens

240

barbatus (Sweet William) Colors: Pink, Red

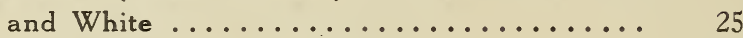

barbatus var. Newport Pink ........... 30

220

1800

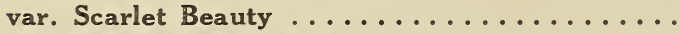

chinensis var. Heddewigi (Many colors) ......

$\star$ deltoides (Maiden Pink) ............ 30

plumarius (Scotch or Garden Pink) ........

p. var. semperflorens

HARDY GARDEN PINKS Abbotsford-Crimson. .

$\star$ Carmen-light pink, fragrant ...........

Her Majesty-large pure white .........

Homer-dark red

Lord Lyons-pink ................

Louisa M. Alcott-large, deep pink .........

Mrs. Sinkins-large white, fragrant ........

Souvenir de Sale-soft pink ...........

White Reserve-ever blooming ..........

HARDY CARNATIONS

Grenardin's Scarlet ................ 30

Grenardin's White ................. 30

240

DICENTRA eximea

formosa

DIGITALIS (Foxglove)

ambigua or grandiflora (Yellow Foxglove) ....

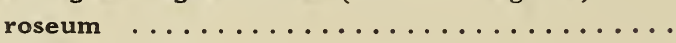

gloxiniaeflora

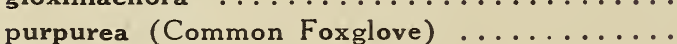

purpurea

220

1500 
Each

Per 10

Per 100

EPILOBIUM a ugustifolium ............. 30

240

1800

EPIMEDIUM $\star$ alpinum var. rubrum (Barren Wort)

1800

$\star$ macranthum var. niveum . . . . . . . . .

Łvar. sulphureum ............... 30

ERIANTHUS Ravennae (Ravenna Grass) .......

ERIGERON aurantiacus (Flea-bane) .........

Quakeress (New) ................. 30

ERYNGIUM alpinum (Sea Holly) ..........

var. variegata $\ldots \ldots \ldots \ldots \ldots \ldots \ldots \ldots \ldots$

EUPATORIUM ageratoides (Through-Wort) ....

Frazeri

EUPHORBIA corrollata (Flowering Spurge) ....

$\star$ ASPIDIUM acrostichoides (Christmas Fern).

A. Goldianum.

$\star$ A. marginale.
A. spinulosum.

ASPLENIUM ebeneum.

$\star$ A. Filix-foemina (Lady Fern).

CAMPTOSORUS rhizophyllus (Walking Leaf).

$\star$ CRYTOGRAMMA crispa acrostichoides.

$\star$ DICKSONIA punctilobula.

ONOCLEA sensibilis (Sensitive Fern).

O. Struthiopteris.

OSMUNDA cinnamomea (Cinnamon Fern).

O. regalis (Flowering Fern).

^WOODSIA lvensis (Rusty Woodsia).

WOODWARDIA angustfolia (Chain Fern).

$\star$ FESTUCA glauca (Blue Fescue Grass) .......

FUNKIA caerulea (Plantain Lily) ..........

var. marginata

var. Thos. Hogg . . . . . . . . . . . . . . . . . 
GAILLARDIA artista (Blanket Flower) ....... 25

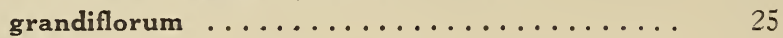

maxima

GALEGA bicolor Hartlandi (Goat's Rue)

Heldrichii

officinalis

$\star$ GERANIUM sanguineum (Crane's Bill) ......

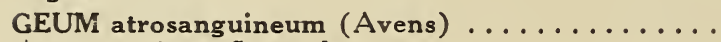

\section{America \\ Augusta}

Brenchleyensis

Halley

GLYCERIA speciosum (Ribbon Grass) ........

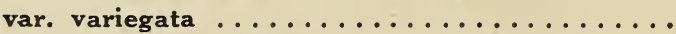

GYPSOPHILA acutifolia

Independence

Mrs. Francis King

Panama

1000

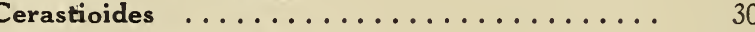

HELENIUM autumnale (Sneeze Wort) ........

var. Riverton Beauty ...............

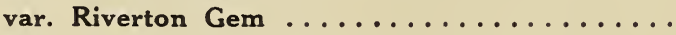

var. rubrum

var. striatum

Hoopesii

HELIANTHEMUM \angustifolium (Sun Rose)...

Łhyssopifolium $\ldots \ldots \ldots \ldots \ldots \ldots \ldots$

$\star$ perfoliatum roseum

Maximiliana

maximus

mollis

multiflorus plenus var. Meteor 
HELIOPSIS laevis (Ox-eye)

Each

Pitcheriana

var. semi-plena

scabra major

$\star$ HELXINE Solierli

HEMEROCALLIS aurantiaca major (Day Lily) ..

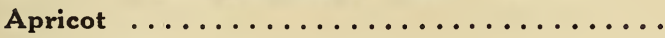

Dumortieri $\ldots \ldots \ldots \ldots \ldots \ldots \ldots \ldots \ldots$

flava

florum

fulva

Gold Dust

gracilis

Kwanso fl. pl.

Orange Man

pallens

Sieboldi

Thunbergiana

HEPATICA acutiloba

triloba

r

$\star$ tvar. alba

$\star$ HEUCHERA sanguinea (Alum Root)

var. alba

tvar. americana

var, brizoides

$\star$ var. gracilis rosea

var. Grenade scarlet

HIERACIUM Aurantiacum (Hawk-weed)

HIBISCUS militaris (Mallow) . .........................

Marvel Mallows Red, White, Pink and Mixed. .

Moscheutos (Swamp Rose Mallow) .........

var. "Crimson Eye"

$\star$ HUTCHINSIA alpina

$\star$ HYSSOPUS officinalis (Hyssop)

HOLLYHOCKS (See Althaea rosea)

IBERIS sempervirens (Evergreen Candytuft) .... sempervirens fl. pl. .............. var. Snowflake

corifolia

Tenoreana

INCARVILLEA Delavayi grandiflora

INULA glandulosa salicana
Per 10

Per 100

$30 \quad 240 \quad 1800$

$30 \quad 240 \quad 1800$

$30 \quad 240$

30

240

1800

35

35

25

30

30

30

25

30

25

30

30

50

30

30

30

30

30

30

30

30

30

30

30

35

30

25

35

30

30

45

30

300

2000

330

2000

220

1500

240

1800

240

240

220

240

220

240

240

1800

1500

1800

1500

1800

1800

$240 \quad 1800$

240

1800

$240 \quad 1800$

$240 \quad 1800$

$240 \quad 1800$

$240 \quad 1800$

$240 \quad 1800$

$240 \quad 1800$

$240 \quad 1800$

$240 \quad 1800$

$240 \quad 1800$

$300 \quad 2000$

$240 \quad 1800$

$220 \quad 1500$

3 on 2800

$240 \quad 1800$

$240 \quad 1800$

360

$240 \quad 1800$

30

240

1800

$30 \quad 240$

$30 \quad 240$

1800

$30 \quad 240 \quad 1800$

$30 \quad 240 \quad 1800$

$35 \quad 300$

$35 \quad 300$

$30 \quad 240$

1800

30 


\section{IRIS}

We have upwards of one hundred and fifty varieties in our collection, including all classes in both named varieties and separate colors. For description see our Catalogue.

$\star$ IRIS Alpine-A new race of early flowering Iris, March to May, 6 to 9 inches

Named Varieties .................. $40 \quad 400 \quad 3200$

Alpine. Mixed Colors ............... $40 \quad 350 \quad 2400$

$\begin{array}{lllll}\text { Adelaide } & \text { Beatrice } & \text { Clothilde } & \text { Goethe } & \text { Milton } \\ \text { Alida } & \text { Berlioz } & \text { Delicata } & \text { Grandee } & \text { Othello } \\ \text { Aureole } & \text { Charmer } & \text { Evelyn } & \text { Meteor } & \end{array}$

Germanica Named Varieties .

Admiral Togo

Garrick

Atroviolacea (Purple)

Augustina

Brooklyn

Canary Bird

Charlotte Patti

Charles Dickens

Comte de St. Clair

Darius

Flavescens

Florentina Alba

Florentina Blue

pallida dalmatica

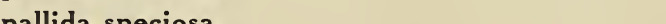

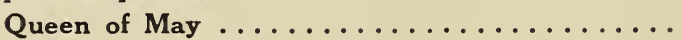

Kaempferi Named Varieties

Kaempferi Mixed Colors

Alba plena

Alida

A. L. Sherwood

Babylon

Beth Hallock

Blue Bird

Blue Danube

Commodore Perry

Eclair
Gen. Grant

Gold Bound

Hector

Herant

Hokanum

Horatius

Johan De Witt

L'Africaine

Leopold

Lizzie

Lord Macaulay

30

220

1500

Madame Chereau

Mrs. Charles Darwin

Oroya

Pauline

Pecutum

Purple King

Rebecca

Sir Robert Peel

Striata

Ulysses

Violette

William III

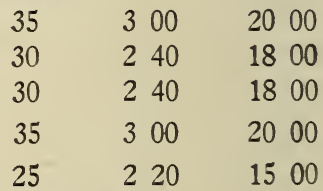

Painted Lady

Paragon

Prof. Georgeson

Purple Emperor

Pyramid

Turban

Venus

William Tell

\section{MISCELLANEOUS IRIS}

$\star$ cristata .................... 30

pseudacorus (Water Flag Yellow, May and June)

$\star$ pumila atroviolacea (Maroon-red) ..........

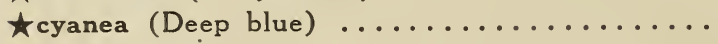


MISCELLANEOUS IRIS - continued

Each

var. alba

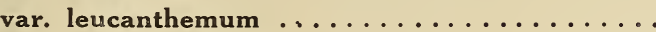

var, orientalis Blue (Yale Color) .........

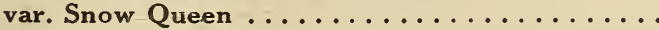

verna

LATHYRUS latifolius (Everlasting Pea) var. albus

var. Pink Pearl

LAVENDULA Spicata vera (Lavender)

LIATRIS odorotissima (Blazing Star) pyscnostachya spicata

\section{LILIUM (Lily)}

auratum (Gold Band) ................. 40

canadense (Wild or Canada Lily) ......... 30

carolinianum

elegans (Deep Maroon)

var. umbellatum (Orange Red) ...........

giganteum (Delicate creamy white) $\ldots . \ldots \ldots$

Hansoni

longiflorum (White)

philadelphicum

regale

speciosum album

var. rubrum

superbum (Reddish orange)

tigrinum splendens (Tiger Lily)

tigrinum fl. pl. (Double Tiger Lily)

LINARIA alba

LINUM perenne-Flax

LOBELIA Cardinalis-Cardinal Flower

syphilitica

var. alba

LUPINUS polyphyllus-Lupin

var. albus

var. Moerheimi

var. roseum

LYCHNIS $\star$ alpina

var. chalcedonica

var. alba

var. rubra plena
25

25

25

25

30

30

30

30

30

30

30

30

30

35

35

35

35

40

35

30

75

40

40

30
Per 10

Per 100

$\begin{array}{lllll}2 & 20 & & 15 & 00 \\ 2 & 20 & & 15 & 00 \\ 2 & 20 & & 15 & 00 \\ 2 & 20 & & 15 & 00 \\ 2 & 40 & & 18 & 00 \\ 2 & 40 & & 18 & 30 \\ 2 & 40 & & & \\ 2 & 40 & & 18 & 00\end{array}$

240

240

1800

$240 \quad 1800$

$240 \quad 1800$

$240 \quad 1800$

350

2500

$240 \quad 1800$

$300 \quad 2000$

300

300

300

2000

350

3000

300

240

700

2000

6000

350

2500

350

240

2500

1800

300

2700

300

2700

240

240

1800

240

1800

$220 \quad 1500$

$220 \quad 1500$

$240 \quad 1800$

$240 \quad 1800$

$240 \quad 1800$

$240 \quad 1800$

240

240

1800

240

1800

250

1800 
LYCHNIS - continued

Each

coronaria

Haageana

viscaria splendens

var. flora plena

LYSIMACHIA nummularia-Moneywort

LYTHRUM alatum

Perry's Variety (New)

roseum superbum

MALVA alcea-Mallow

moschata

var. alba

MEGASEA (See Saxafraga)

MELISSA officinalis .............. 30

MENTHA $\star$ requieni (creeping) $\ldots \ldots \ldots \ldots \ldots \quad 30$

spicata or virides (Spearmint) .......... 30

MERTENSIA Virginica ............... 25

MITCHELLA repens (Partridge Berry) ....... 30

MONARDA Cambridge Scarlet ........... 30

didyma-Bee Balm .................. 30

fistulosa (Bergamot) $\ldots \ldots \ldots \ldots \ldots \ldots \ldots$

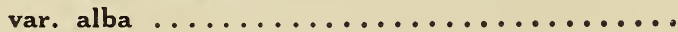

violacea $\ldots \ldots \ldots \ldots \ldots \ldots \ldots \ldots \ldots \ldots \ldots$

MYOSOTIS dissitiflora (Forget-Me-Not) .......

palustris semperflorens $\ldots \ldots \ldots$

$\star$ NEPETA cataria (Catnip) ............

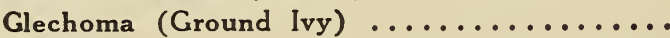

Mussini

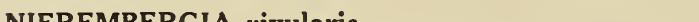

OENOTHERA caespitosa (Evening Primrose) ....

30

30

30

30

25

Frazerii

fruticosa major

var. Youngi

$\star$ repens

speciosa

$\star$ OPUNTIA missouriensis

$\star$ vulgaris

$\star$ ORIGANUM bulgare (Wild Marjoram).......

Marjorana

$\star$ PACHYSANDRA terminalis from 3 in. pots

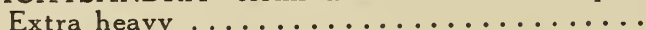

from $2 \frac{1}{2}$ in. pots

30

Per 10

Per 100

240

1800

240

1800

240

1800

240

1800

220

15 on

240

1800

240

180 )

240

1800

240

1800

240

180 0

240

1800

240

1800

240

240

1800

220

1500

240

1800

240

1800

240

1800

240

1800

240

1800

240

1800

240

220

1500

240

1800

240

1800

240

1800

240

240

240

1800

240

1800

240

1800

240

1800

1800

240

1800

300

240

1800 


\section{PAEONIAS}

Heretofore we have grown paeonias in scores of sorts. Now we have disposed of all but a fow choice varieties-all that the average garden requires, viz. :

Alexander Dumas, early, light violet rose .....

$\begin{array}{rrr}\text { Each } & \text { Per } 10 & \text { Per } 100 \\ 75 & 600 & \\ 75 & 600 & \\ 75 & 500 & \\ & & \\ 75 & 600 & \\ 90 & 800 \\ 75 & 600 & \\ 125 & 1200\end{array}$

$90 \quad 800$

Francois Ortegal, semi-double, large purplishcrimson with brilliant golden yellow antlers..

General Bertrand, early, bright pink ........

Lady Bramwell, medium silvery pink ........

L'Illustration, rose ................

La Sublime, crimson, fragrant ..........

Louis Van Houtte, late, large dark variety, pur-

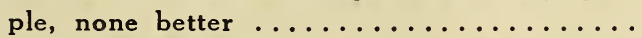

Mme. de Verneville, very large and fragrant, pure white with center tinged with carmine..

Queen Victoria, medium, creamy-white, with crimson spots ................

Rosea Plena Superba, delicate pink and salmon.

Double Pink, Double Red and Double White ...

PAPAVER orientale-Oriental Poppy ........

orientale hybrids, varieties ............

$\begin{array}{ll}\text { Goliath } & \text { Mrs. Perry } \\ \text { Loreley } & \text { Oriflame } \\ \text { Mahony } & \text { Oriental King }\end{array}$

^nudicaule - lceland Poppy colors, Orange, White

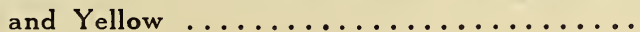

PARDANTHUS chinensis $\ldots \ldots \ldots \ldots \ldots \ldots$

PENSTEMON-Beard Tongue

acuminatus $\ldots \ldots \ldots \ldots \ldots \ldots \ldots \ldots$

barbatus Torreyii $\ldots \ldots \ldots \ldots \ldots \ldots \ldots$

diffusus $\ldots \ldots \ldots \ldots \ldots \ldots \ldots \ldots \ldots \ldots$

digitalis $\ldots \ldots \ldots \ldots \ldots \ldots \ldots \ldots \ldots \ldots$

heterophyllus $\ldots \ldots \ldots \ldots \ldots \ldots \ldots \ldots \ldots$

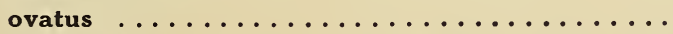

tubiflorus $\ldots \ldots \ldots \ldots \ldots \ldots \ldots \ldots \ldots$

PHALARIS spectabilis arundinacea Ribbon Grass.

var. variegata

$75 \quad 500$

$75 \quad 600$

$75 \quad 600$

$75 \quad 600$

$75 \quad 500$

$90 \quad 800$

$90 \quad 800$

$75 \quad 600$

$60 \quad 500$

$50 \quad 400$

$30 \quad 240$

$30 \quad 240$

1800

Queen Alexandra

Royal Scarlet

Salmon Queen

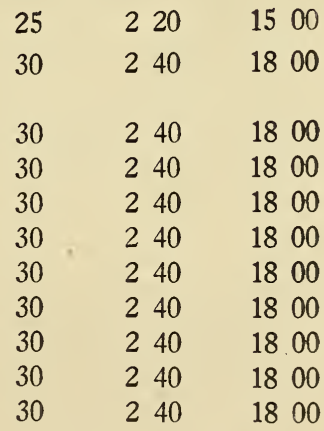




\section{PHLOX}

Our collection of Phlox includes the finest sorts to be found in this country PHLOX paniculata syn. decussata: Named

Varieties ................... $30 \quad 240 \quad 1800$

Annie Cook. Flesh pink.

Astrild. Dense trusses of medium sized flowers of brilliant cochineal carmine, shaded deeper towards center.

B. Comte. Dark red.

Baron van. Dedem. Blood-red.

Boule de Feu. Cherry-red.

Bridesmaid. White, rose center.

Coquelicot. Orange scarlet.

Crepuscule.

Dora Umgella. White, lilac-pink center.

Eclaireur. Carmine, salmon center.

Embarasement. Bright orange-scarlet.

Epopee. Reddish violet, bright cen ter.

Etta's Choice. Pure white.

Eugene Danzanvilliers. Lilac-blue, white center.

Europa. Snow white, carmine center.

F. G. Von Lassburg. Pure white.

Frau Anthony Buckner. The best white.

General Chanzy. Scarlet-pink, tinted salmon.

Glow. Scarlet.

Goliath. Red.

Grideur. Ground color, a soft mauve rose, heavily suffused and overlaid with a lively deep shade of cerise.

Gruppenkoenogin. Flesh-colored rose, with carmine eye.

Hector. Fine pink.

Independence. Pure white.

Japonaise. Delicate rose, white center.

Jeanne d'Arc. Pure white.

Le Pole du Nord. White crimson center.

Le Mahdi Metalic violet-blue.

L'Esperance. Light, lavender-pink, white center.

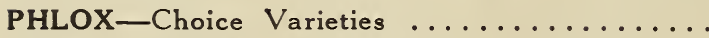

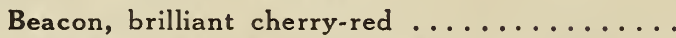

Elizabeth Campbell, bright salmon pink, dark red eye. Light grade in 2 in. pots.. ........

Siebold, bright scarlet, one of the best reds ....

Tapis de Blanc, (dwarf), very large, pure white
Each Per 10 Per 100

$30 \quad 240 \quad 1800$

L'Evenement. Delicate pink, tinted, almon.

Le Soleil. Brilliant china-rose, rose center.

Louise Abemma. Pure white.

Mme. Meuret. Flame color, carmine center.

Mme. Paul Dutrie. Soft pink, suffused with white.

Mme. P. Langier. Bright red, vermillion center.

Michael Buckner. Dark purple.

Mrs. E. E. Jenkins. Pure white, very large triss.

Ornament. Bright pink.

Pantheon. Brilliant rose, very effective.

Peach Blow. Delicate pink, rose center.

Pluto. Deep Fuchsia-red.

Prof. Schliemann. Bright red, crimson eye.

Prof. Vierschow. Brilliant carmine overlaid with orange-scarlet.

Queen. Pure white; late.

Richard Wallace. Pure White, violet-rose center.

Riverton Jewel. Lovely shade of mauve-rose with brilliant carmine-red eye.

Rosenberg. Bright reddish-violet, with blood-red eye; large truss.

R. B. Struthers. Bright, pinkish salmon, crimson eye.

Rynstrom. Bright carmine rose.

Saison Lierval. White, light pink center.

Thor. Lively shade of deep salmonpink, suffused and overlaid with a scarlet glow; analine red eye.

W. C. Egan. Very large flowers of delicate lilac with large bright solferino eye. The color effect as a whole is a pleasing shade of soft pink.

Widar. Bright reddish violet with large white center.

Each Per 10 . Per 100

$35 \quad 300$

$35 \quad 300$

$30 \quad 250$ 


\section{Dwarf or Creeping Phlox}

$\star$ PHLOX amoena................ 30

Each

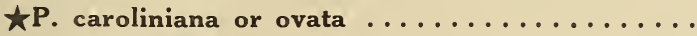

$\star P$. divaricata $\ldots \ldots \ldots \ldots \ldots \ldots \ldots \ldots$

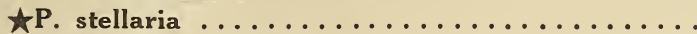

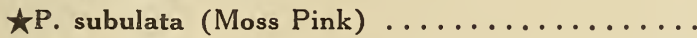

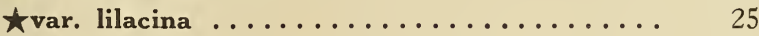

$\star$ tvar. Nelsoni ................... 25

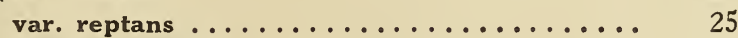

var. The Bride

PHLOX suffruticosa-Miss Lingard

Indian Chief $\ldots \ldots \ldots \ldots$

\section{Purple Emperor}

PHYSALIS Franchetti .................

PHYSOSTEGIA speciosa (False Dragon's Head) ..

PINKS. Hardy Garden (See Dianthus)

PLATYCODON grandiflora (Chinese Bell Flower)

Richardsonii

POLYGONATUM giganteum (Solomon's Seal) ...

Sachalinese

Sieboldi

POLYPODIUM vulgare

formosum 
Each Per 10 Per 100

PRIMULA acaulis (European Primrose) ....... $30 \quad 240$

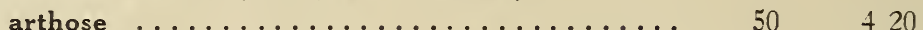

officinalis hybrida-Cowslip ........... $30 \quad 240 \quad 1800$

$\star$ veris-English Cowslip .............. $30 \quad 240 \quad 1800$

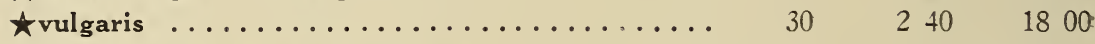

PRUNELlA Webbiana (Self-heal) $\ldots \ldots \ldots \ldots$. $30 \quad 240 \quad 1800$

PYRETHRUM roseum single ............. $30 \quad 240 \quad 1800$

VARIETIES: Coccinea (rich, reddish purple), Elsie Gertrude (pale flesh, very large), Hebe (pure white), James Kelway (vivid scarlet, very large and free), Nimrod (large and free, silvery rose), Rosy Morn (Rose-pink, very pretty).

roseum single, mixed ................ $30 \quad 240 \quad 1800$

var. atrosanguineum (Single crimson) $\ldots \ldots \ldots .30 \quad 340 \quad 1800^{\circ}$

uliginosum (Giant Daisy) ............. $30 \quad 240 \quad 1800$

RANUNCULUS acris fl. pl. (Bachelor's Button) .. $30 \quad 340 \quad 1800$

repens ......................... $25 \quad 220 \quad 15$ on

RUDBECKIA (Coneflower)

fulgida ................... 25

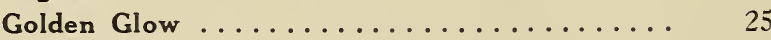

Goldstrahl ..................... 25

laciniata ..................... 25

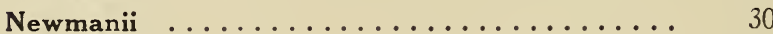

purpurea ..................... 30

Reine d'Or (Dwarf Golden Glow) ......... 30

subtomentosa ................. 30

triloba $\ldots \ldots \ldots \ldots \ldots \ldots \ldots \ldots \ldots \ldots \ldots$.

RUTA graveolens (Rue) $\ldots \ldots \ldots \ldots \ldots \ldots, 30$

SALVIA a: urea grandiflora (Meadow Sage) $\ldots . .30 \quad 30 \quad 240 \quad 1800$ argentea ..................... 30

officinalis .................. 30

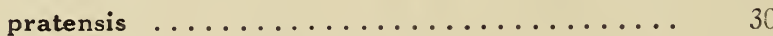

SANGUINARIA canadensis (Blood-root) $\ldots \ldots \ldots \quad 35$

SANTOLINA Chamaecyparissus ............ 30

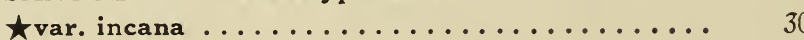

$\star$ SAPONARIA ocymoides-Soapwort ....... 30

Łofficinalis fl. pl. .................. 30

^SAXAFRAGA cordifolia-Rock foil ........ 35

$\star$ crassifolia $\ldots \ldots \ldots \ldots \ldots \ldots \ldots \ldots \ldots . \ldots \ldots$

lingulata ...................... 35

$220 \quad 1500$

$220 \quad 1500$

$220 \quad 1500$

$220 \quad 1500$

$240 \quad 1800$

$240 \quad 1800$

$240 \quad 1800$

240

$240 \quad 1800$

240

$\begin{array}{llll}30 & 40 & 1800\end{array}$

$\begin{array}{llll}30 & 240 & 1800\end{array}$

$30 \quad 240 \quad 180 \%$

$35 \quad 240 \quad 1800$

$30 \quad 240 \cdot 180 ?$

$30 \quad 240$

$\begin{array}{lll}30 & 240 & 1809\end{array}$

$\begin{array}{llll}30 & 2 & 40 & 1800\end{array}$

$35 \quad 300 \quad 2007$

$30 \quad 240 \quad 1800$

$35300 \quad 2001$

McNabiana ..................... $30 \quad 2$ th 18 on 
Each

SCABIOSA Caucasica

var. alba

Japonica

Pennsylvanicum

SEDUM (stone crop)

tacre (Golden Moss)

$\star$ album

$\star$ anglican

$\star$ Ewersi

$\star$ kamtschaticum

$\star$ Maxamwesii

$\star$ maximum

$\star$ var. atropurpureum

$\star$ var. Stahli

$\star$ Sieboldi

$\star$ spectabile (Brilliant Stone Crop)

$\star$ var. Brillian

$\star$ var. atropurpurea

$\star$ stolonifera

SEMPERVIVUM arachnoideum

tectorum

SENECIO clivorum

pulcher

Vilsonianus

Veitchianus

SHASTA DAISY - See Chrysanthemum leucanthe mum

SIDALCEA candida-Indian Mallow ......... 30

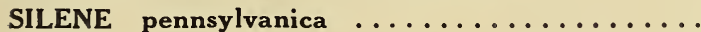

SILPHIUM perfoliatum-Compass Plant ....... laciniatum

SOLIDAGO Canadensis (Golden Rod)

rigidus

rugosa

sempervirens

SPIRAEA astilboides

exinia

$\star$ filipendula

$\star$ var. flore plena

gigantea

japonica

lobata Venusta

multiflora
Per 10 Per 100

$35 \quad 300$

$30 \quad 240$

$30 \quad 240$

$30 \quad 240$

1800

30

30

30

30

30

30

30

30

30 
SPIREA - continued

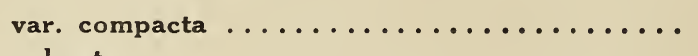

palmata $\ldots \ldots \ldots \ldots \ldots \ldots \ldots \ldots \ldots$

var. alba $\ldots \ldots \ldots \ldots \ldots \ldots \ldots \ldots \ldots \ldots$

var. elegans $\ldots \ldots \ldots \ldots \ldots \ldots \ldots \ldots \ldots$

ulmaria fl. pl. ................ 30

Each Per 10 Per 100

STACHYS $\star$ Betonica superba (Woundwort) ... $\quad 30$

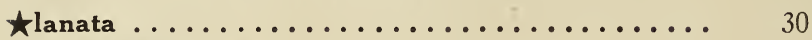

30

240

1800

$\begin{array}{lll}30 & 240\end{array}$

$30 \quad 240$

1800

$25 \quad 220 \quad 1500$

$30 \quad 240 \quad 1800$

rosa grandiflora .................... 30
$\star$ STATICE latifolia (Sea Lavender) ......... 30

$240 \quad 1800$

$240 \quad 1800$

tatarica ..................... 30

$240 \quad 1800$

240

1800

STOKESIA cyanea-Stokes' Aster .......... 30

240

var. alba ...................

var. rosea $\ldots \ldots \ldots \ldots \ldots \ldots \ldots \ldots \ldots \ldots$

30

30

240

1800

TEUCRIUM Chamaedrys (Wall Germander) .....

240

240

$\star$ THALICTRUM adiantifolium (Meadow Rue) .

240

aquilegifolium

30

240

1800

var. purpureum

dypterocarpum $\ldots \ldots \ldots \ldots \ldots \ldots \ldots \ldots$

plolyganum

240

1800

35

30

300

2400

THERMOPSIS caroliniana $\ldots \ldots \ldots \ldots \ldots \ldots \ldots$

mollis

240

1800

$\star$ THYMUS vulgaris - Thyme ............

$\star$ serphyllum album ................

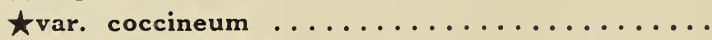

var. lanuginosus .

240

1800

TIARELLA cordifolia-Mitewort ..........

TRILLIUM grandiflora-Wood Lily .........

Uvaria grandiflora $\ldots \ldots \ldots \ldots \ldots \ldots \ldots \ldots$

TROLLIUS Asiaticus (Globe Flower)

Asiaticus fl. pl.

Europeaus

Fortunei fl. pl.

Japonicus fl. pl.

var. napelliflorum 
Each Per 10 Per 100

VALERIANA officinalis $\ldots \ldots \ldots \ldots \ldots \ldots \ldots \ldots .30 \quad 240$

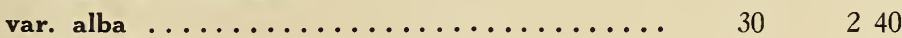

var. rubra ................... $30 \quad 240$

1800

VERBASCUM Olympicum ............ 30

240

$180 \mathrm{G}$

pannosum

240

$180 \mathrm{u}$

VERBENA Hestata

240

1800

VERNONIA Arkansana (Iron Weed) ................... 30

240 noveboracensis

240

1800

VERONICA $\star$ amethystina (Speedwell)

240

1800

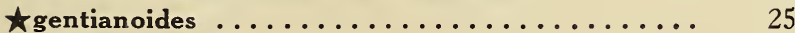

220

1500

longifolia alba

240

1800

longifolia subsessilis

300

2700

$\star$ repens

240

rosea

240

$\star$ incana

$\star$ rupestris

var. alba

spicata.

240

1800

var. alba

220

1500

Virginica

240

1800

30

220

1500

VINCA major

240

1800

minor-Periwinkle or Trailing Myrtle, $\$ 100.00$ per M. (from pots) ............. 25

var. aurea .................... 30

220

1500

var. flore plena

240

var. rosea

220

var. variegata

220

25

250

VINCETOXICUM Japonicum ........... 30

240

1800

VIOLA canadensis (Violets)

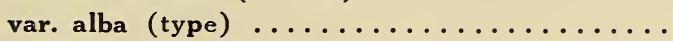

var. atropurpurea (type) $\ldots \ldots \ldots \ldots \ldots \ldots$

var. G. Wermig

\section{Hybrids-Tufted Pansies}

Varieties: Admiration, Blue Perfection, Lutea, Mauve Queen, Papilio, Purple Queen, White

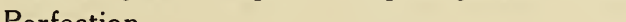

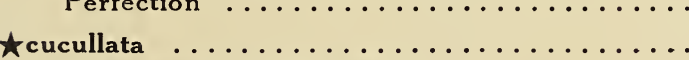

Odorata var. Single Russian ........... pedata

YUCCA filamentosa (Adams' Needle) 


\section{A Word About Transportation}

\section{IN NO DEPARTMENT OF ITS USEFULNESS HAS THE AUTO} TRUCK PROVED ITSELF OF GREATER VALUE THAN

\section{IN THE DELIVERY OF NURSERY STOCK}

FIRST-Because within a range of one hundred miles from our nurseries, it can travel the distance so quickly that stock arrives as fresh as when taken from the nursery rows.

SECONDLY-Because the Truck lands the stock on the grounds where it is to be planted, thus saving the bother and expense of trucking and unpacking.

THIRDLY-Because it can be delivered at less expense than would be the boxing, freight and trucking if charges sent by freight in boxes, providing there is stock sufficient to make a respectable load for a truck.

The charges are made according to the distance travelled and the size of the truck used.

REMEMBER that we have a siding at our packing house where we have every facility for handling car lots for long distances with promptness and efficiency.

REMEMBER also that we are here to serve. Command and see how well we can execute your orders.

\section{Location of Nurseries}

The Bay State Nurseries are located in North Abington, Mass., 18 miles South of Boston, on the Plymouth Division of the N. Y., N. H. \& H. R. R.half way from Boston to Plymouth. Trains leave the South Station at frequent intervals during the day. Visitors are always welcome. Our office is ten minutes' walk from the station. If notified, we gladly meet visitors at the station and take them about the nurseries.

To reach us from Boston by motor, go to Quincy, then proceed directly South through Weymouth and South Weymouth until you see our sign at the fork of a road, turn to the left and you cannot miss our office one-half mile farther on. We are just off the road which goes to Middleboro and the Cape.

We are NOT OPEN FOR BUSINESS ON SUNDAY. 
MEMORANDUM 


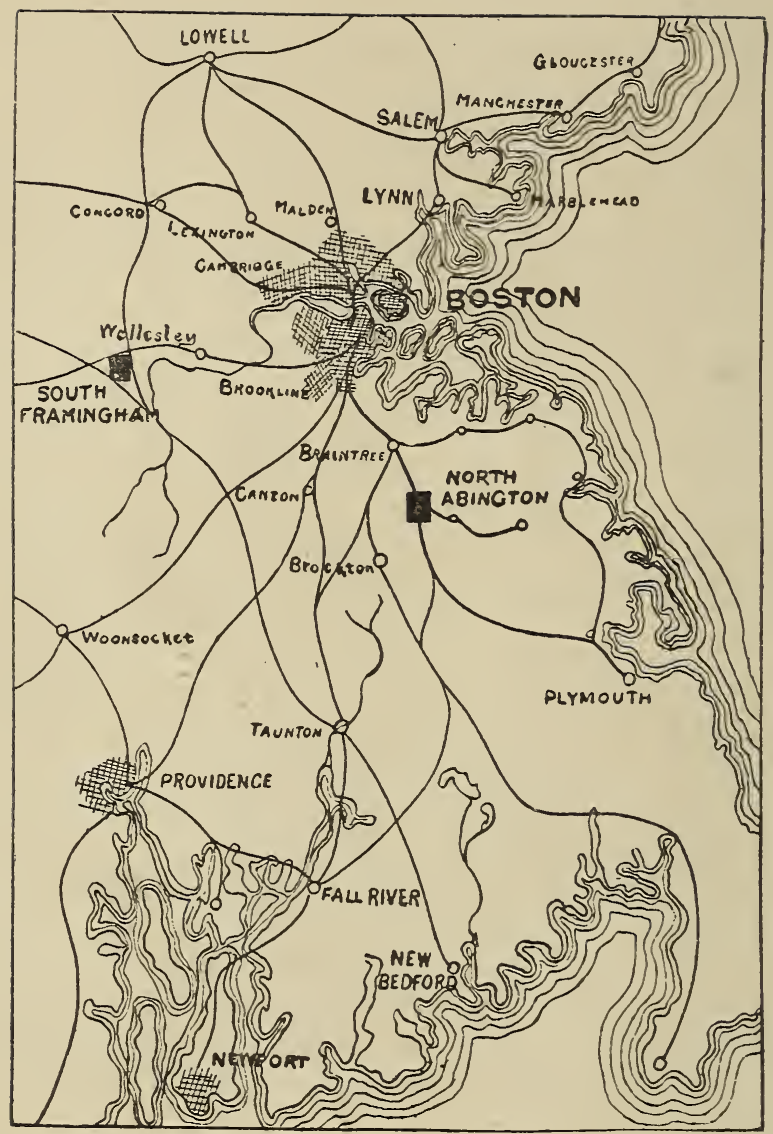

Our Nurseries are located 18 miles south of Boston on the Plymouth Division of the N. Y., N. H. and H. Railroad.

THE BAY STATE NURSERIES WINDSOR H. WYMAN, PROPR. NORTH ABINGTON MASS. 